\title{
انماط العلاقة التفاعلية بين السلطة الاتحادية ومجالس المحافظات غير المنتظمة بإقليم
}

م.م.علي عباس عبيد م.د. فر اس كوركيس عزيز

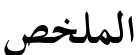
تقوم السلطة المحلية المتمثلة بمجلس المحافظة والوحدات الادارية التابعه لها بمهام تشريعية ورقابية تتمثل في ادارة المرافق العامه المحلية والاشراف عليها وفق ما تنص لهص عليه القوانين النافذة ، ويعد موضوع العلاقة التفاعلية بين السلطة الاتحادية ومجالس لتسليه المحافظات غير المنتظمة بإقليم من اهم الاشكاليات التي رافقت نشوء وتطبيق النظام

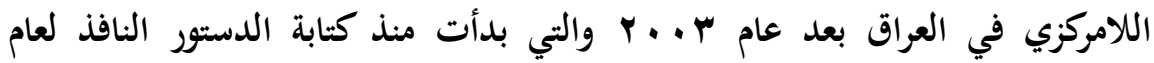

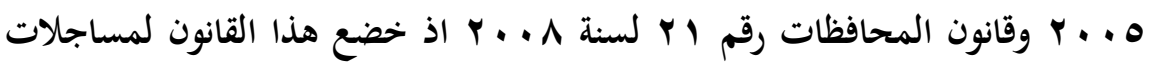
سياسية ادت في النهاية الى ظهورة بهذه الصورة التوافقية وكان ضعف الصياغة التشريعية احد اسباب ذلك في تشريع قوانين غير دقيقة ترتب عليها تحديد شكل العلاقة في ثلاث محاور وهي (الرقابة -التعاون - التداخل ) في الاختصاصات ولئ والصلاحيات الممنوحه بموجب الدستور وقانون المحافظات النافذين، فالرقابة تعد الوسيلة والممارسة

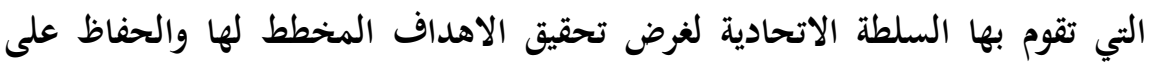
وحدة الدولة السياسية والقانونية اما التعاون يمثل الوسيلة الامثل لتحقيق اهداف رسم

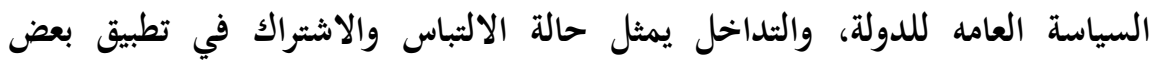
الاختصاصات المتعلقة بعمل السلطة الاتحادية والسلطة المحلية.

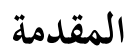

تمثـل الحكومـات المحليسة التجسـيد الحقيقـي لنظـام اللامركزيسة الاداريسة التي تعسد

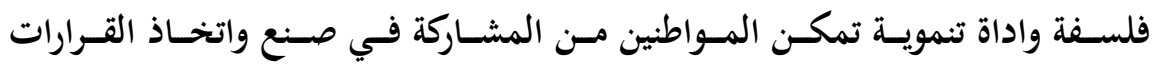

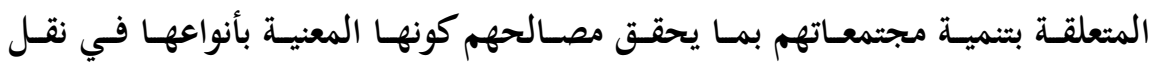


السـلطات والصــلاحيات مــن المســتويات المركزيسـة الاعلــى الــى المســتويات

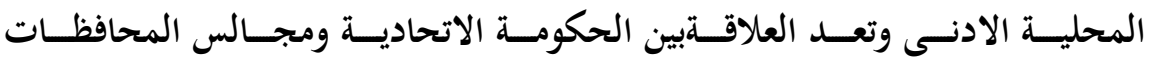

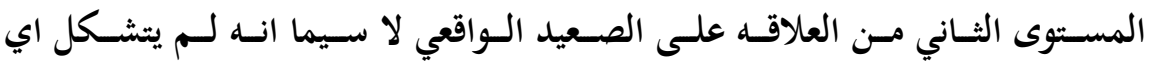
اقلـيم اخـر في العـراق سـوى اقلـيم كردسـتان منــ تبنـي خيـار الفيدراليـة في العـراق

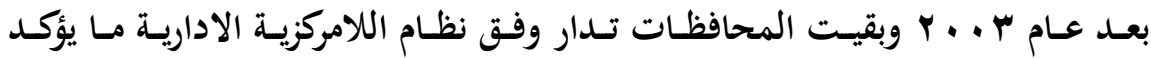
علـى ان هنــاك علاقـهـ بــين السـلطة الاتحاديسـة وهـذه المجــالس فـي ظـل وجـود

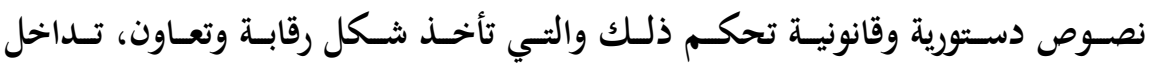
وما هو مستقبل هذه العلاقه وكيف سيكون ؟ اهمية البحث تـأتي اهميـة البحــث في ان العلاقــة بـين السـلطة الاتحاديــة ومجــالس المحافظـات

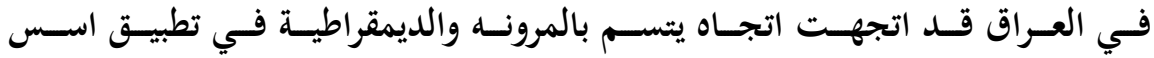

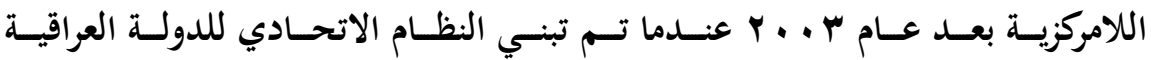

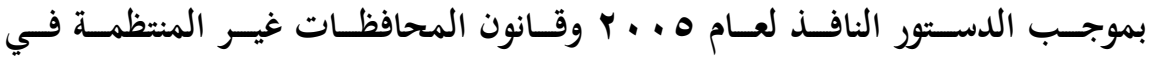

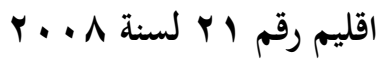
اشكالية البحث

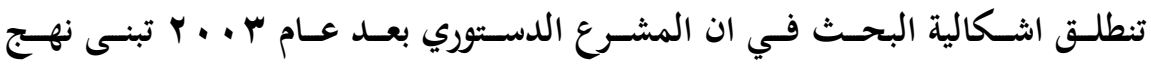

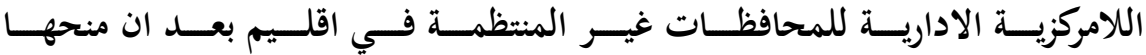

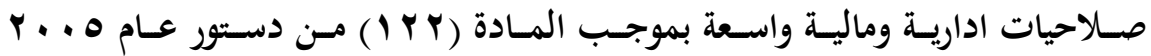

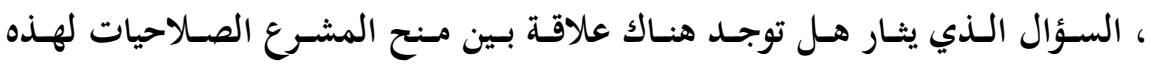

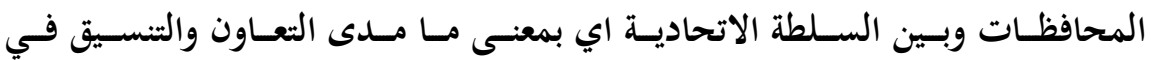

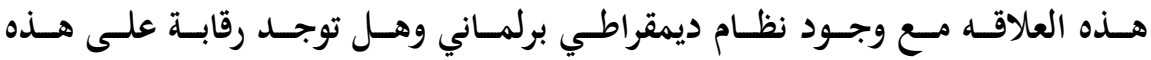

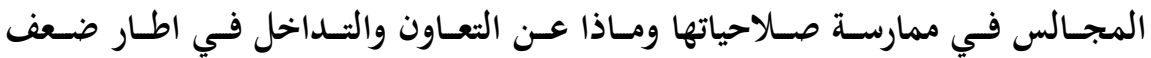

النصوص الدستورية والقانونية ؟ فرضية البحث 
ان الواقـع العملـي لمجـالس المحافظــات فـي ظـل التشـريعات التـي نظمـت عملهـا

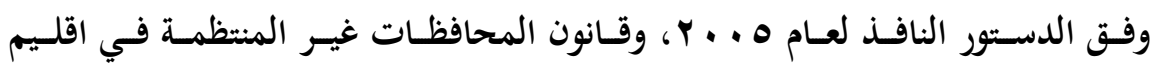

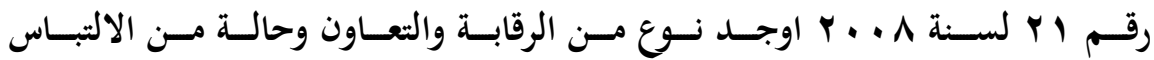

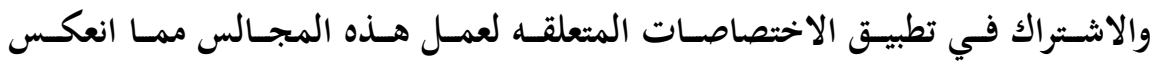

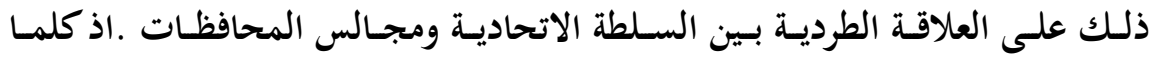
قويــت العلاقـة كلمـا ازدادت فاعليسة تطبيـق اسـس النظـام اللامركـزي بشكله السـليم

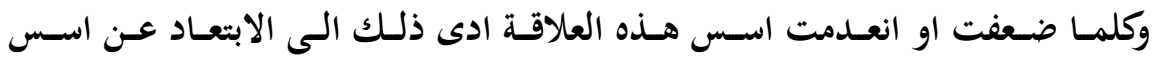

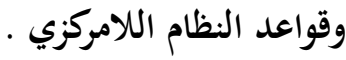
منهجية البحث

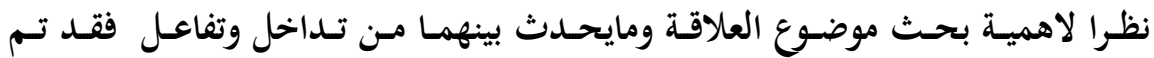

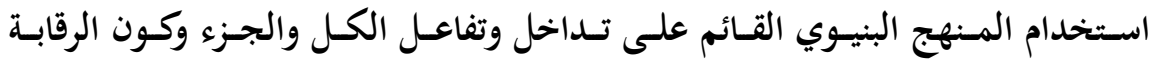

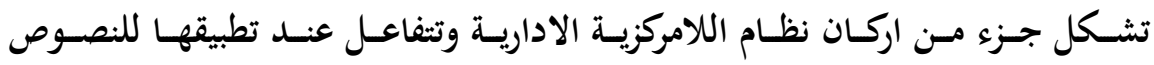

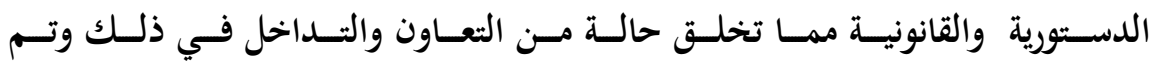

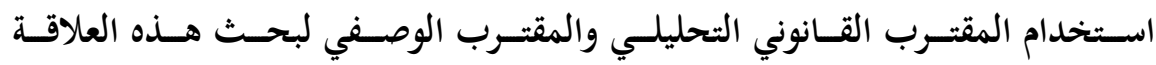

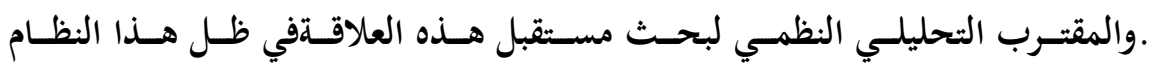

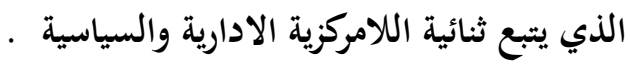
هيكلية البحث

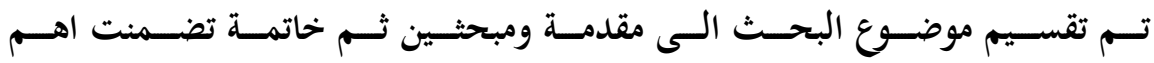
الاستنتاجات :المبحث الاول : تناولنا انماط علاقات التفاعل وسيكون في ثلاث مطالب المطلب الاول : نمط علاقة رقابي المطلب الثاني :نمط علاقة تعاوني المطلب الثالث:نمط علاقتتداخلي المبحث الثاني : نتناول فيه مستقبل العلاقة التفاعلية وفي مطلبين : 
المطلب الاول : تزايد قوة الاطراف المحلية. المطلب الثاني : تزايد قوة مركز السلطة الاتحادية

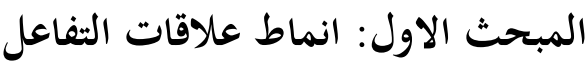

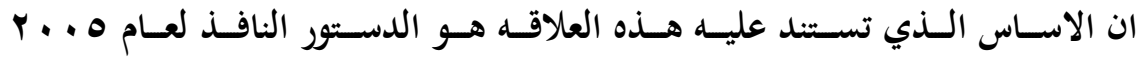
والــذي يمثـل انتقالـه حقيقيسه نحسو تطبيـق الديمقراطيـة وتبنيسه لنظــام اللامركزيسة

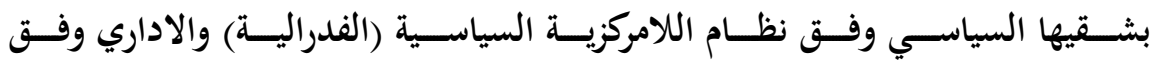

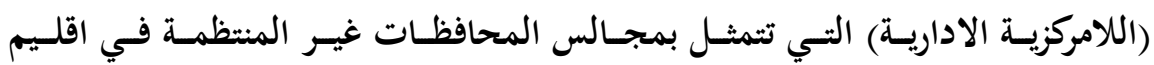
والتسي نظمها الدستور في المسادة (Y Y I ) منسه وبتفصسيل اكثر وضسوحا لمعالمها

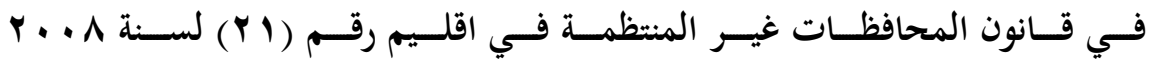

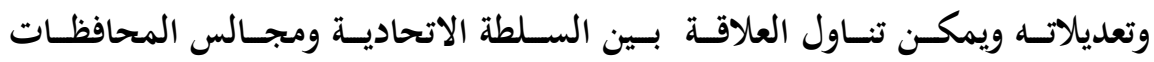
وفق ثلاث مطالب وكالاتي:المطلب الاول :- نمط علاقة رقابي المطلب الثاني :- نمط علاقة تعاوني : المط علي

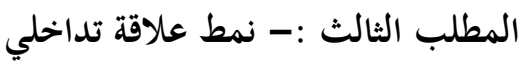
المطلب الاول: نمط علاقة الرقابي

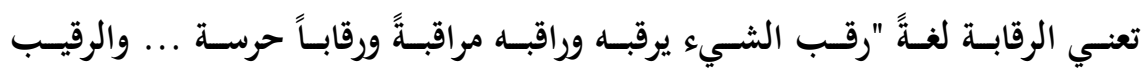

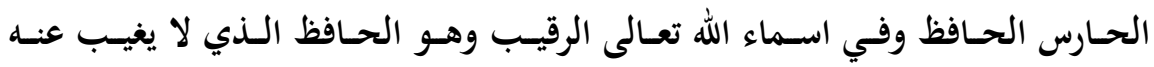

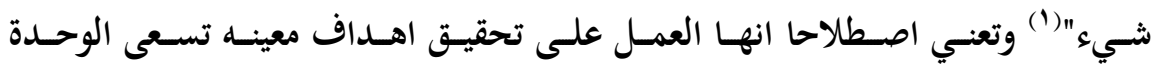

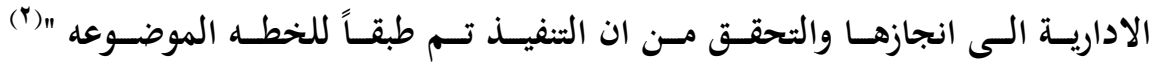

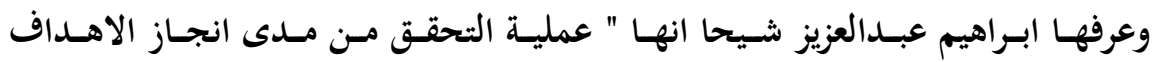
المرسـومة بكفايسه والكشـف عـن معوقـات تحقيقها والعمـل على تـذليلها في أقصـر

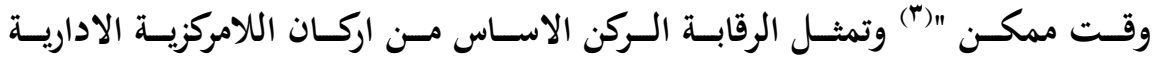

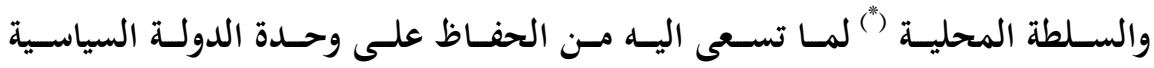

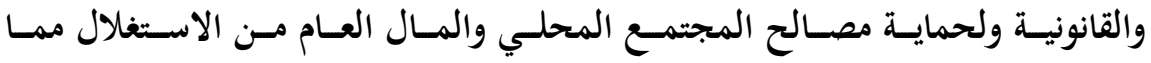




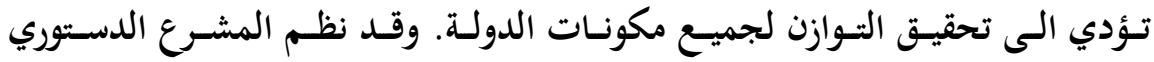

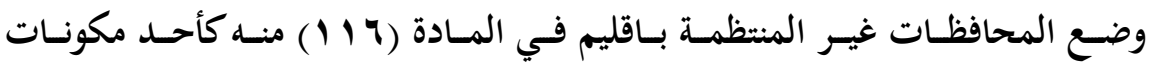

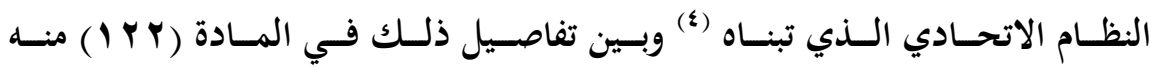

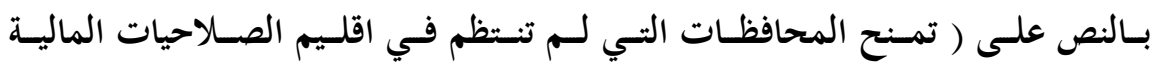

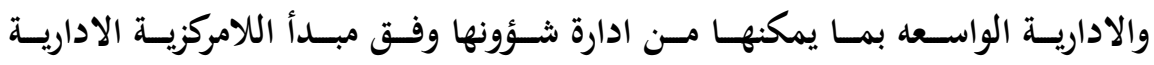
ويـنم ذلك بقـانون ـ وتـم صـدور قـانون المحافظـات غيـر المنتظمـة في اقلـم رقـم

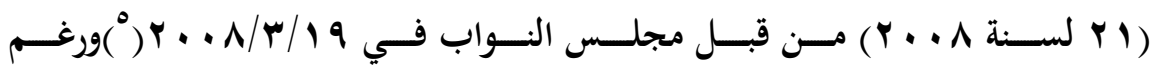

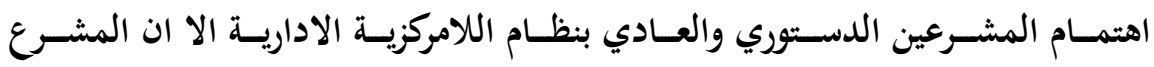

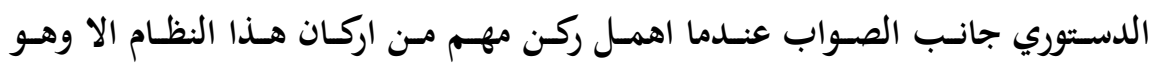

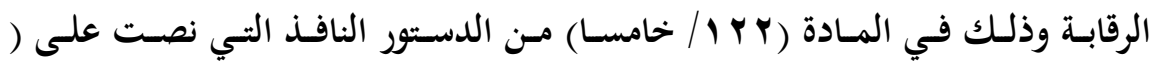

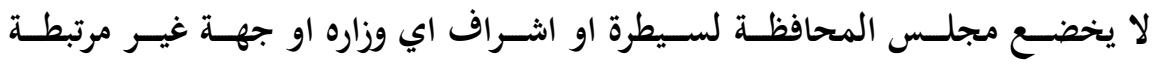

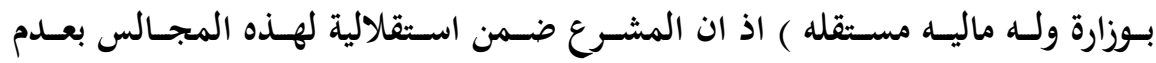

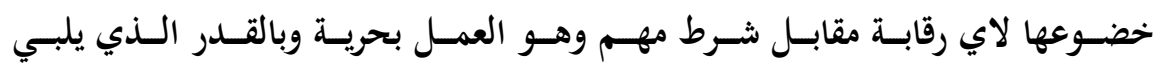

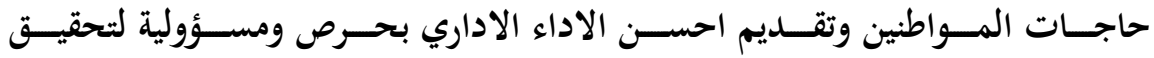

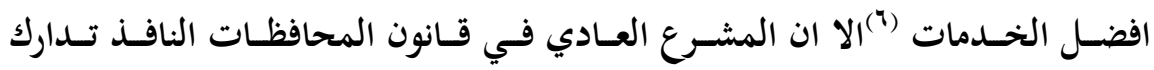
ذلك الامـر بخضـوع مجلـس المحافظـة والمجـالس المحليـة لرقابـة مجلـس النـواب

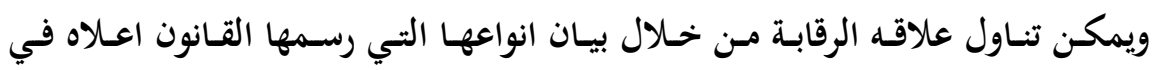

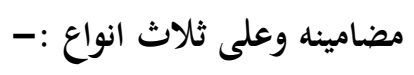

اولا-الرقابـة السياسـية :- وهـي الرقابـة التـي تمـارس مـن اعلـى سـلطة سياسـية

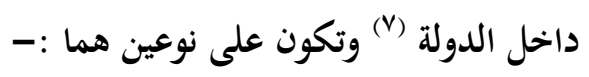

1-الرقابة التشريعية (البرلمانية )

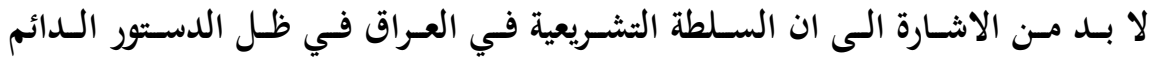

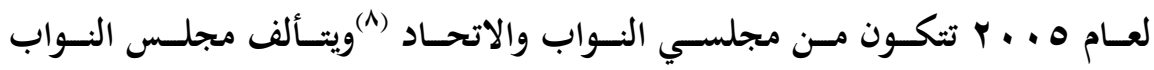

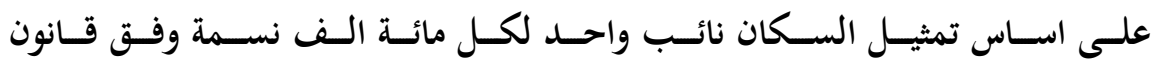




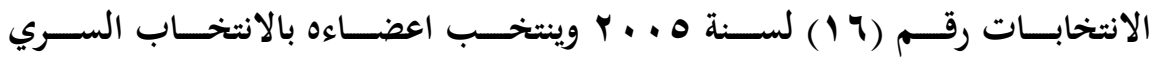

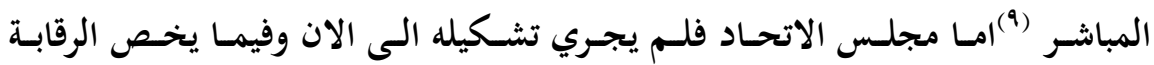

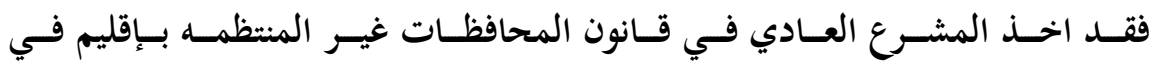

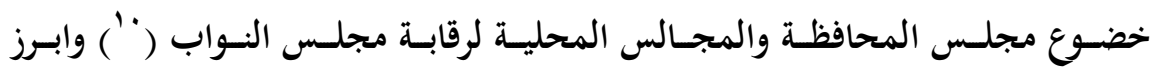

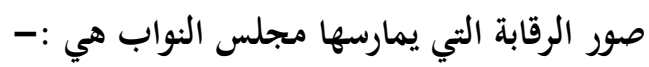
أ-اقالة المحافظ وتستم اقالــة المحسافظ بالأغلبيـة المطلقـة لمجلـس النـواب بنساء علـى اقتـراح رئسيس

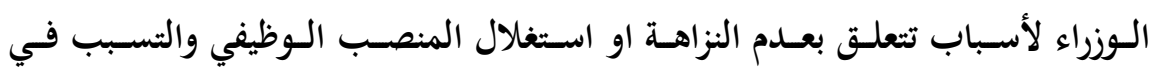

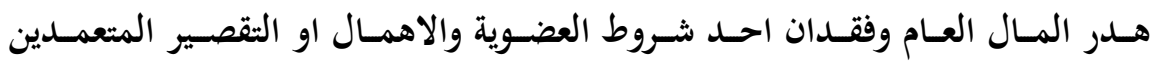

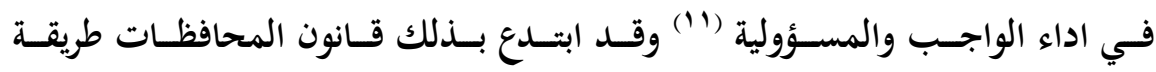

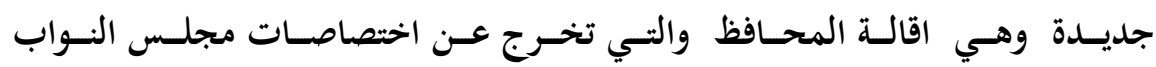

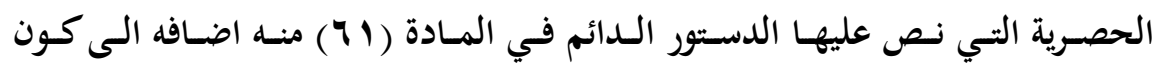

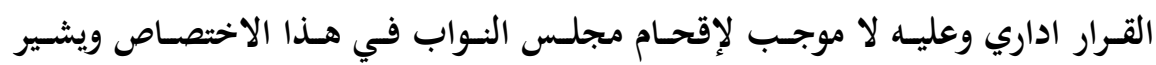

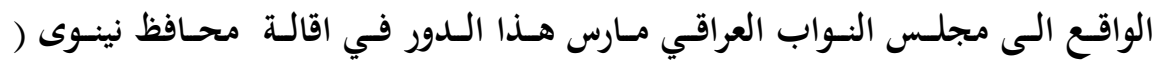

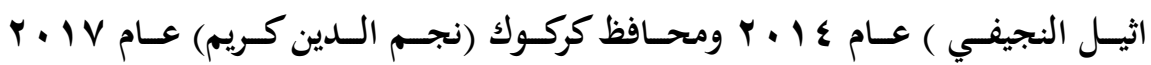

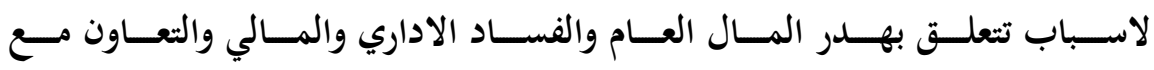

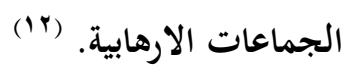
ب-حل مجلس المحافظة

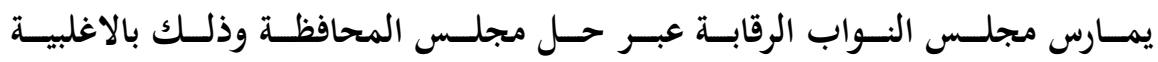

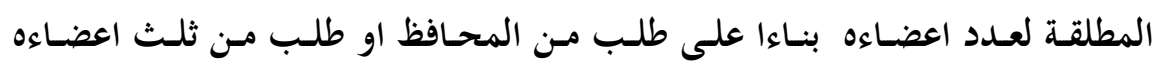

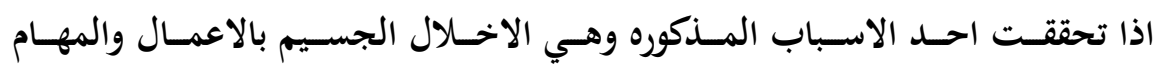

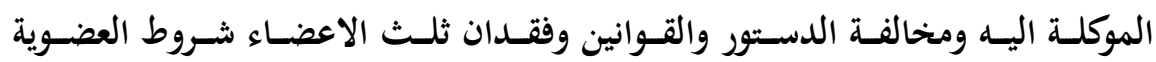

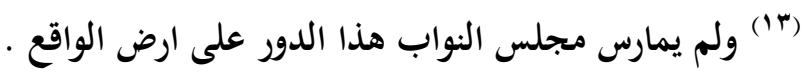


ج-تحديسـد اختصاصـات المجــالس المحليـة والغاؤهـا :- بإمكــان مجلـس النـواب

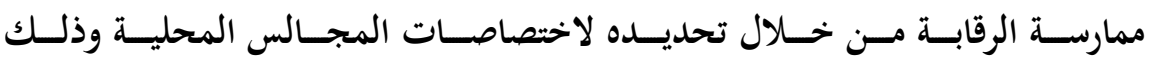

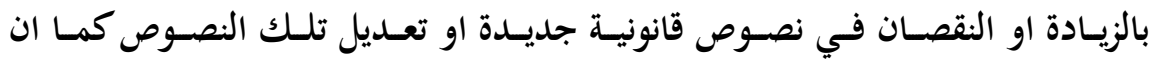

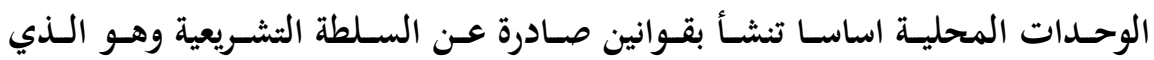

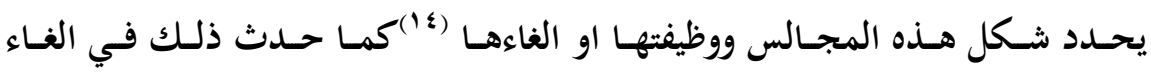

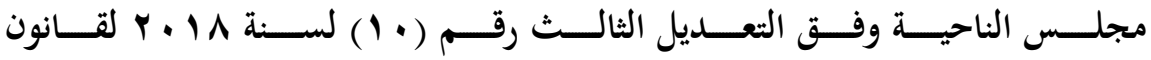

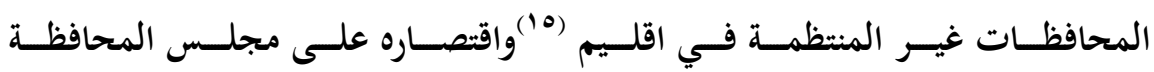

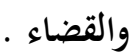

د-مناقشة الموازنة العامة للدولة

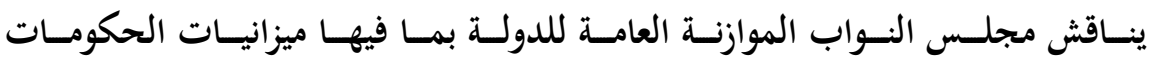
المحليـة فيكـون لكـل محافظــة موازنسة محليسة خاصسة بهـا تشــمل جميـع الايسرادات

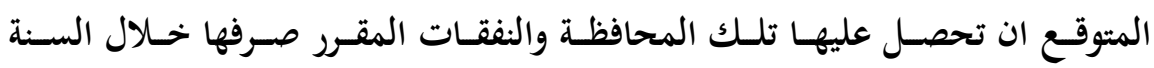
الماليـة والتي ترفع الى وزارة الماليـة في الحكومـة الاتحاديـة لتوحيـدها مـع الموازنــة

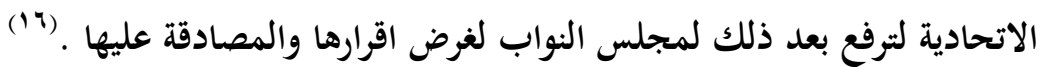
هـ-الاعتراض على القرارات التي تصدر من الحكومات المحلية

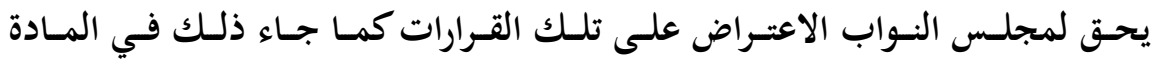

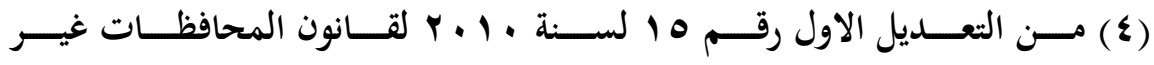

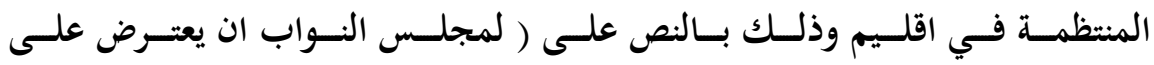
القــرارات الصـادرة مـن مجلـس المحافظــة اذا كانــت مخحالفــة للدسـتور والقــوانين

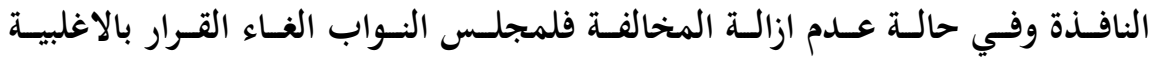

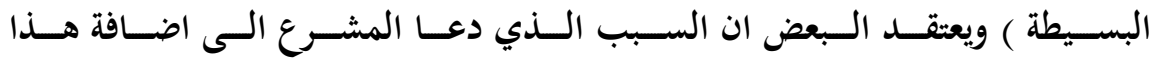
الاختصـاص الرقـابي يعـود الـى ان وسـيلة حسل مجلـس المحافظــة تمثـل وسـيلة

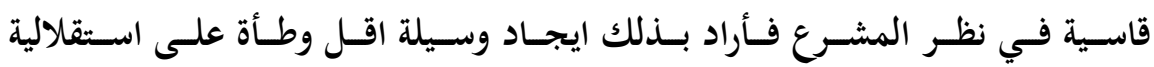

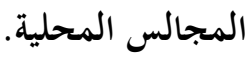


r- r الرقابة الشعبية

تمــارس هـذه الرقابـة مـن قبـل الاحسزاب السياسـية التـي تشـترك في رسـم السياسـة

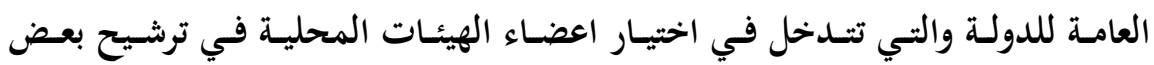

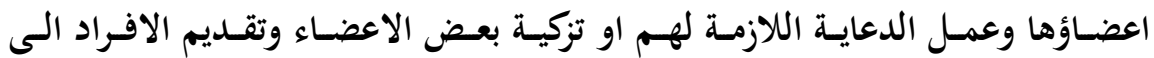

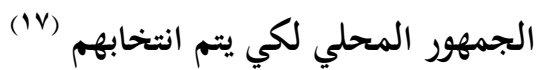
وكسذلك تمـارس هـذه الرقابـة مـن خـلال هيئسة النساخبين اذ تنصــب علـى اعضــاء المجــالس المحليـة باعتبـارهم منتخبـين مـن ابنساء الوحسـات الاداريسة ولهـم صـلة مباشـرة معهـم ومسن ثـم اي تقصسير في ادائهـم سـينعكس سـلبا عنسـ ترشـحهم مـرة

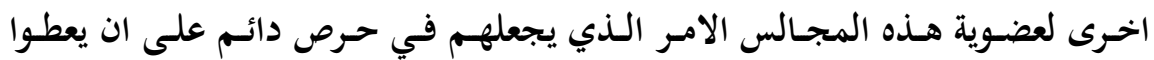

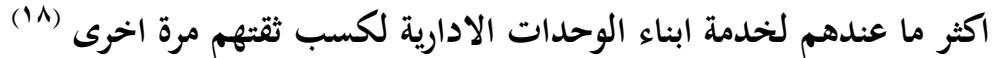

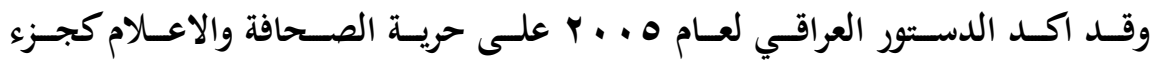

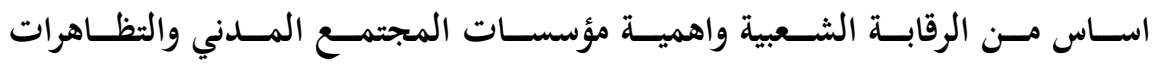

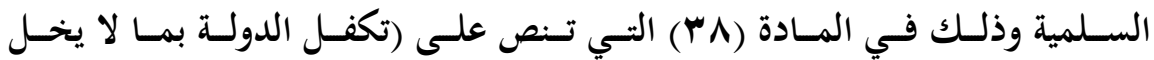

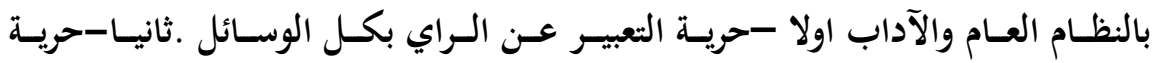

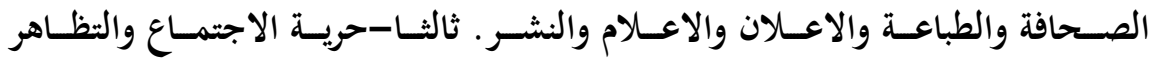

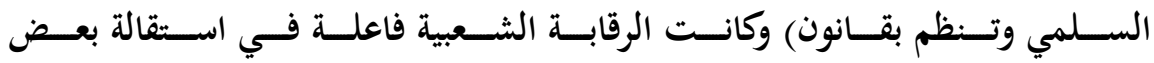

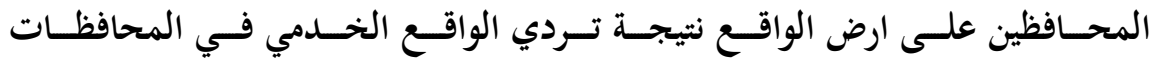

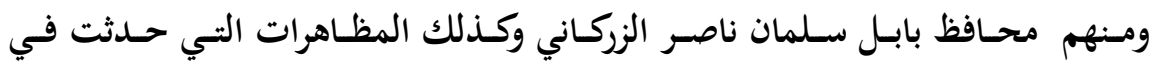

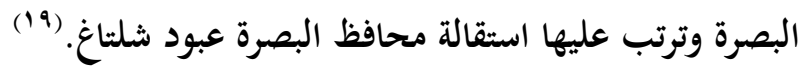
ثانيا - الرقابة الادارية مارسـت الحكومسة الاتحاديـة رقابتهـا علـى الهيئسات المحليـة رغــم اقـرار الدسـتور

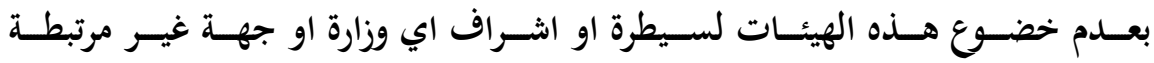

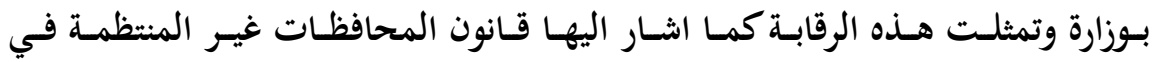

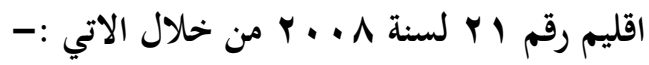




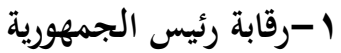

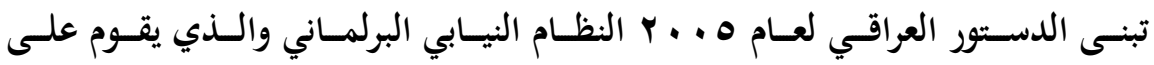

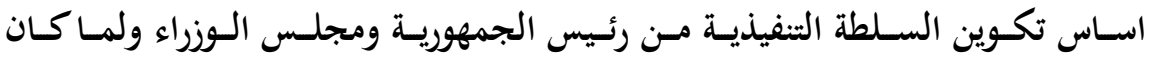

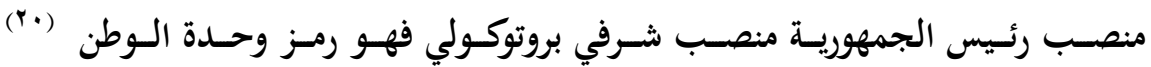

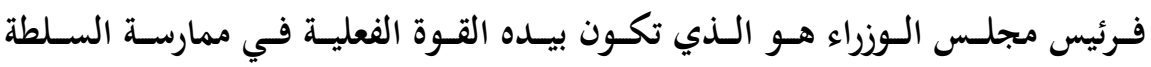

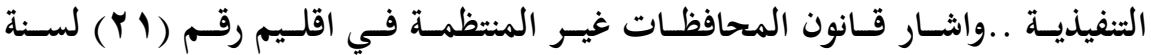

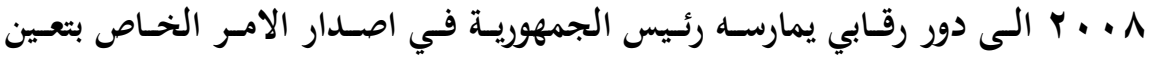

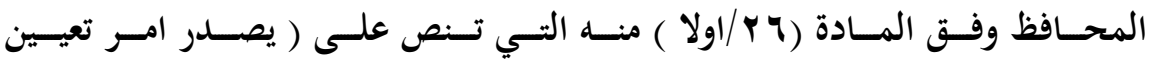

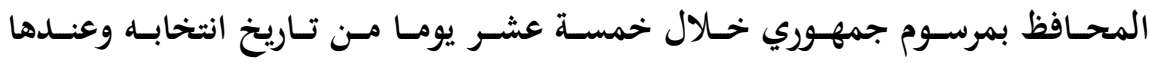

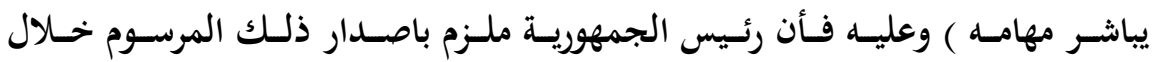

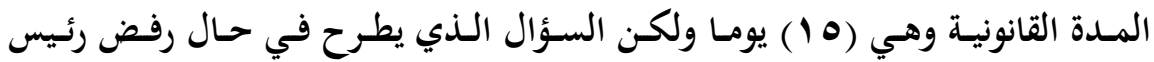

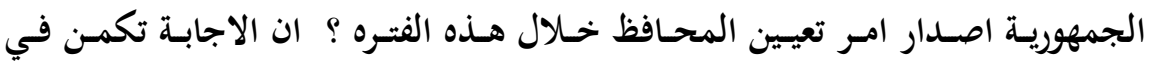

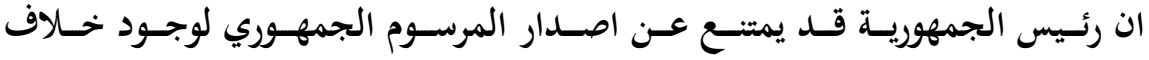

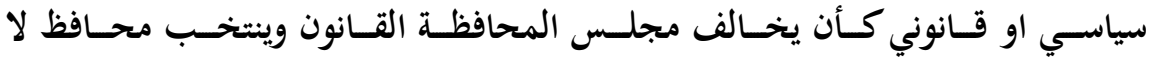
تتـوفر فيسه الشـروط القانونيـة المطلوبـه فيقـوم رئسيس الجمهوريسة بـنقض امـر تعيسين

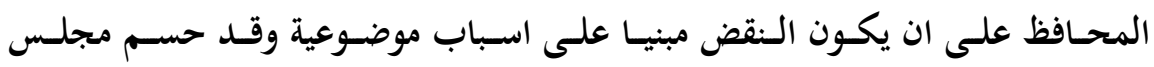

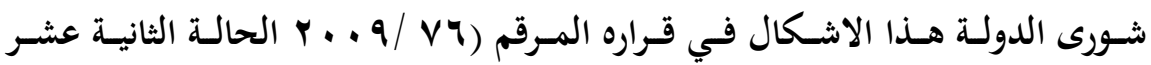

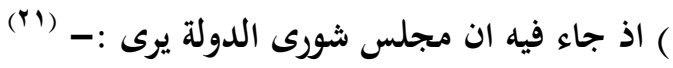
-ان انتخــاب مجلـس المحافظـة لمحسافظ جديسـد لا تتـوفر فيسه الشـروط القانونيـة

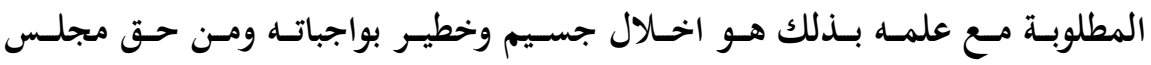
الرئاسة ان يرفض التعيين اذا تحقق ان الشروط القانونية غير مستوفيه . -ان مجلـس الرئاسـة ملـزم بتطبيـق احكــام القـانون ولا يجـوز للمحسـافظ ان يباشــر عمله قبل صدور المرسوم الجمهوري بتعيينه. 
-ان المحسـافظ المنتهيـهـ ولايتـهـه يسـتمر بعملـه كمحسـافظ لحسين مباشـرة المحسـافظ الجديد.

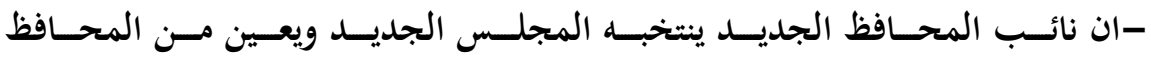
الجديد ولا يحق للمحافظ المنتهيه ولايته تعيين نائب محافظ جديد .

Y - بابة رئيس مجلس الوزراء

يعد رئيس مجلس الوزراء المسؤول التنفيذي المباشر عن السياسة العامة للدولة والقائد العام للقوات المسلحة (rr) ويمارس رئيس مجلس الوزراء رقابة غير مباشرة اشار اليها قانون المحافظات النافذ وتتمثل في اقتراح اقالة المحافظ كما نصت على ذلك المادة (

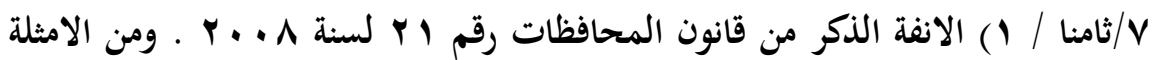
الواقعية اقتراح رئيس مجلس الوزراء د. حيدر العبادي اقالة محافظ كركوك نجم الدين كريم · وتظهر ايضا رقابة مجلس الوزراء من خلال اعفاء اصحاب المناصب العليا في المحافظه وهم المدراء العامون ومدراء الدوائر ورؤساء الاجهزة الامنية في حدود المحافظة وذلك بناء على اقتراح الوزير المتحص (Tr) وكذلك من خلال الهيئة العليا للتنسيق بين المحافظات اذ نصت المادة (0 ع -اولا) على ان تؤسس هيئة تسمى الهيئة العليا للتنسيق بين المحافظات برئاسة رئيس مجلس الوزراء وعضوية وزراء(البلديات والاشغال العامه، الاعمار والاسكان، العمل والشؤون الاجتماعية ، التربية ، الصحة ، التخطيط، الزراعة ، المالية ، الرياضة والثباب ) ووزير الدولة لشؤون المحافظات والمحافظين ورؤساء مجالس المحافظات اذ تتولى التنسيق بين المحافظات ومعالجة المشكلات والمعوقات التي تواجهها .. ويمسارس الـوزراء دورهـم الرقابي في اختيـار شـخص مـن بسين ثلاثنـة اشـخاص لشـفل احسد المناصـب العليـا في المحافظــة كالمــراء العـاميين ورؤسـاء الـدوائر والاجهـزة الامنيـة ويحـق للـوزير المخـتص كـذلك ان يقــدم اقتراحسـا الـى مجلـس الـوزراء بإقالـة 
احســ الاشــخاص مـن اصـحاب المناصـب العليـا وبموافقـة مجلـس الــوزراء فـي ذلك. (广\&)

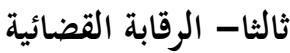
تتكـون السـلطة القضـائية في العـراق وفق الدسـتور العراقي لعـام ه ـ . F مـن مجلـس القضــاء الاعلـى والمحكمــة الاتحاديسة العليـا ومحكمــة التميـز الاتحاديسة وجهـاز الادعـاء العـام وهيئسة الاشــاف القضـائي والمحساكم الاتحاديـة الاخــى التـي

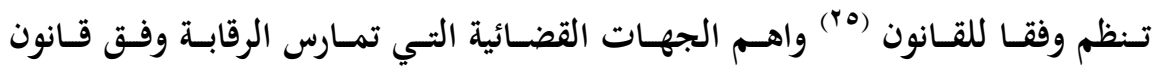

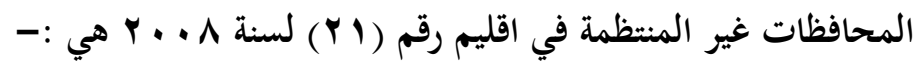
1- المحكمة الاتحادية العليا

تشـكلت هـذه المحكمــة اسـتنادا السى المــادة (ع ع،بـ) مــن قـانون ادارة

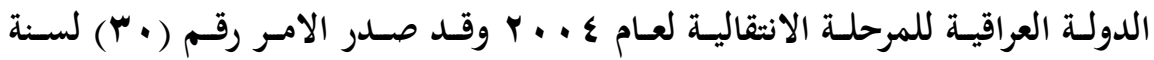

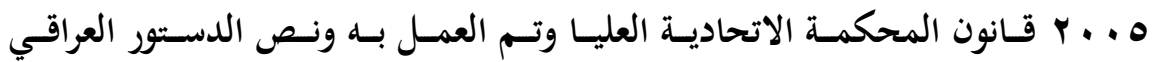

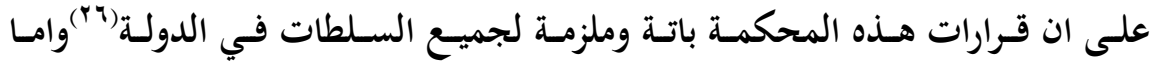
الرقابة التي تمارسها هذه المحكمة هي :-

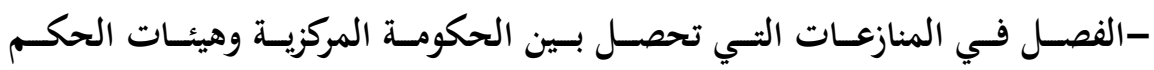

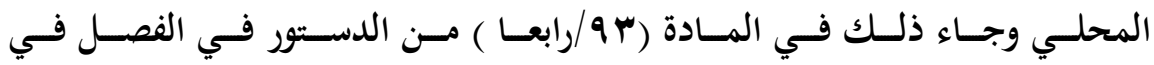

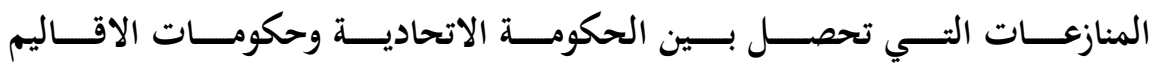
والمحافظات والبلديات والادارات المحلية . -النظـر في الطعـن بقـرار حسل المجـالس المحليـة اذ اشـارت المـادة (• ب/ثالثـا) مـن القـانون الى (للمجلـس المنحسل او لثلــث اعضــائه ان يعتـرض علـى قـرار الحـل

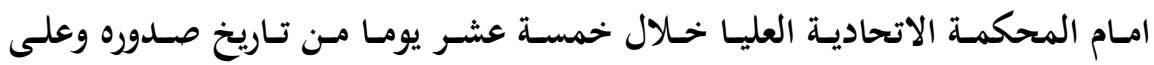
المحكمة ان تبت في الاعتراض خلال ثلاثون يوما من تاريخ تسجيله لديها . )

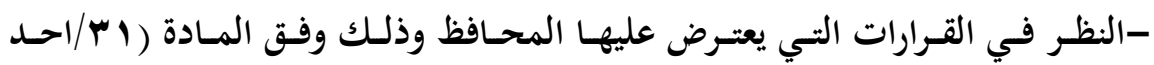

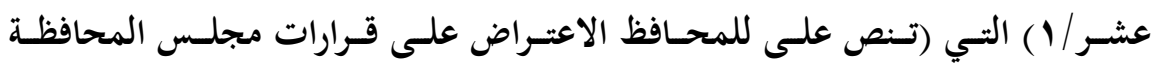


او المجلـس المحلـي فـي حسال مخحالفـة الدسـتور والقـوانين النافــه او اذا لـم تكـــ من اختصاصات المجلس او للخطة العامة للحكومة الاتحادية او للموازنة) . r-رقابة القضاء الاداري والعادي

تعسد هـذه المحكمـة جهـاز اداري ينظـر في الطعـون والقــارات الاداريــة وهـو

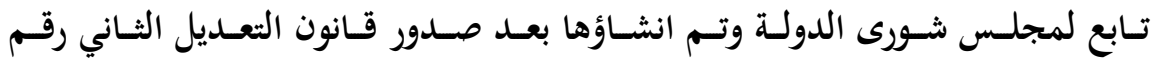

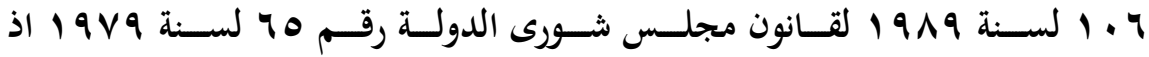

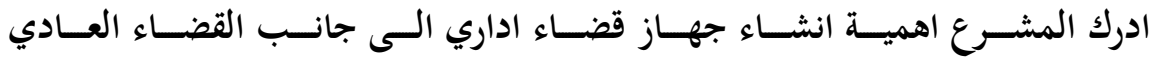

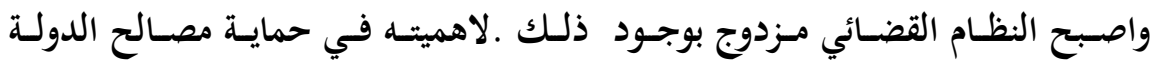

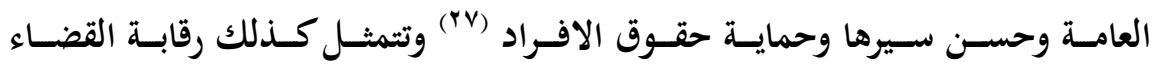

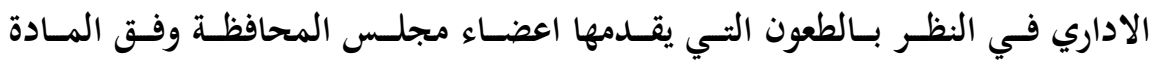

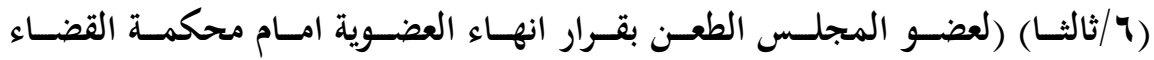
الاداري خلال · · يوما من تاريخ تبلغه بالقرار )

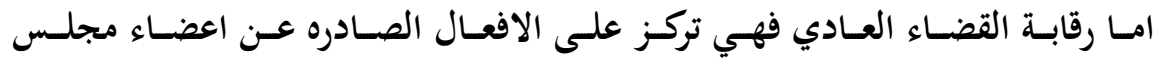

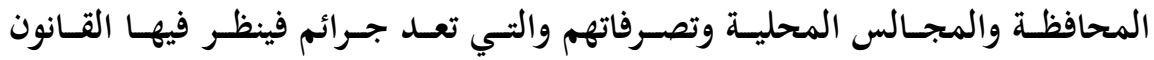

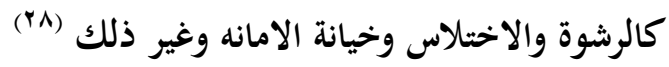
رابعا - رقابة الهيئات المستقلة اوجـــ المشـرع العراقي اجهـزة رقابيـة متخصصـه اختصاصـا دقيقـا في الرقابــة على هيئسات الحكــم المحلـي ومكافحــة الفســاد المـالي والاداري بكافـة اشـكاله

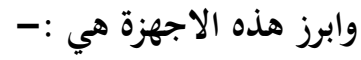
ا-ديوان الرقابة المالية يتـولى ديـوان الرقابـة الماليـة ممارسـة الرقابـة الماليـة والاداريـة اسـتنادا الـى

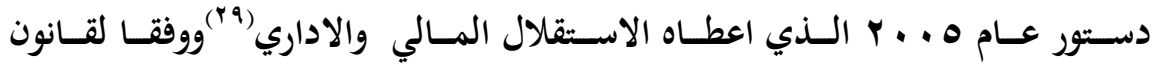

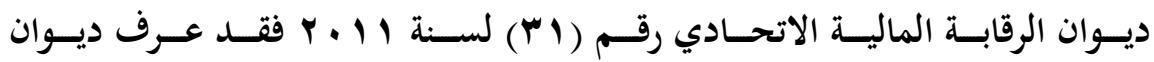

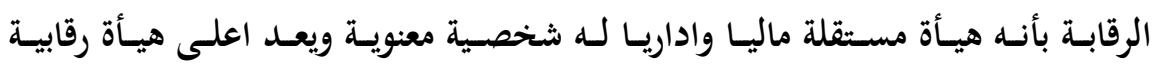


وماليسة ويـرتبط بعمـل مجلـس النسواب ويمثلـه رئسيس الـديوان او مـن يخولهه (·") وامـا

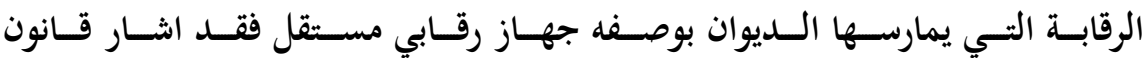

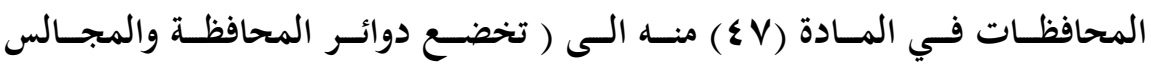

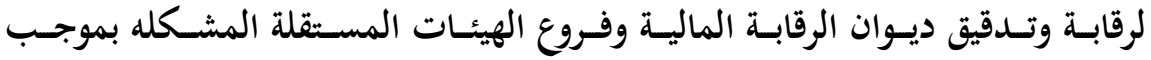

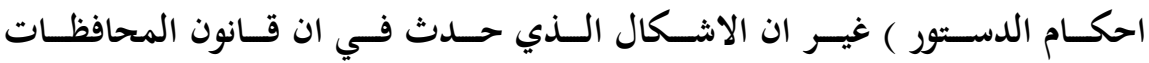

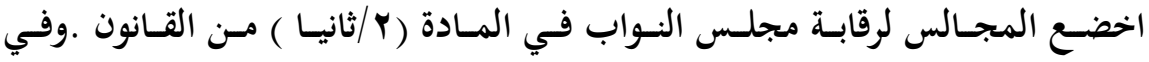

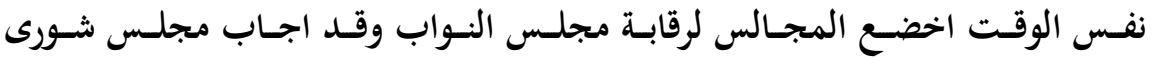
الدولـة عـن ذلـك بـأن رقابـة مجلـس النـواب علـى مجــالس المحافظـات لا تتعـارض

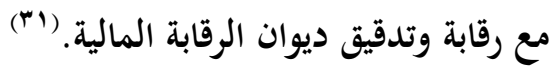
r ب - بابة هيأة النزاهة

وهـي جهــاز حكـومي مسـتقل تتسولى التحقيسق فـي قضــايا الفســاد وتلقـي

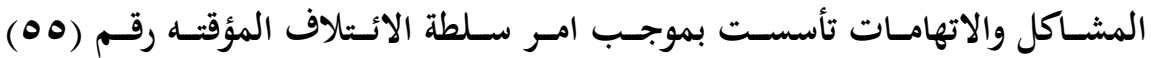

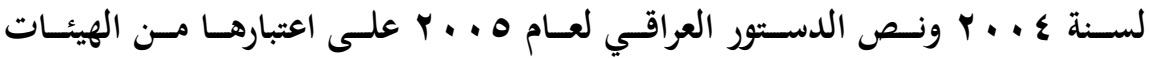
المسـتقلة وفـق المـادة ب • 1 التـي نصـت علـى ( تعـد المفوضسية العليـا لحقـوق الانســان والمفوضـية العليـا للانتخابـات وهيــأة النزاهــة هيئسات مسـتقلة تخضـعـع لرقابـة مجلـس النـواب وتـنظم اعمالهـا بقــانون ) وصـــر بــلك قـانون هيئسة النزاهــة

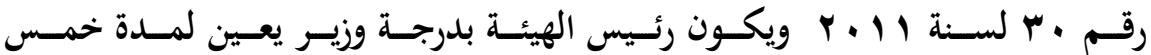

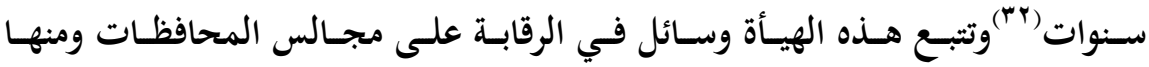

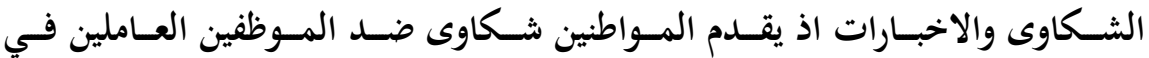

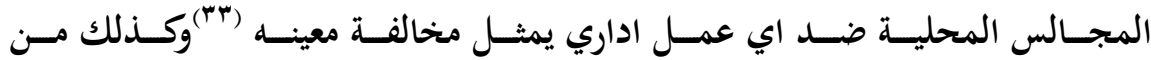

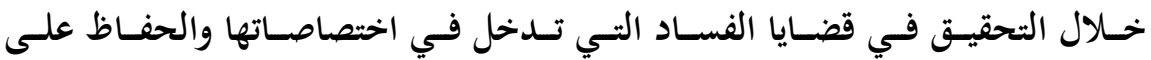

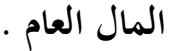
المطلب الثاني: نمط علاقة تعاوني 
تنوعـت اشـكال وصسور التعـاون بـين الحكومسة الاتحاديسة والسـلطات المحليـة

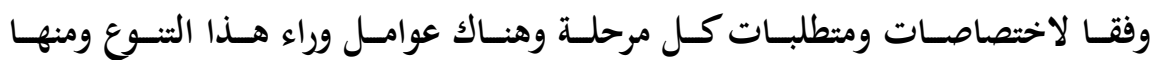
دوافـع التعـاون والظـروف التسي دعـت السى ذلـك ودرجــــ وتقبـل واسـتعداد وحسدات

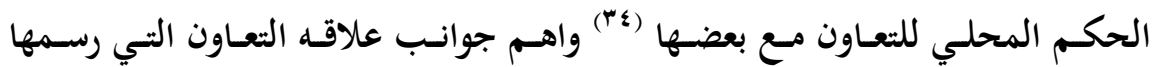

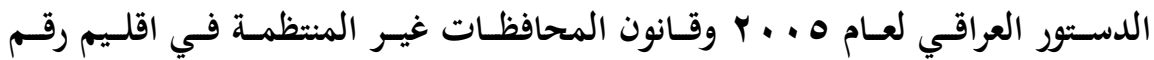

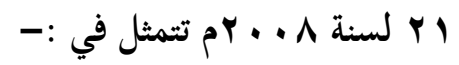

$$
\text { اولا- التعاون في المجال التشريعي }
$$

بما ان السلطة التشريعية وفق الدستور النافذ تتكون من مجلسي النواب والاتحاد وهذا الاخير لم يجرى تشكيله الى الان فأننا سنقتصر على بحثث العلاقه بين مجلس النواب ومجالس المحافظات وضمن هذا الاطار فأن العلاقه تتمثل في توحيد التشريعات وعدم تعارضها مع النصوص الدستورية والقانونية من اجل الحفاظ على الوحده السياسية

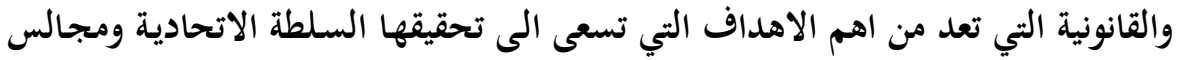

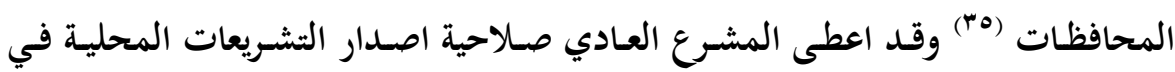

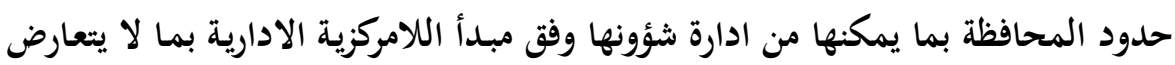

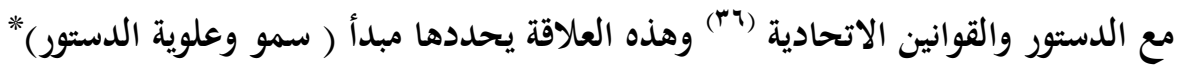
وهو مبدأ دستوريا تقره جميع الدساتير والجهات القضائية في العالم وهذا المبدأ يجعل لهدل الدستور اعلى واسمى القوانين في البلاد ويترتب على الاخذ به عدة نتائج هامه تتمثل في عدم جواز تشريع اي قانون يتعارض مع هذا الدستور سواء كان تشريعا مركزيا اتحاديا او

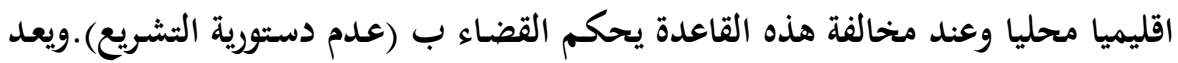
باطلاككل دستور اقليمي او اي نص قانوني تشريعي اذ تعارض مع احكام هذا الدستور

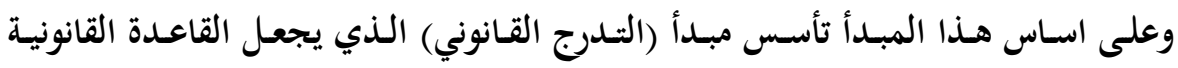
الادنى خاضعة للقاعدة القانونية الاعلى والاولوية تكون للقانون الاعلى في حالة التناقض لهض 
والاختلاف مع القانون الادنى وبموجب هذا التدرج يتم حماية النظام القانوني العام في الدولة واستقراره وبذلك فأن احترام المبادئ الدستورية المتفق عليها فقها وقضاءً ينبغي ان اندي لا يتعارض مع التشريعات الصادره عن السلطة التشريعية الاتحادية او المحلية مع الدستور

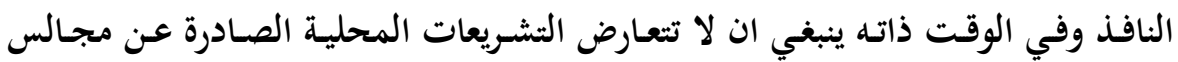

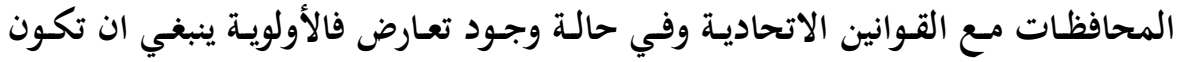
للقانون الاتحـادي الا ان المشـرع العراقي شـذ عن ذلك عند التهدما جعـل الاولويـة للأقـاليم

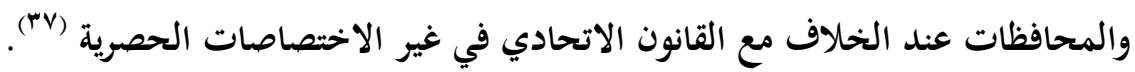

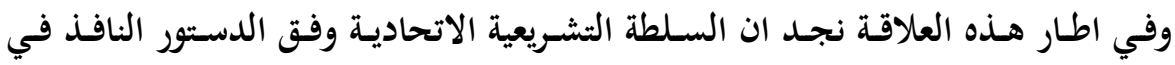

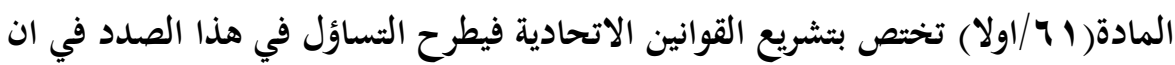

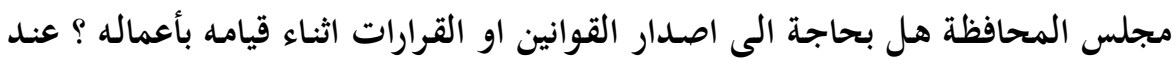
الرجوع الى اختصاصات مجلس المحافظة التي نص عليها قانون المحافظات النافذ في

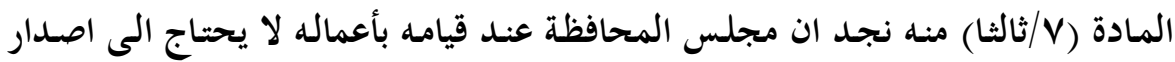
قوانين فالاختصاصات التي يمارسها من انتخاب رئيس المجلس واقالته ونائبه واعداد مشروع الموازنة الخاصة ...الخ كلها ذات طبيعة ادارية لا تحتاج الى اصدار قوانين لان القوانين هي قواعد تصدر لتنظيم امور اقتصادية او ادارية او مالية او سياسية لم تنظم من

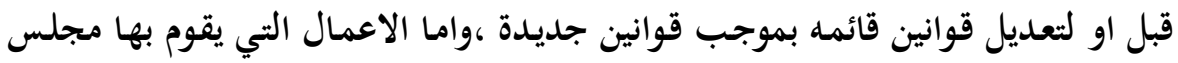

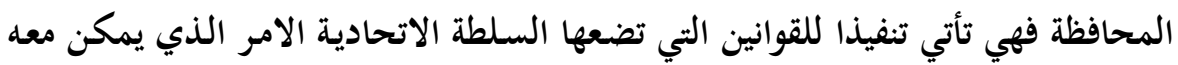
القول بصلاحية مجلس المحافظة في اصدار قرارات لتضعها موضع التنفيذ وتسبغ عليها

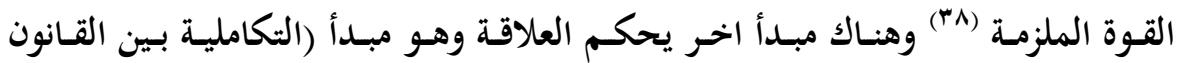

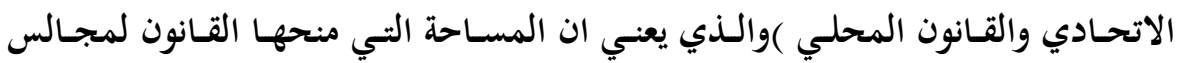
المحافظات لممارسة الدور التشريعي مساحة محدوده ضمن نطاق الوحده الادارية فأي

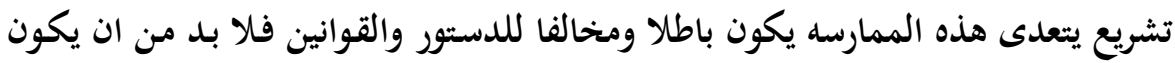

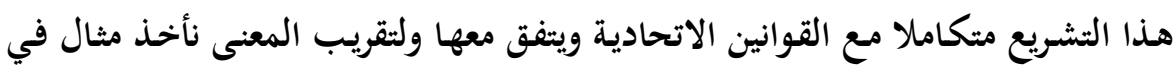
ذلك صدور قانون (تشريع )من مجلس محافظة بغداد يفرض غرامه ماليه على فتح مقاهي 
الانترنت دون اجازة مسبقه من جهة معينة فإذا امتنع المخـالف لهذا القانون عن دفع

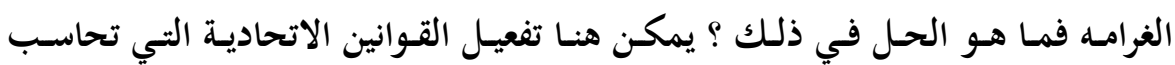

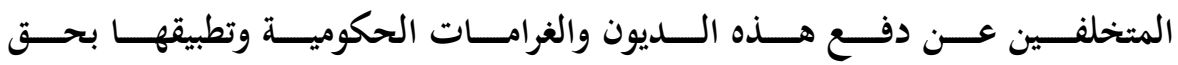
المخالف (9")فالتكامليه هنا ان التشريعات المحلية تتكامل مع التشريعات الاتحادية لكي يمكن تنفيذها وتطبيقها . وهـذا يعني ان الاسـتقلالية التي منحـت لمجــالس المحافظـات لتفعيـل دورهـا وممارسـة صلاحياتها والاستجابة لحاجات السكان المحليين وتلبية متطلباتهم امر هام ولذا في حال

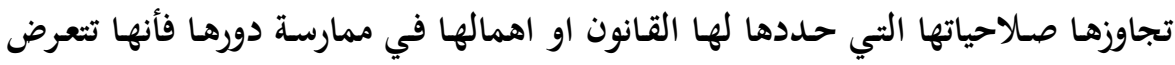

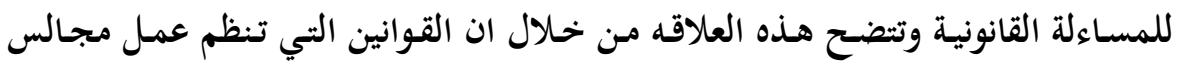

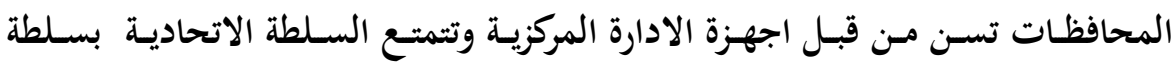
الحلول فهي تستطيع حل مجلس المحافظة في حالة عدم قيامه بدوره المحدد قانونا او في حالة تجاوزه الصلاحيات المحدده له بموجب الدستور الاتحادي والقوانين النافذة

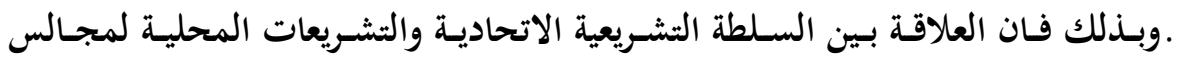

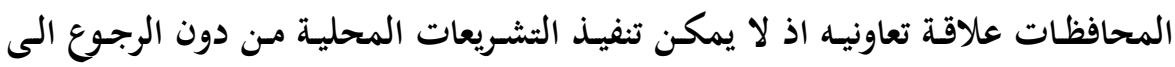

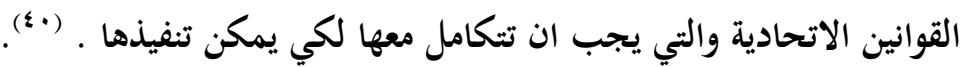
ثانيا- التعاون في المجال التنفيذي ان السلطة التنفيذية الاتحاديـة وفق الدستور النافذ تتكون مـ رئيس الجمهوريـة ومجلس الوزراء وبما ان اللامركزية الادارية تقوم على اساس تقاسم الوظيفة الادارية بين

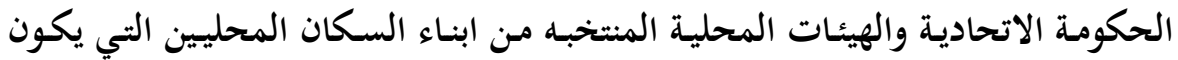

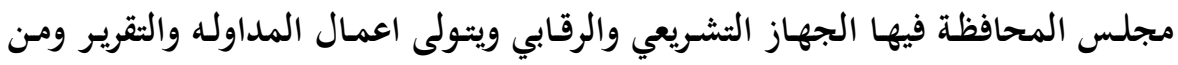
الجهاز التنفيذي الذي يقوم باعمال التنفيذ للقرارات التي يصدرها المجلس المحلي وابرز

$$
\text { جوانب العلاقه في هذا المجال هي :- }
$$

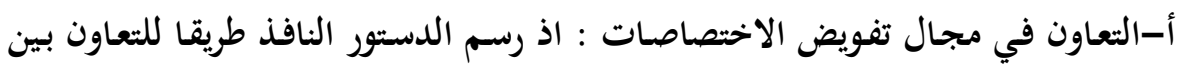

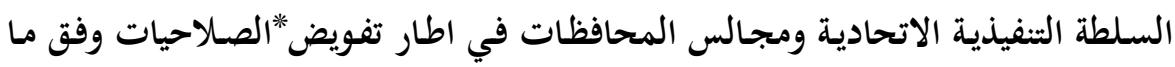




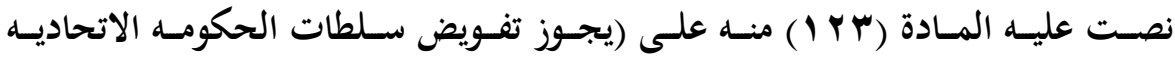

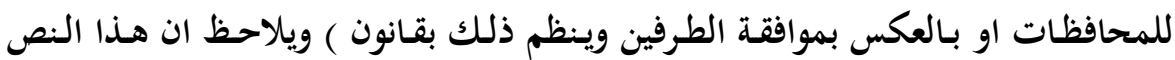
جعل الحكومة الاتحادية في مستوى الهيئات المحليه في المحافظة وهذا امر غريب لانب لان

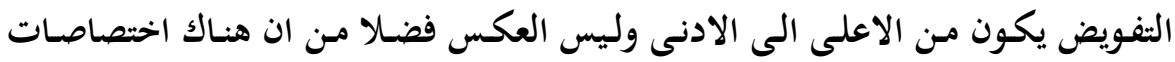

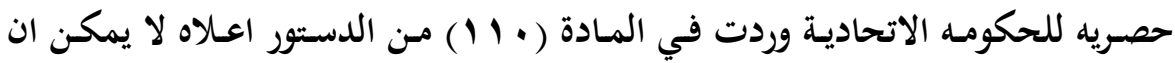

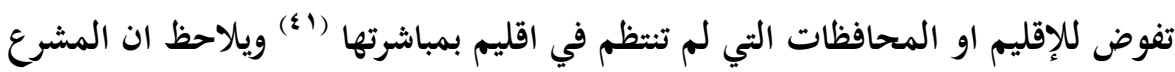

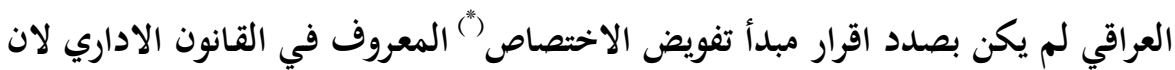

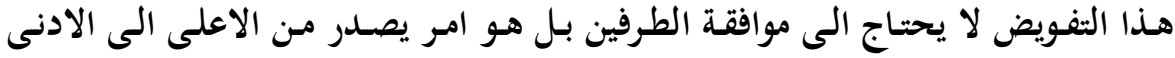

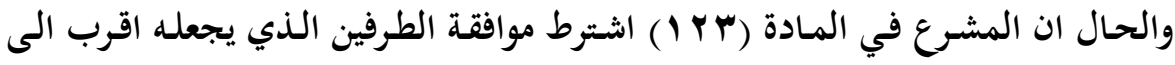

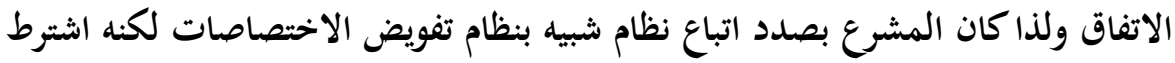

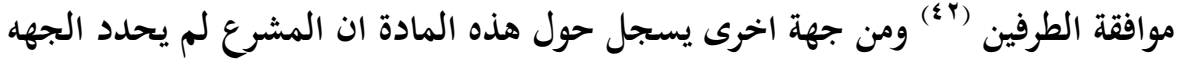
المفوض اليها هل هي مجلس المحافظة ام المحافظ ؟ كما ان التفويض في مجال القانون العام جائز بنـاء على نص صريح ويكون من الاعلى الى الاسفل ولا يمكن ان يحصل

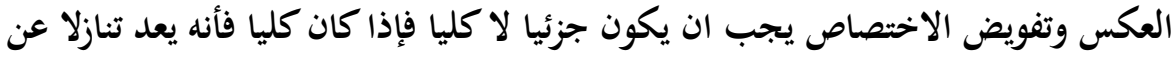

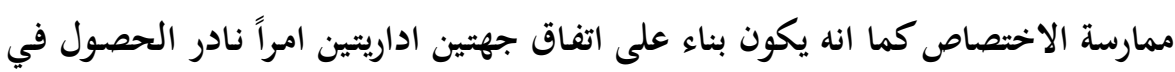

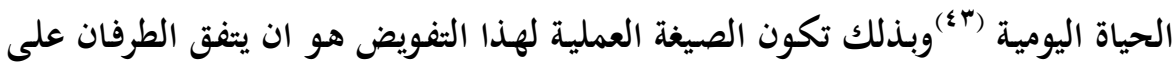

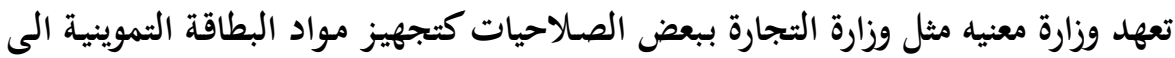
المحافظات وبالعكس يمكن ان تفوض المحافظات بعض صلاحياتها الى فروع الوزارات عندما تدرك اهمية ذلك وقد حصل ذلك في الواقع عندما قررت وزارة التربية بسبب تلكؤ

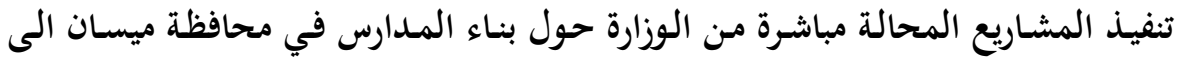

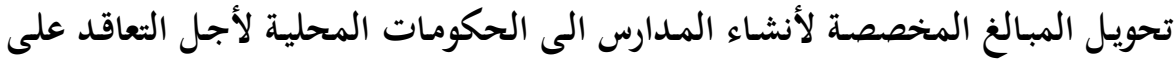

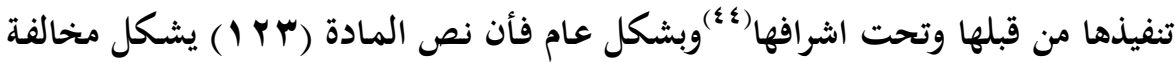
صريحة لما هو متعارف في الدول التي تتبنى النظام الفيدرالي حيث النفويض في المجال 
التشريعي والاداري للمستويات المختلفة من الحكومة الفيدرالية الى المستويات الادنى

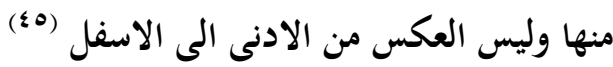
ب-تأسيس مكاتب في السفارات والبعثات الدبلوماسية : يظهر وجه تعاون اخر ضمن الاسلى

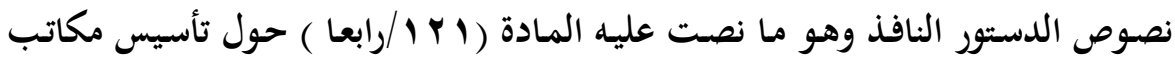
للأقـاليم والمحافظـات في السـفارات والبعثـات الدبلوماسـيه لمتابعسة الثـؤون الثقافيسة

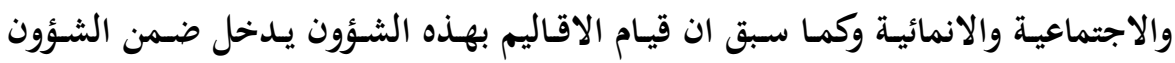

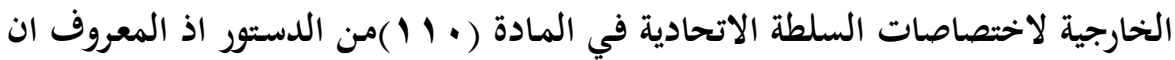
اغلب دول العالم تركز فيها الحكومة الاتحادية على الشؤون الخارجية والدفاع والامن الداخلي والتعليم والبنى التحتية الاقتصادية والصحة وقد احدثت المادة ( ا ب / /رابعا )

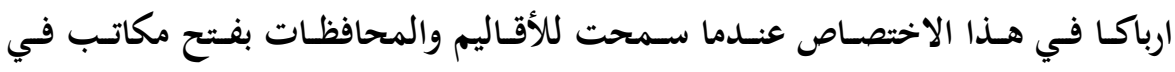

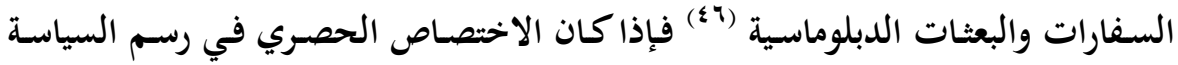
الخارجية ممنوح للحكومة الاتحادية فلماذا نفرض عليها تأسيس مكاتب ممثله للأقاليم والمحافظات في الممثليات الدبلوماسية ؟ وهو امر يتعارض مع وحدة التمثيل الدبلوماسي

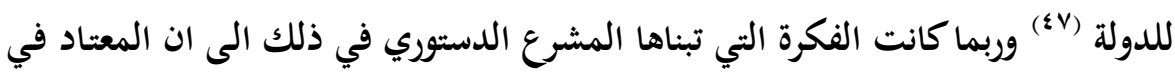

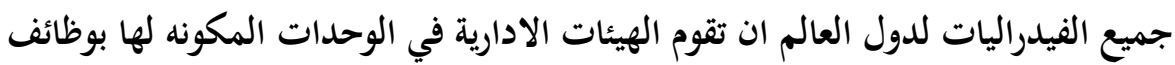
الفيدرالية سواء كان ذلك رسميا او تبعا لإجراءات غير رسميه ومن ضمنها لهيها ادارة المنح

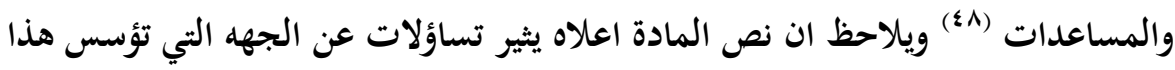

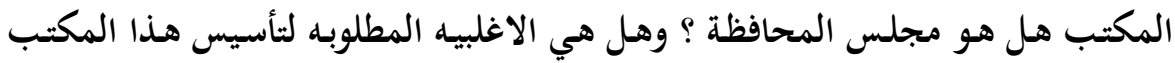
وعلى من تقع نفقات هذه المكاتب هل على الحكومة الاتحادية ام على المحافظة وهل يحتاج تأسيس هكذا مكاتب الى موافقة الحكومة الاتحادية ام فقط التنسيق معها ؟ ولم

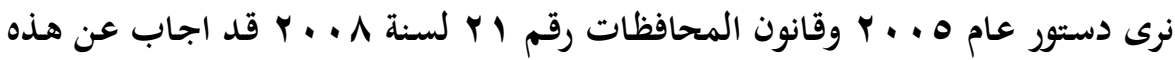

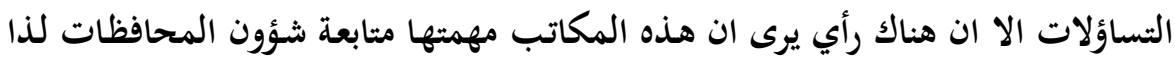

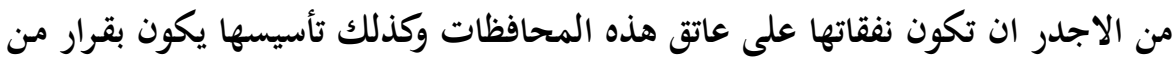
مجلس المحافظة بعد ترشيح اعضاءه من قبل المحافظ بنفس الاليه التي رسمت اختيار 
اصحاب المناصب العليا واما بخصوص الحصول على موافقة الحكومة الاتحادية فأن

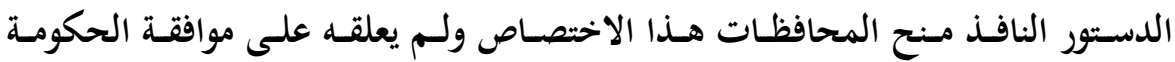
الاتحادية وبالتالي فأن المطلق يجري على اطلاقه ولابد من وجود تنسيق بين المحافظات

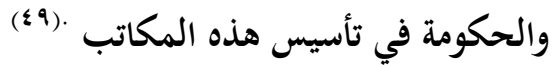
ج- رسم السياسة العامة للمحافظة بالتنسيق مع الوزارات المعنيه في مجال تطوير الخطط المتعلقه بالمحافظة(·) وقد خص المشرع العادي مجلس المحافظة بصلاحيات تدخل

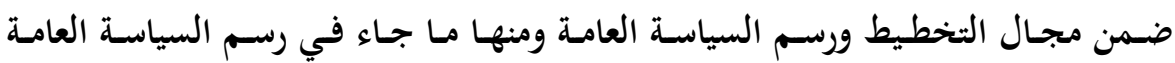
للمحافظة وكذلك ما جاء في المادة (V/خامس عشر ) في تحديد اولويات المحافظة في

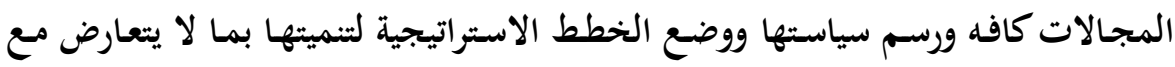

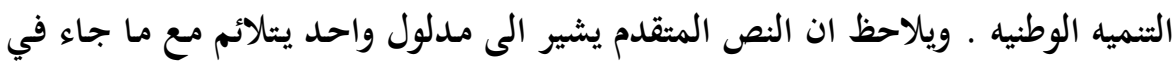

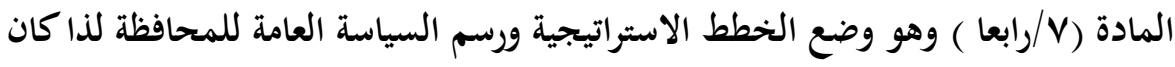

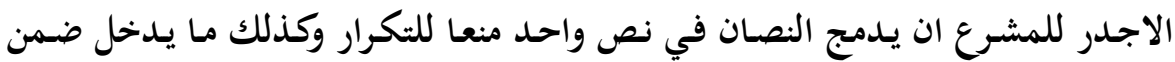
هذا الاختصاص هو التصديق على الخطط الامنية المحلية المقدمة من قبل المؤسسات الامنية في المحافظة عن طريق المحافظ بالتنسيق مع الدوائر الامنية الاتحادية مع مراعاة خططها الامنية (1) د-الهيئة العليا للتنسيق(*) بين المحافظات : ويمكن ان نجد جانب اخر من العلاقة بين

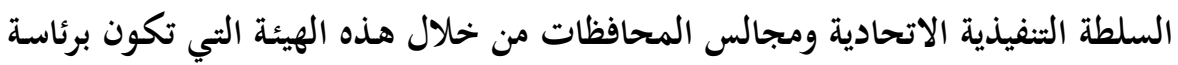
رئيس مجلس الوزراء وعضوية وزراء (البلديات والاشغال العامة ،الاعمار والاسكان ،العمل

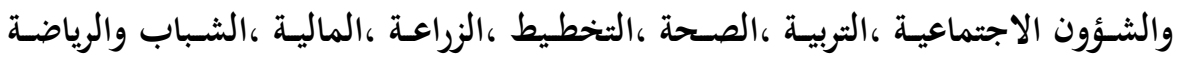

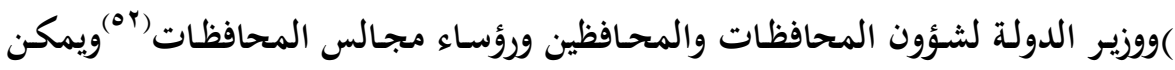

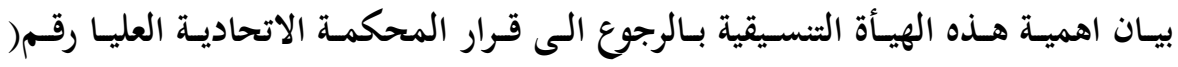

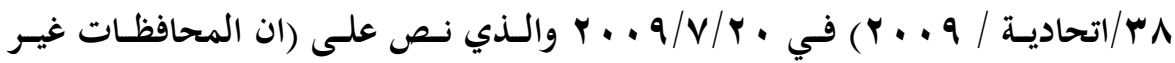
المرتبطة بإقليم اصبحت غير مرتبطة بوزارة وتخضع لرقابة مجلس النواب وتتبع القرارات

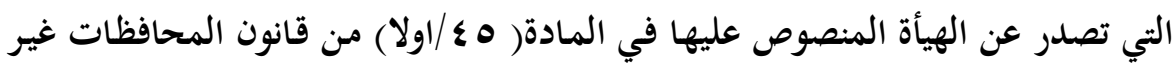




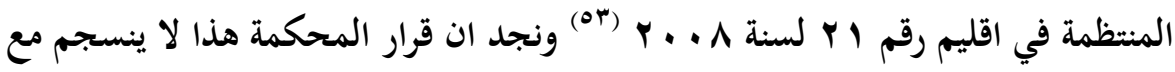

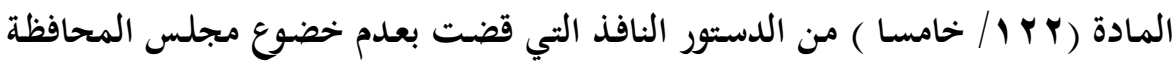
لسيطرة او اشـراف اي وزارة ، وكسون هذه الهيأة التنسيقية برئاسـة رئيس مجلس الوزئس الوزراء وعليه فأن القرارات التي تصدرها الهيأة لا تلزم مجالس المحافظات بخضوعها التهات استنادا الى لى المادة اعلاه ـ وتأتي مهمة هذه الهيأة في النظر الى شؤون المحافظات وادارتها المحلية

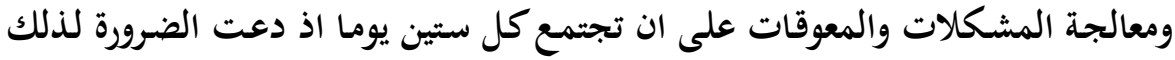
كما انها تأتي منسجمة مع المادة (VN) من الدستور النافذ والتي تعتبر رئيس مجلس

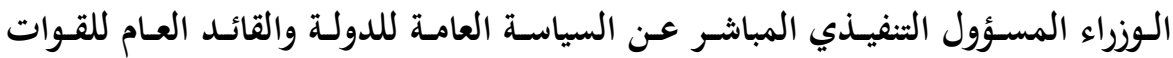
المسلحة يقوم بإدارة مجلس الوزراء ويترأس اجتماعاته وله الحق في اقالة الوزراء بموافقة المبن

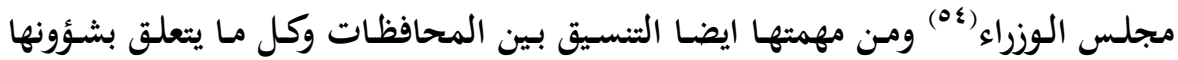

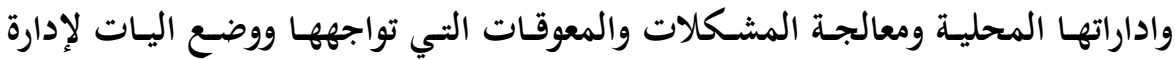
الاختصاصات المشتركة بين الحكومة الاتحادية والحكومات المحلية المنصوص عليها في المواد (Y | | | | | |-ع | | ) من الدستور والنظر في تفويض السلطات الاتحادية التي

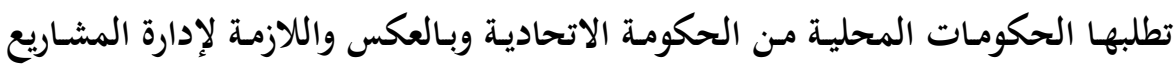

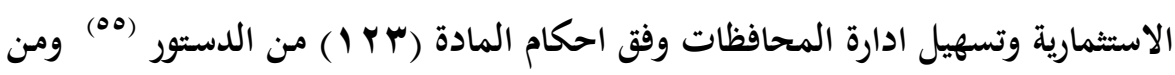
الجدير بالذكر ان المشاريع الاستثمارية المخصصة للمحافظة والتي تنفذ من قبل دوائر

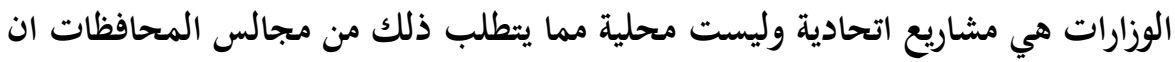
تضع خططها ومشاريعها المحلية على نحو لا يتعارض مع الخطط والمشاريع الاتحادية

المطلب الثالث: نمط علاقة تداخلي ان تداخل الاختصاصات اصبح يشكل ازمة دستورية وقانونية مما يربك بالنتيجة

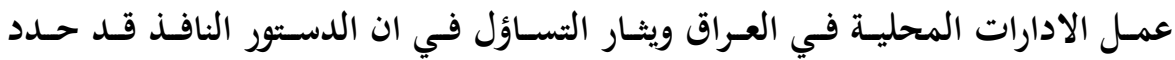
الاختصاصـات الحصرية للسلطة الاتحادية في المـادة ( • 11) منسه وبين الاختصاصـات

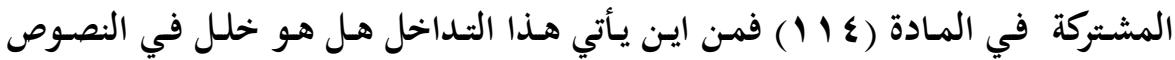


الدستورية والقانونيـة ام وجـود مـؤثرات ومصـالح تـدفع الى الابتعـاد عـن الالتزام بهـذه

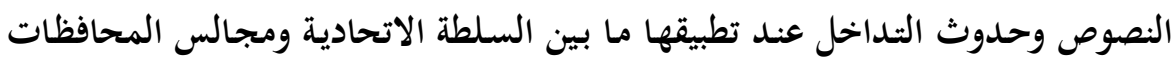

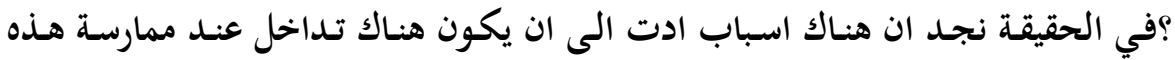
الاختصاصات وسنتاول ما يلي :اولا - اسباب حدوث تداخل الاختصاصات وتتمثل في :1-ضعف المنظومة التشريعية : اذ يشكل ضعف المؤسسة التشريعية سبب رئيسي في حدوث التداخل فهناك العديد من القوانين التي لم يتم سنها الى الان والتي تعزز (مجالس

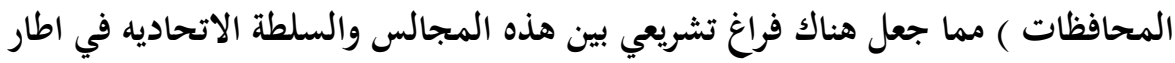
تعزيز اللامركزية الادارية ومن ابرز هذه القوانين ما نص عليه الدستور النافذ في تشكيل هيئة عامـة لضسمان حقوق الاقاليم والمحافظات غير المنتظمـة في اقليم في المشاركة

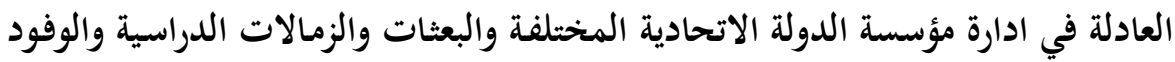

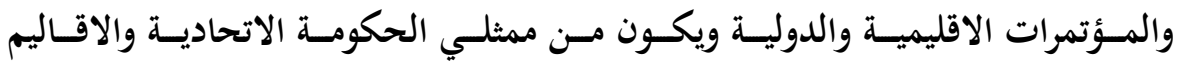

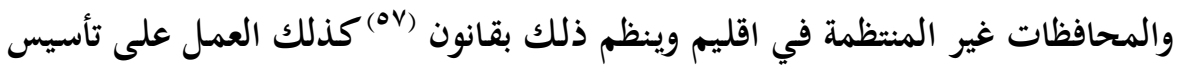
هيئه عامه لمراقبة تخصيص الواردات الاتحاديه والتي تتكون من خبراء الحكومه الاتحادية والاقـاليم والمحافظات وممثلـين عنها لتحقيق العدالـة في توزيـع المسنح والمسـاعدات

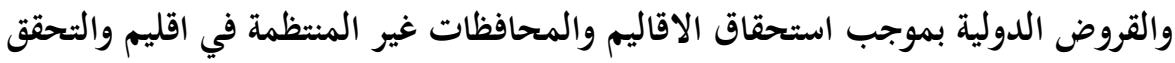

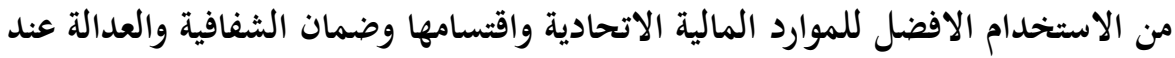

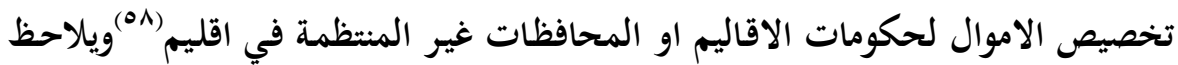

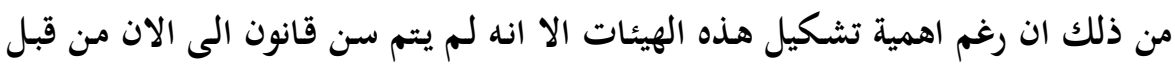
مجلس النواب مما يسجل اشارة واضحة على ضعف المنظومة التشريعية وعدم التكاملية في اصدار القوانين فالدستور ينص على تنظيم وضع ما في قانون تسنه السلطة التشريعية الاتحادية لاحقا الا ان النص الدستوري يبقى معطلا لعدم وجود قانون ينظمه .

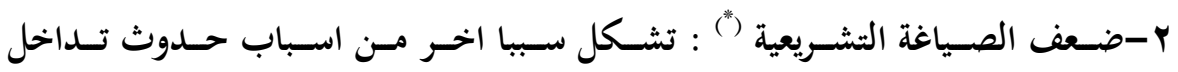
الاختصاصات فأن المنظومه التشريعية واجهت عدة تناقضات ومن اهمها هو وجود قوانين 
سنت قبل عام ץ + . † تتميز بقوة ونفاذ الحكومة المركزية ما يحد وبدرجة كبيره من السير نحو ترسيخ نظام اللامركزية الادارية فضلا عن وجود تعارض وتناقض في كثير من القوانين

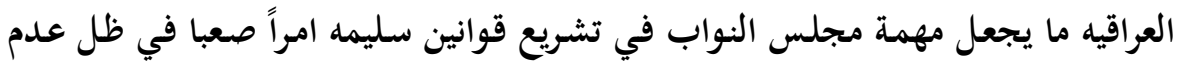

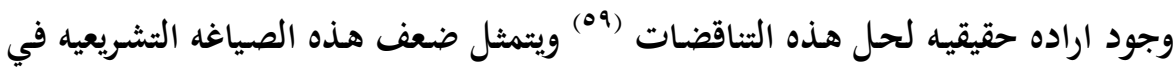

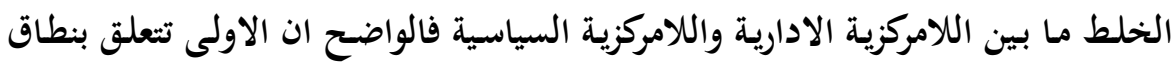

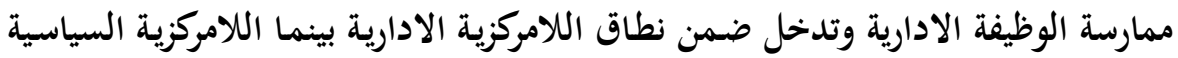
تقوم على اسـاس تقاسـم الوظـائف الثلاث التشريعية والتنفيذيسة والقضـائية بـين السـلطة الاتحادية والاقاليم ، والتداخل في الصلاحيات لم يشفع له وجود احترام حقيقي للمرجعيه

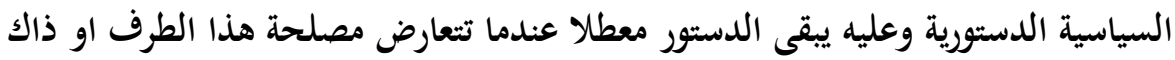

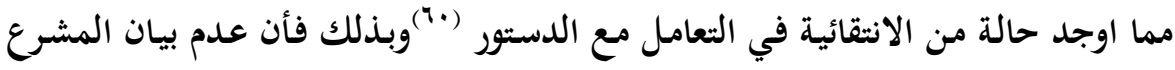

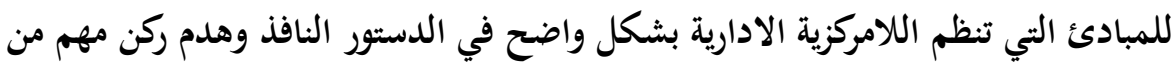
اركانها وهـو الرقابـة يمثل عيـب اخر مـن عيـوب الصسياغة التشـيعية فضسلا عـن غموض

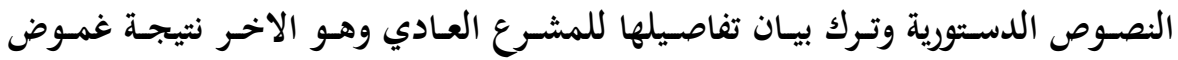
النصوص الواردة في الدستور اتجهه الى اتجـاه اخـر في اخضـاع هـذه المجـالس لرقابـة مجلس النواب.ونصه في قانون المحافظات النافذ على تمتع مجالس المحافظات بسلطة اصدار التشريعات المحلية مما يدل على الخلط الواضح وعدم فهم المبادئ الاساسية

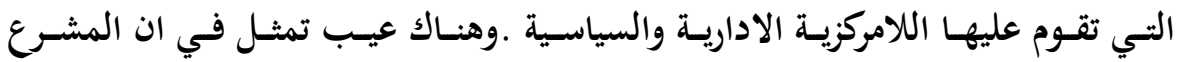
الدستوري جعل عنوان الباب الخامس من الدستور (سلطات الاقاليم) الا ان هذا العنوان لا ينسـم مـع محتوى ومضسمون هـذا الباب لان مواده عالجـت كل مـا مـا يتعلق بالأقاليم والمحافظات غير المنتظمة في اقليم لذلك ينبغي ان يكون محتواه موافق لما جـاء بـه

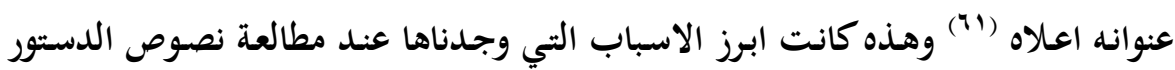

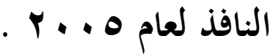
ثانيا: مظاهر تداخل الاختصاصات

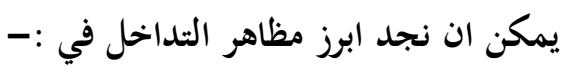


1- الاختصاصات المشتركة بين الحكومة المركزية والاقاليم والمحافظات : والتي يقصد بها الاختصاصات التي تكون محل تداخل بين الحكومة الاتحادية وحكومات الوحدات

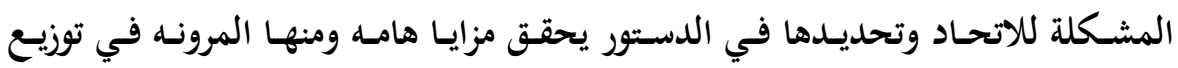

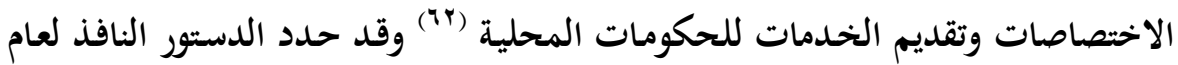
ه . . ب الاختصاصات المشـتركة بين السلطات الاتحادية والاقاليم بأنها : ( اولا-ادارة الجمارك بالتنسيق مـع حكومات الاقاليم والمحافظات غير المنتظمه في اقليم وتنظم بقانون ،ثانيا-تنظيم مصادر الطاقه الكهربائيه الرئيسيه وتوزيعها ،ثالثا-رسم السياسة البيئيه لضمان حماية البيئه من التلوث والمحافظة على نظافنها بالتعاون مع الاقاليم والمحافظات غير المنتظمه في اقليم ،رابعا-رسم سياسـات التنميـة والتخطيط العـام ،خامسـا-رسمـ السياسـة الصـحية العامـة بالتعـاون مـع الاقـاليم والمحافظـات غيــر المنتظمسة في اقلـيم

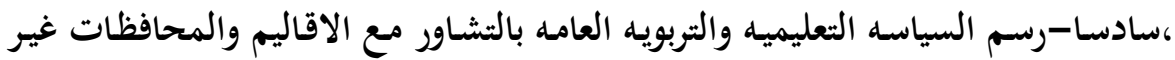
المنتظمة في اقليم ،سابعا-رسم سياسة الموارد المائية الداخلية وتنظيمها بما يضمن توزيعا

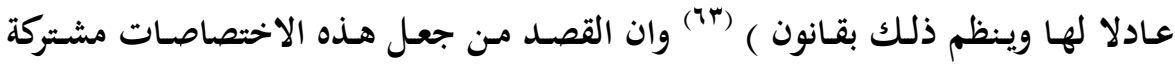

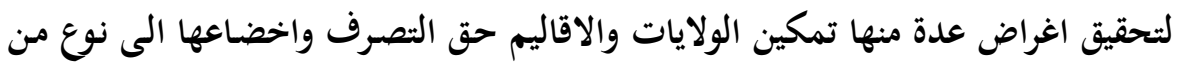

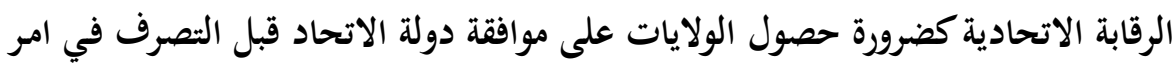

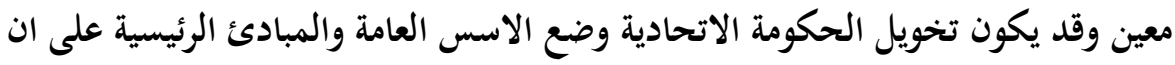

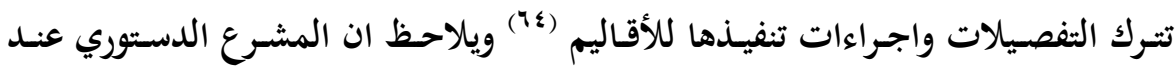
توزيعه للاختصاصـات فأنه جعل اختصاصـات الاقاليم عامة وجعـل اختصاصـات السـلطة الاتحاديـة حصرية وهـذا مخحالف لمـا هـو متبع في توزيـع الاختصاصـات بـين السـلطات

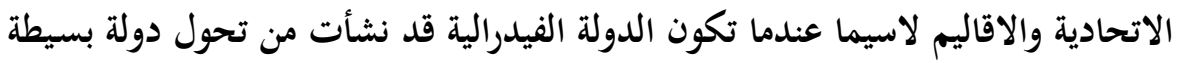
الى دولة مركبة وهـذا الاتجـاه ربمـا جـاء نتيجة الافراط في تركيز المركزيـة في ظل نظام

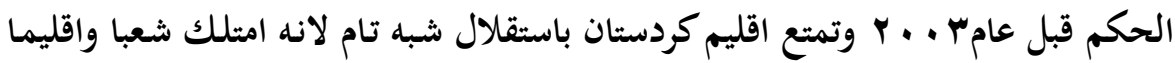

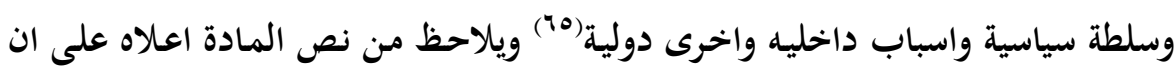

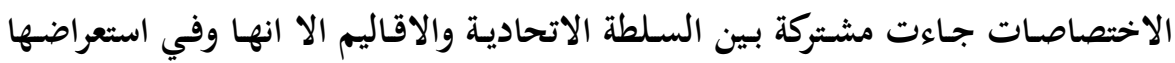


لبعض هـذه الاختصاصـات اشركت المحافظات غير المنتظمة في اقليم بها فجاء شيئا

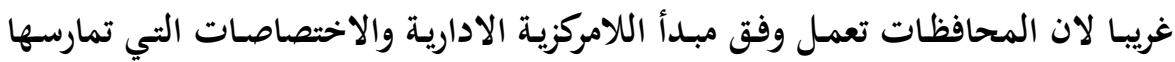
اختصاصات دستورية تكفل القانون بها لا الدستور وعليه فأن زج المحافظات في ممارسة نفس اختصاصـات الاقليم يعـد خلطا بين نظامي الفيدرالية واللامركزيـة الاداريـة وطمس معالمها بمعنى ان المشـرع الدستوري سـاوى في ذلك بين الاقاليم والمحافظات غير المتنظمة في اقليم في ممارسة الاختصاصات التي لم يحصرها الدستور وهذا لا يجوز لان

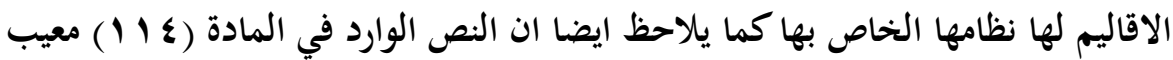

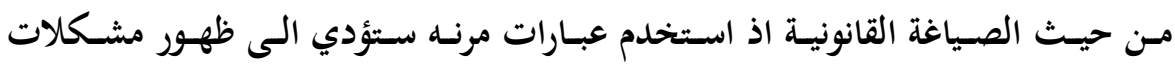

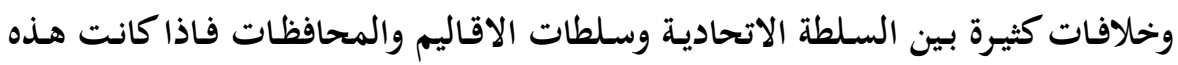
الاختصاصات مشتركة فلماذا الاحاله في صدر كل بند الى السلطة الاتحادية كالقول ادارة الجمارك بالتنسيق مع الحكومة الاتحادية .. الخ وهذا يعني ان السلطة الاتحادية هي التي ترسم فكان الافضل الاشتراك من خلال التنفيذ وليس التشريع ولعل السبب في جعل هذه

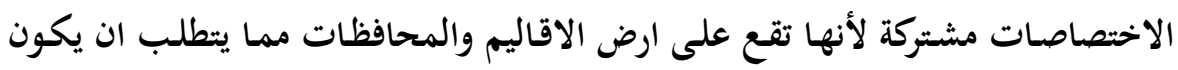

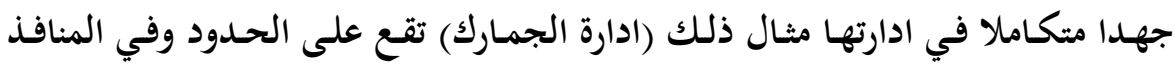

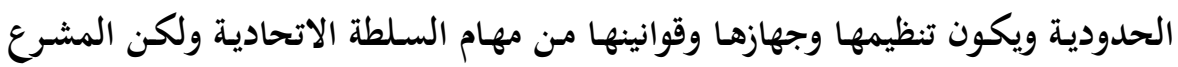

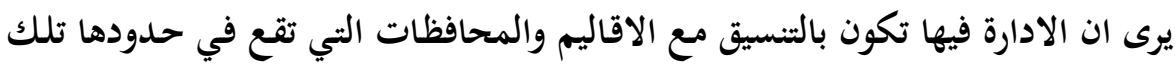

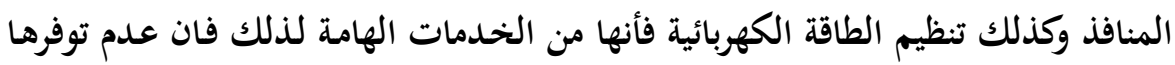
يؤدي بالمواطنين الى النظاهر مطالبين السلطة الاتحادية بالكهربـاء ولان مصادر الطاقة وتوفيرها يحتاج الى خبرات فنيه وقدرات بشريه وامكانيات ماليه فليس بوسع المحافظات القيام بها ولان السلطة الاتحادية هي المسؤولة عن تنظيم محطات التوليد والتوزيع يأتي

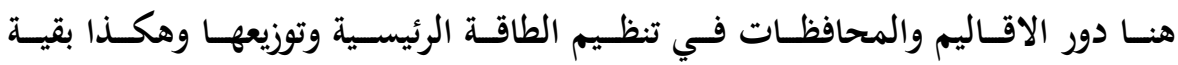

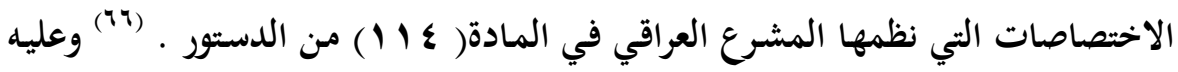

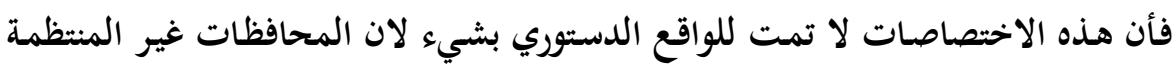

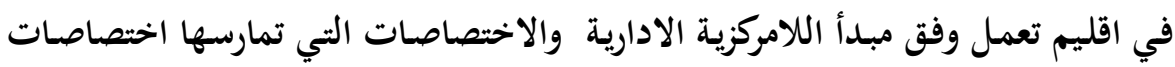


ادارية يتكفل القانون بتحديدها وعليه هذه ابرز مظاهر التداخل في تطبيق الاختصاصات

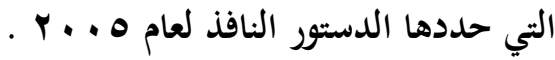
المبحث الثاني: مستقبل العلاقة التفاعلية

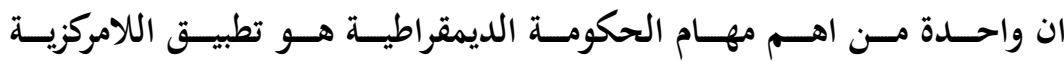

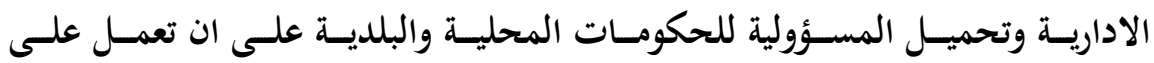

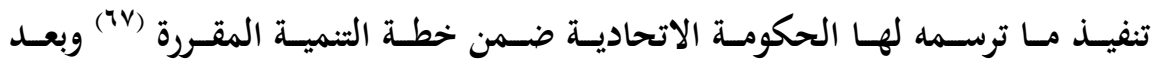

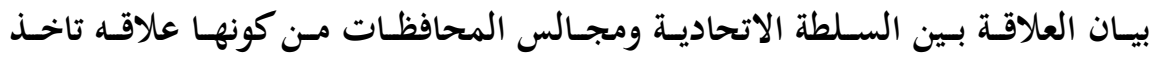

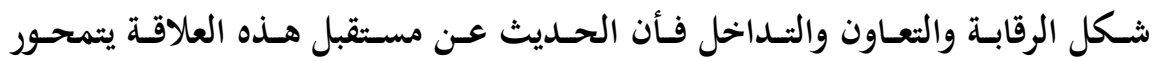
في افتراضات اساسية وهي :المطلب الاول : قوة الاطراف المحلية .

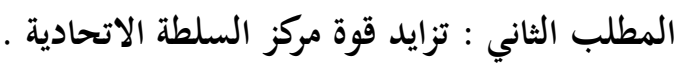
المطلب الاول: تزايد قوة الاطراف المحلية

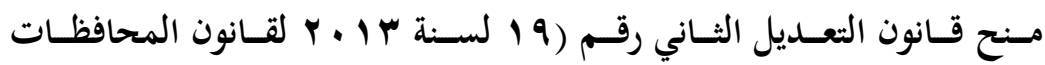

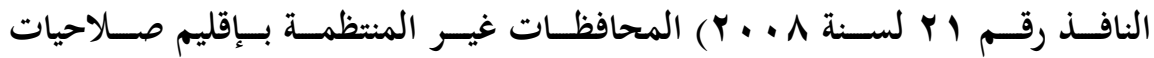

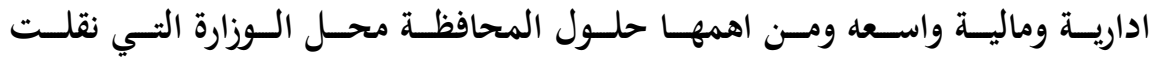

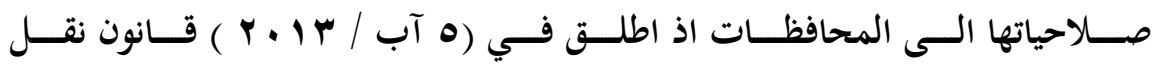
الصـلاحيات والــذي تضــمن نقـل (^) وزارات خدميسة الـى هـــه المحافظــات وفـق

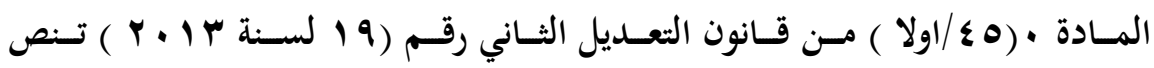
علسى ( نقـل الـدوائر الفرعيسة والاجهـزة والوظــائف والاختصاصسات التسي تمارسـها

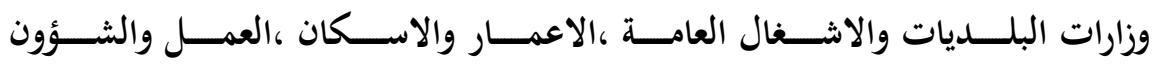

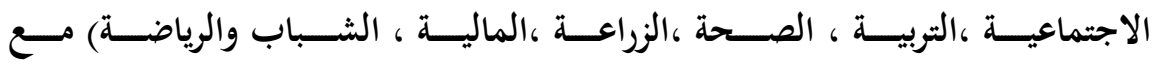

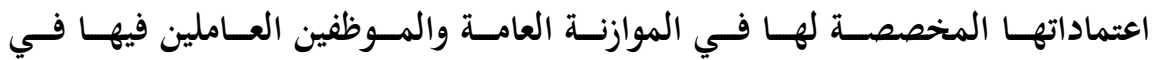
المحافظـات في نطـاق وظائفهـا المبينسة في الدسـتور والقـوانين المختصسة بصـورة

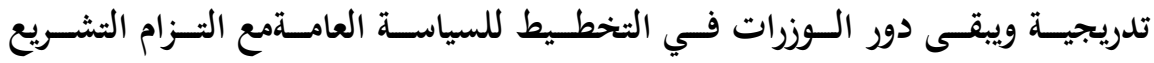


بالتنفيـذ خــلال عـامين مـن انطلاقـة وبعـدها تنقـل الصـلاحيات بحكـم القـانون الا ان

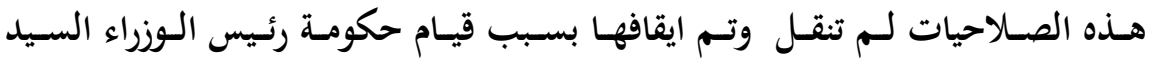

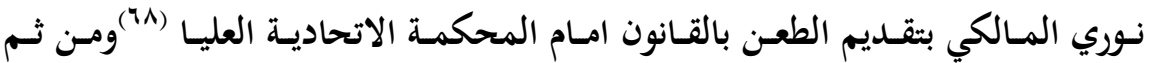

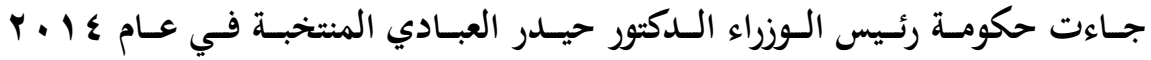
وبـادر الى تفعيـل قـانون نقـل الصـلاحيات وسـحب الطعن مسن المحكمسة الاتحاديسة

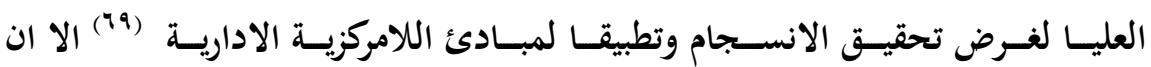

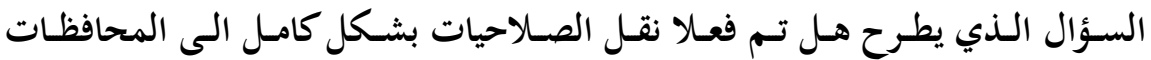

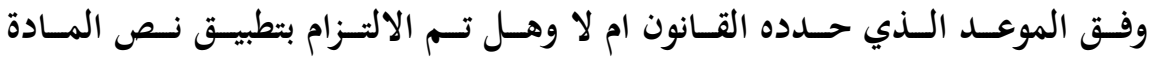

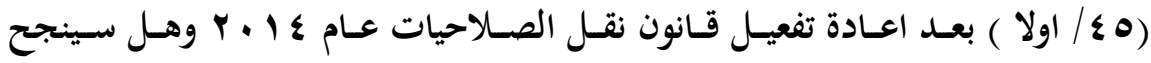
المعنيين في المحافظات بالأعمال والصلاحيات التي ستنقل اليهم ؟ بهات

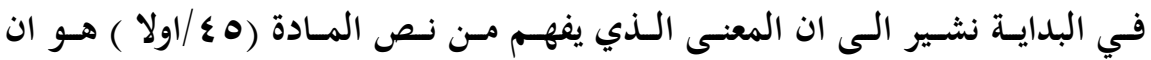

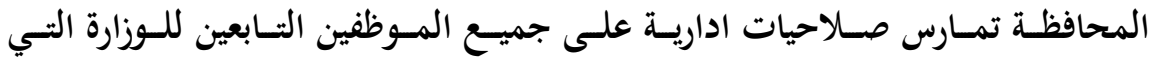
نقلـت صـلاحياتها طبقـا للقـوانين التـي تـنظم عمـل الـوزارة ويكـون للمحــافظ سـلطة الـوزير المخـتص على جميـع العـاملين في المحافظـة فيمـا يتعلـق بشـؤونهم الاداريـة

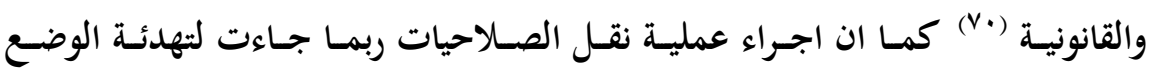

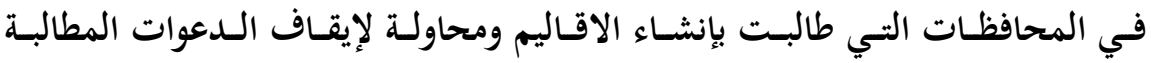

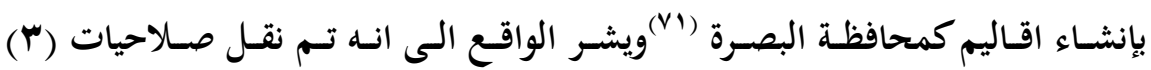

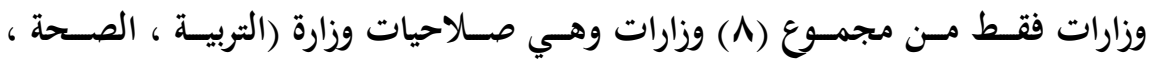

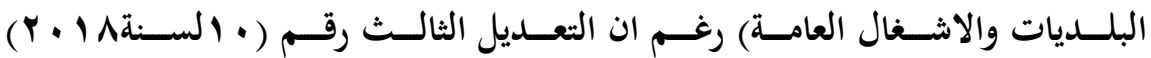

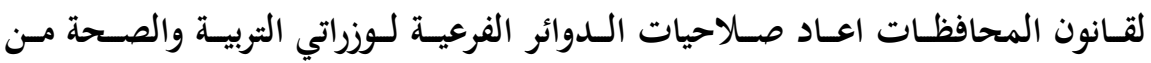

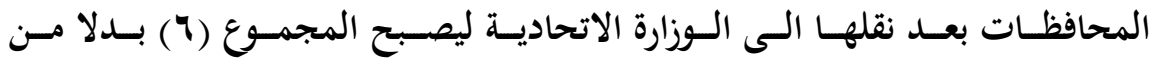

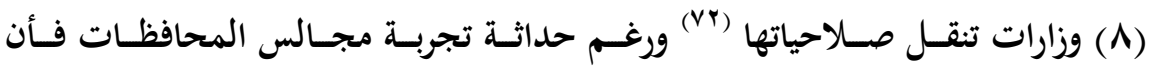

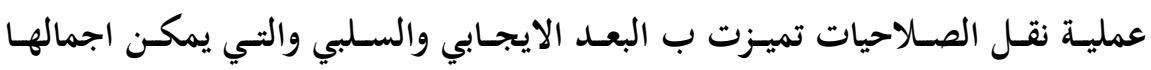

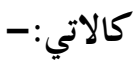




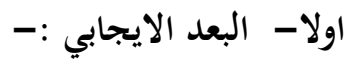

1-تعـــ عمليـة نقــل الصـلاحيات ترسـيخ لمقومـات النظـام الفيــرالي فـي العـراق

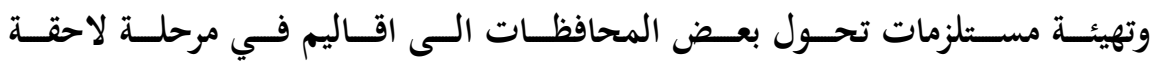

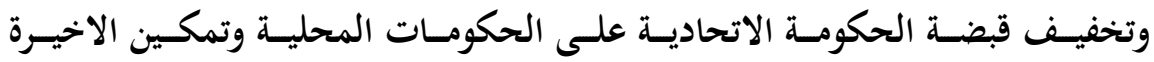

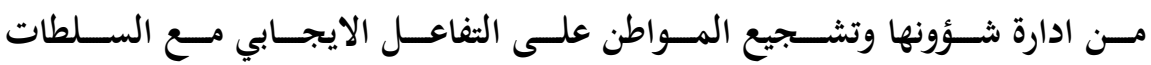

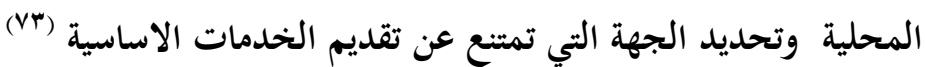

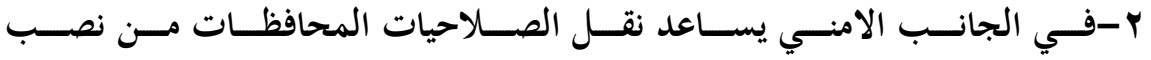

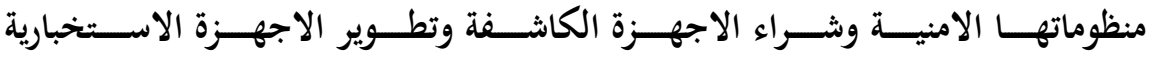

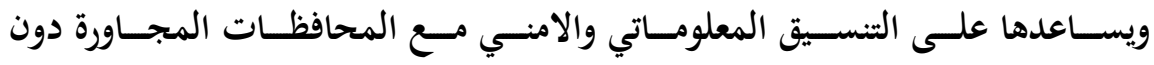
اللجـوء الـى الحكومـة الاتحاديـة التسي تضـع الخطـط الامنيسة للمحافظـات وتعيسين

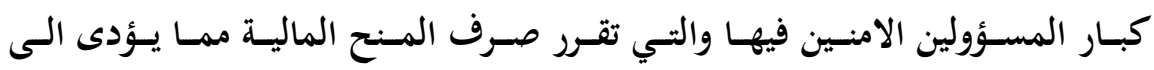
تأخرها وضعف تنفيذها لذلك وعدم التفرغ للمسائل القومية (v)

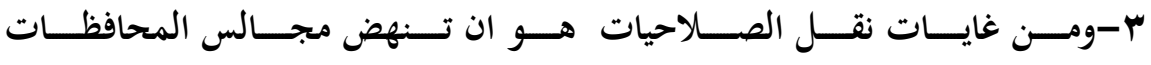

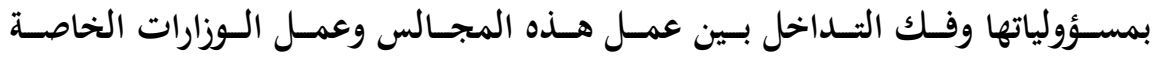

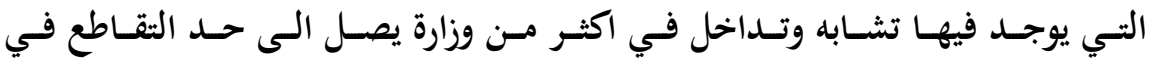

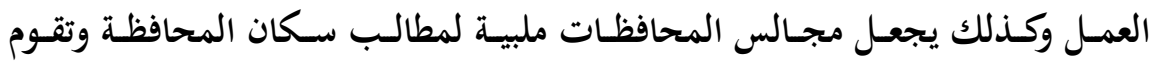

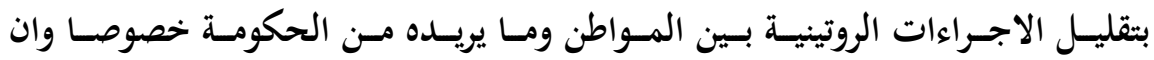

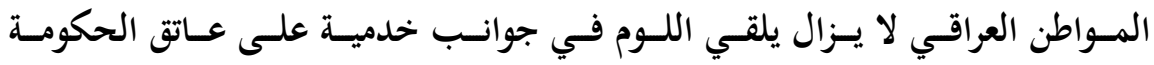

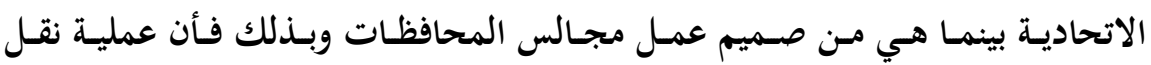

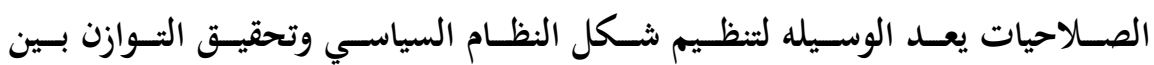
الحكومة الاتحادية ومجالس المحافظات (V0)

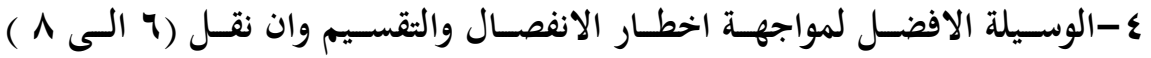

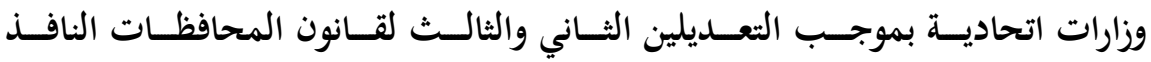

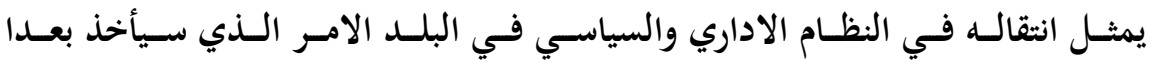


سياسـيا واقتصــاديا ويولـد مســاحة وتنافســا ايجابيـا وفعـالا بـين المحافظــات ممــــا يؤدي الى تطوير وسائل التنمية (V)

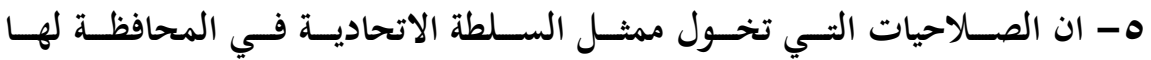
فائدتان وهما :- (VV) أ-تسـهـيل سـير العمـل داخـل المحافظــة فيخــف الضــط المتواصـل علـى الـوزير

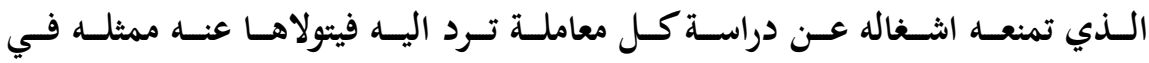

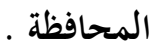

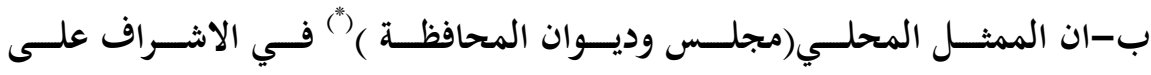

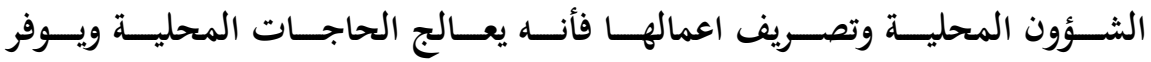

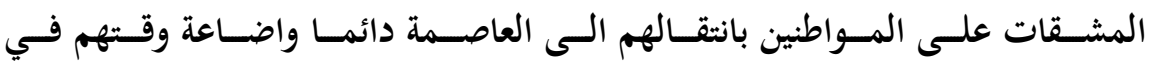

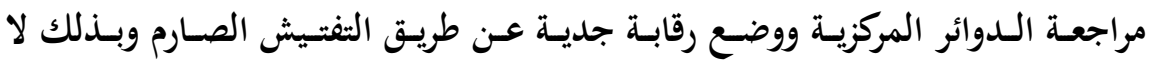
تصدر اي قرارات واي تصرف الا في حدود القانون

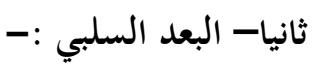

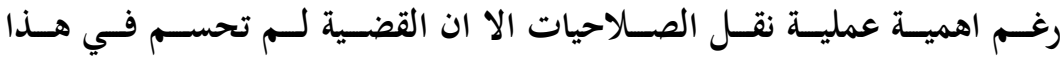

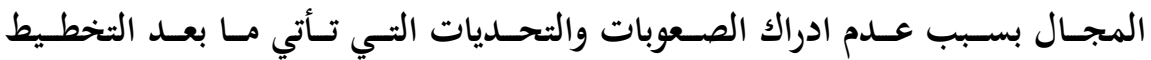

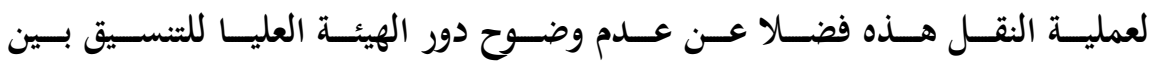

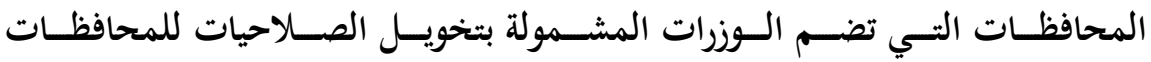

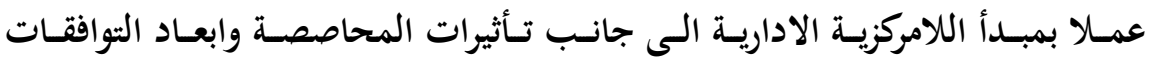

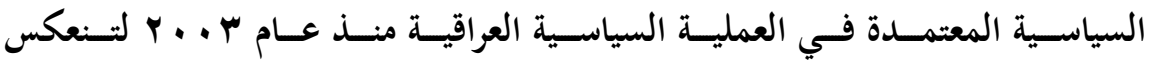

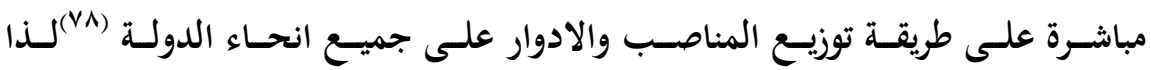

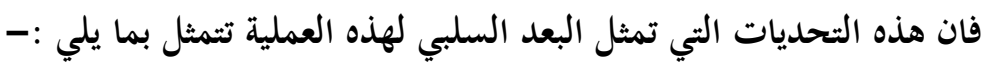

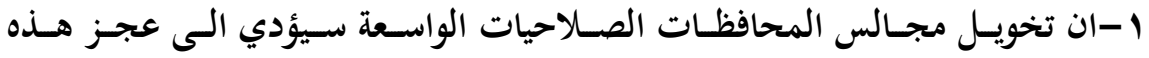

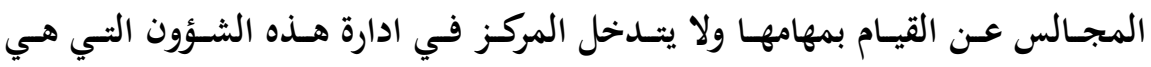
من اختصاصاتها وذلك سيؤدي الى الارباك وتوقف العمل فيها (v9). 
ץ-اعتـراض الـوزراء فـي الـوزارات علـى عمليـة نقـل الصـلاحيات اذ يشـكل مخحالفــة

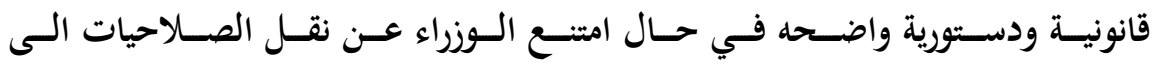

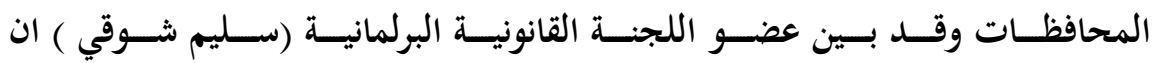

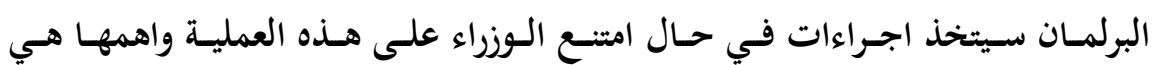
(A.) - :

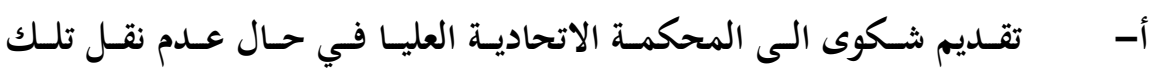
الصلاحيات من قبل الحكومة.

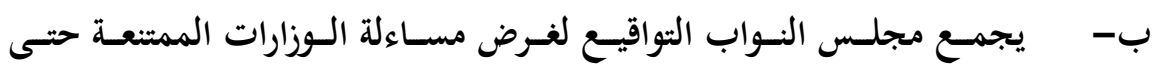
تحجب الثقة عن هؤلاء الوزراء. ت- امكانيسة تطبيـق قـانون نقـل الصـلاحيات مـن قبـل المحافظـات الا انسه قــــ لا يتحقق الهدف المرجو منه الا من خلال التنسيق مع تلك الوزارات .

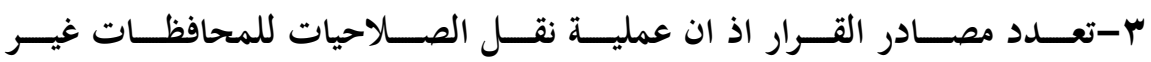

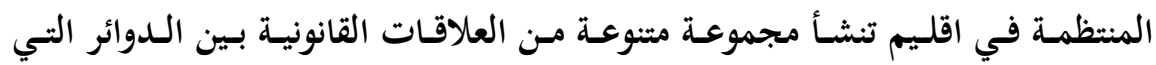

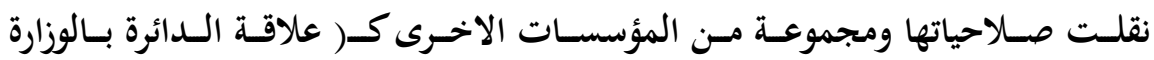
الاتحاديـة ، علاقـة الــائرة بـديوان المحافظـة ،علاقـة الــائرة بمجلـس المحافظـة ،

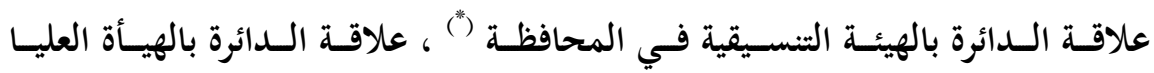

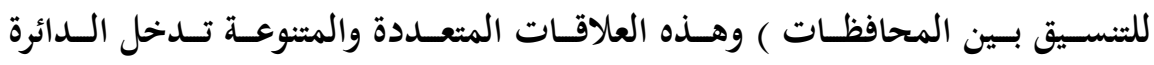
صـاحبة الاختصـاص في دوامـة الاربـاك والضـعف في حسال تضـارب القـرارات ممـا

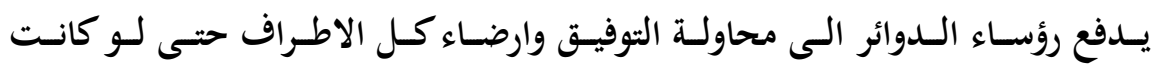

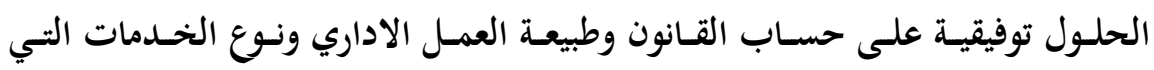
تقــدمها نتيجــة تعـدد مـراجعهم الوظيفيـة والجهـات التي تتـولى اعمـال الرقابـة علـيهم

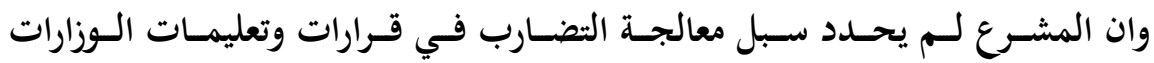

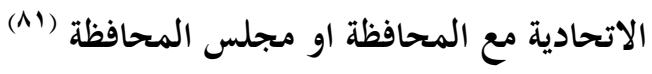


ع -عـدم اســكمال الاسـتعدادات فـي كثيـر مـن المحافظــات لنقـل الصــلاحيات

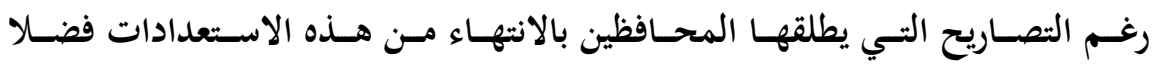
عـن الثــلل وفوضسى المخاطبـات للخـروج مـن التشـابك والتقـاطع بــين الادارات

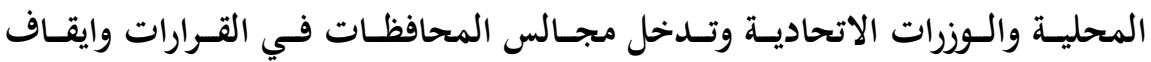

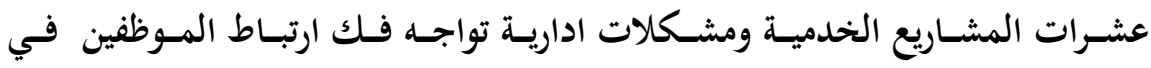

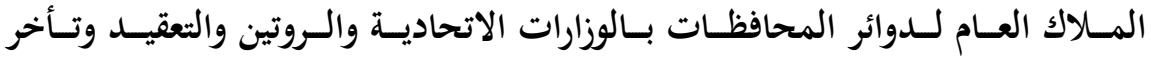
انجاز آلاف المعاملات (Ar) ه-هنـاك مـن يـرى ان نقـل الصـلاحيات للمحافظـات لـن يقـود الـى تحقيـق اسـتقرار سياسـي وانجــاز حقيقـي لهـذه المحافظـات بسـبب الصــراعات الحزبيسة والسياسـية والتي سـتكون علـى نحسو اكثر شـدة مـع اول تجربـة انتخابيسة في تلـك المحافظـات

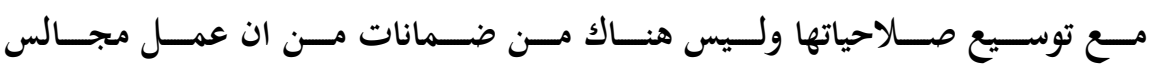
المحافظـات مـع نقـل الصــلاحيات سـيقود الـى تقلـيص نسـب الفســاد الاداري

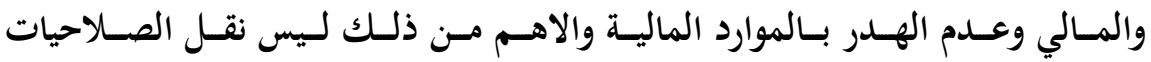

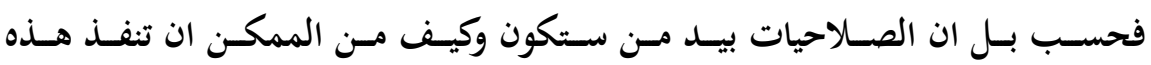

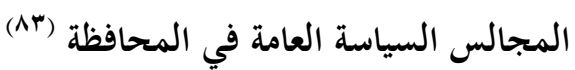

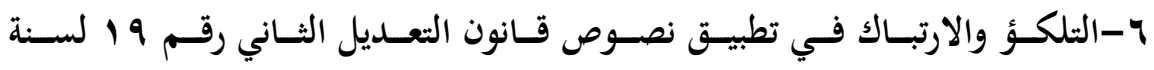

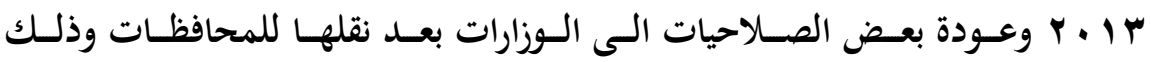

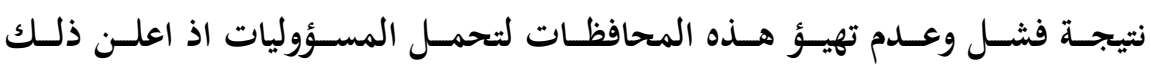
وزيــري التربيـة والصـحة عـن ايقـاف نقــل الصـلاحيات الـى المحافظــات ووجــهـ

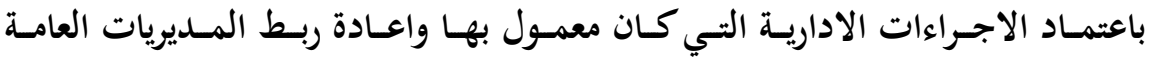

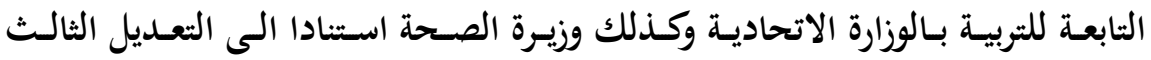

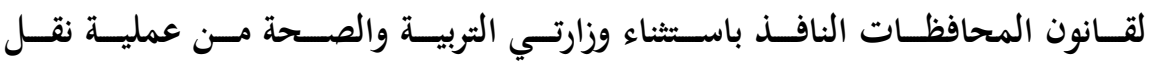
الصلاحيات (^) 
اذا يتضــح ممــا تقــدم رغسم الابعـاد الايجابيسة والسـلبية لعمليسة نقـل الصـالاحيات

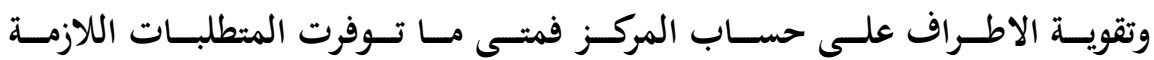

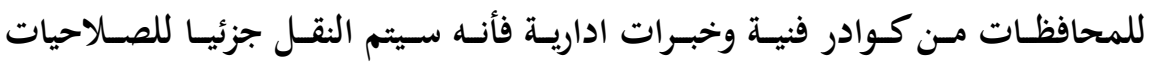

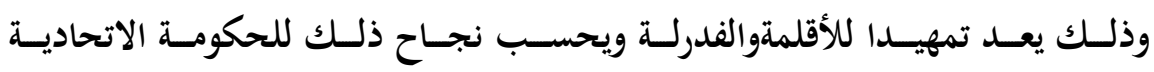
سياسـيا لان العـراق حاصـل جمـع محافظـات ورئسيس هـذه الحكومـة حصـلت كتلتسه.

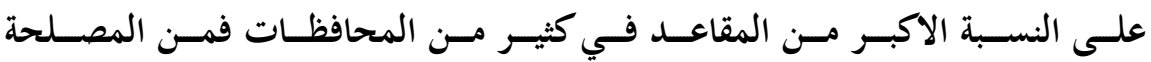

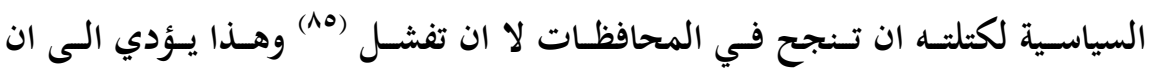

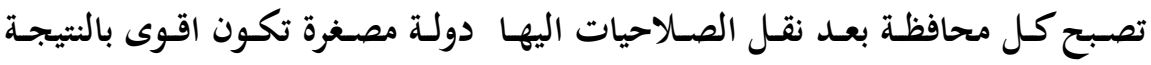

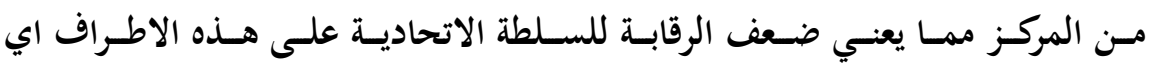
ضـعف المركـز وقـوة الاطـراف المحليسة فتثبـت بـذلك صسحة فرضسيتنا في تزايسد دور

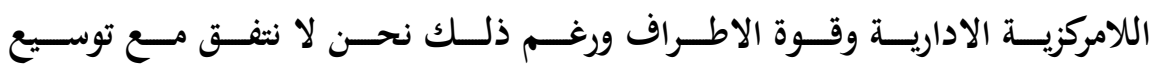
الصـالاحيات في ظـل هـذه الفتـرة كمــا يبسين الكاتسب الشـهير FriedRiggs

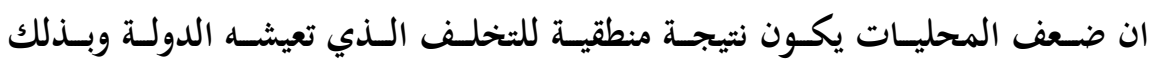

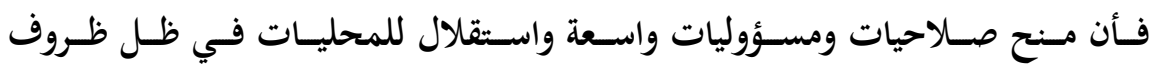

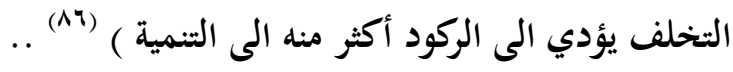
المطلب الثاني: تزايد قوة مركز السلطة الاتحادية

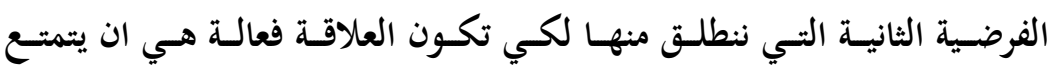

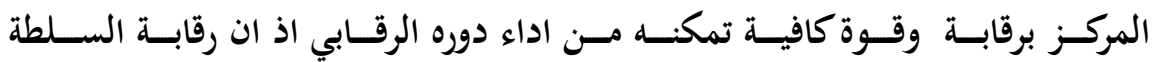

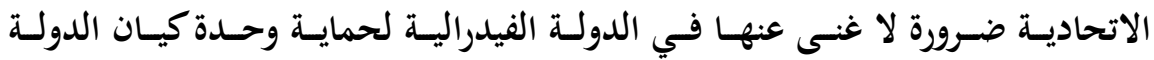

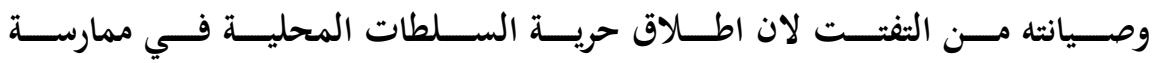

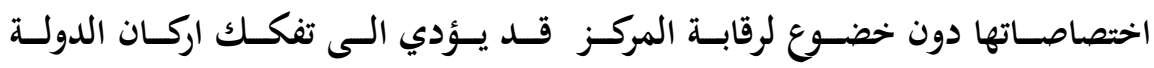

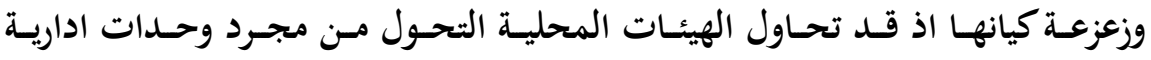

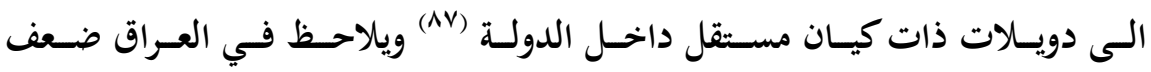

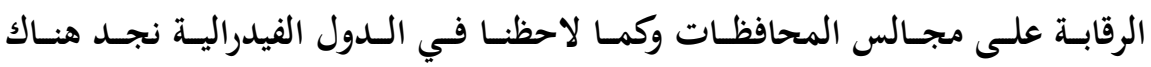


رقابـة مشــروعية تمـارس علـى الاقـاليم اي علـى مشـروعية القـوانين والقـرارات التسي

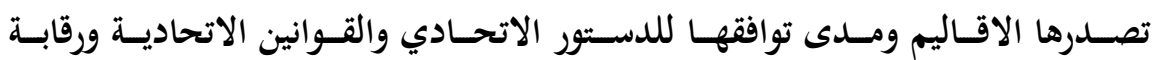

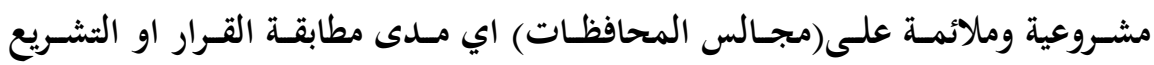

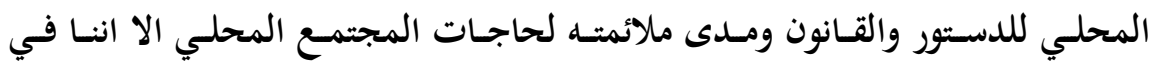

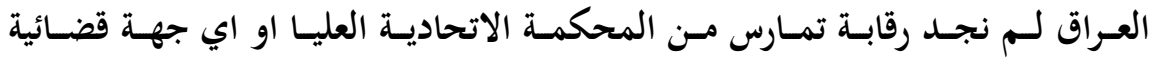
اتحاديـة علسى (اقلـيم كردسـتان) فاختصاصسها يقتصـر على الفصـل في المنازعـات

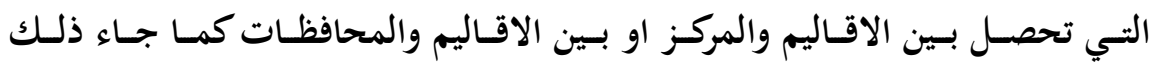

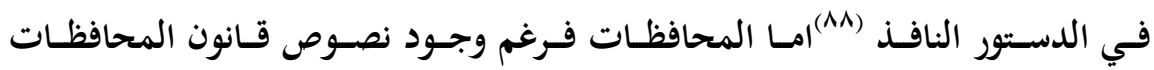

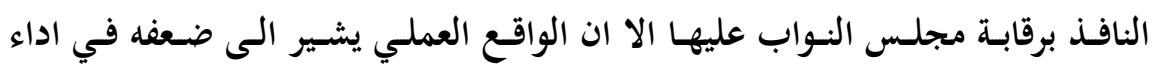

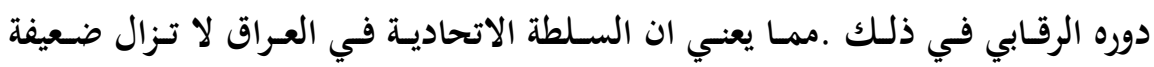

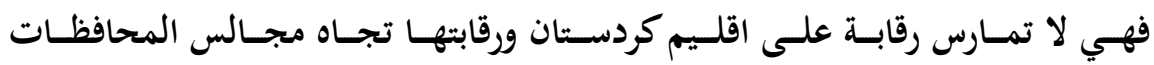
ليســت بالمسـتوى المطلـوب ومسن ثـم فأنسه يجــب ان يتمتـع المركـز بقـوة لا تصـل

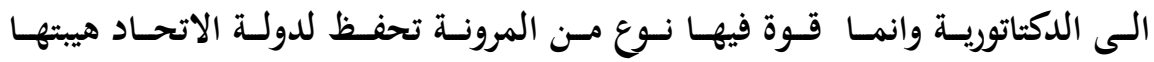

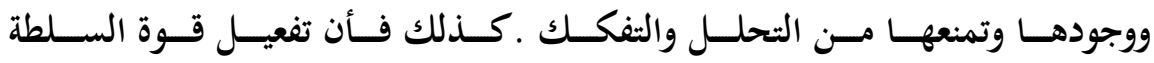

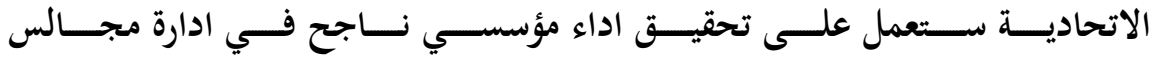

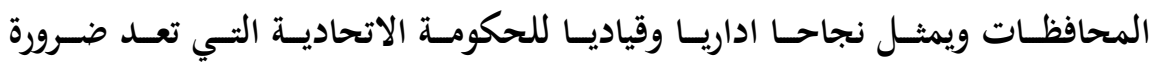
اساسـية لأسـباب عديــدة ومنهــا تـأثيرات المتغيـرات السياسـية المحيطـة بــالعراق

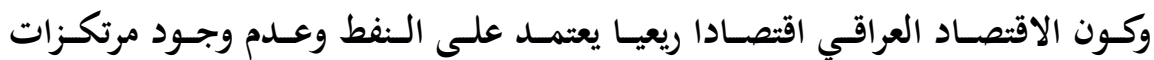

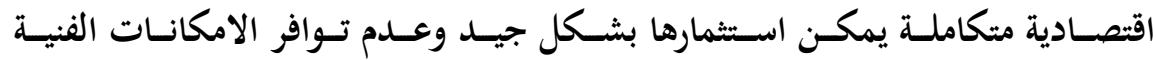

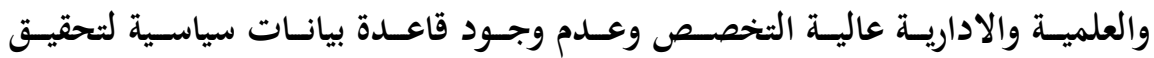
التنميـة المحليسة وهـذا كلـه لا يمكـن تحقيقهـه دون وجـود دور للمركـز الـذي يمتلـك

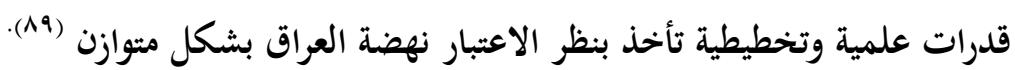




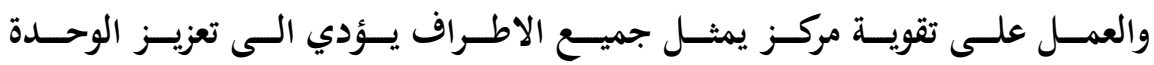

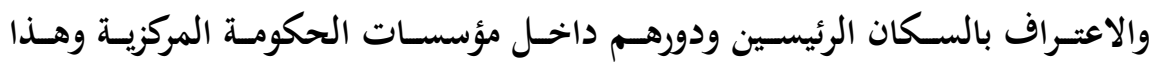

$$
\text { (a.) - : يمكن ان يشمل }
$$

اولا - تعريـف الدولـة او المجتمـع ككـل باسـتخدام رمسوز مقبولـة وطنيـا كـالحقوق ،

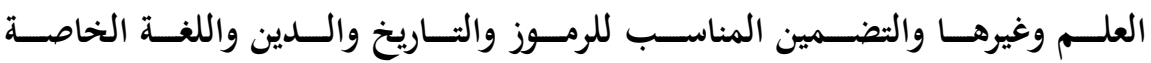
بالسكان المحليين وعيرهان. ثانيـا-تشــيع بـرامج وطنيـة تتبناهـا الحكومسة الاتحاديـة مثـل سـوق مشـترك او نظـام وطنسي للرعايـة الصـحية او مخططط وطنسي لرواتسب التقاعـد التـي يراهـا الجميـع انها مشاريع وطنية موحدة ذات منفعة متبادلة .

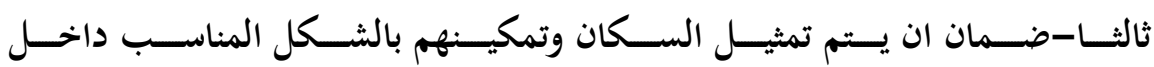

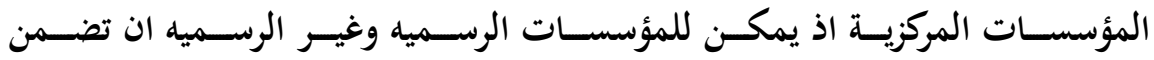
وجسود تمثيـل نسـبي لمختلـف المجموعـات في تركيبـة الحكومسة والخدمـة المدنيسة والجيش او في حالة تشكيل حكومة مشتركة عن طريق التفاوض . رابعـا- حمايـة الاقليـات داخـل الوحسدات المكونسة اذ تمثـل حمايـة الاقليـات داخـل

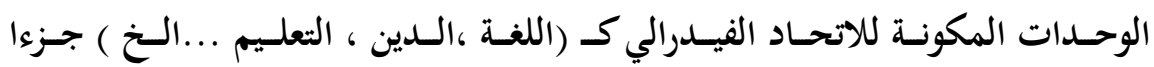
من توازن الحقوق واشكال الحماية في هذا الاتحاد.

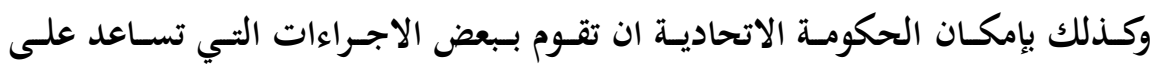

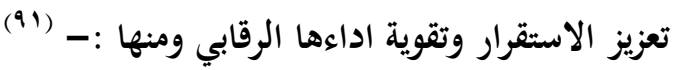

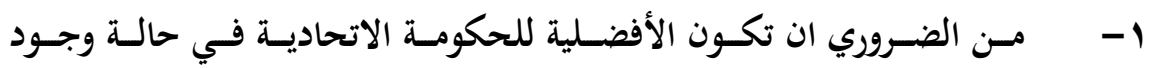

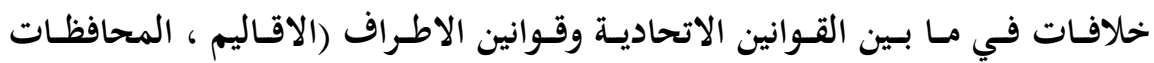
غير المنتظمة بإقليم ).

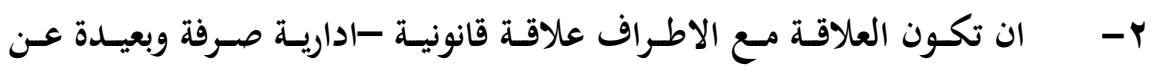
كل التأثيرات الايدلوجية القائمة على القومية او الدين او العرق او الطائفة . 


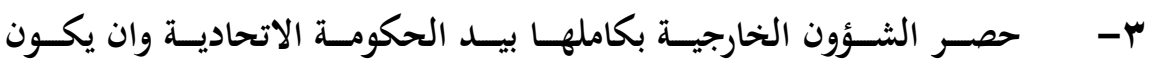

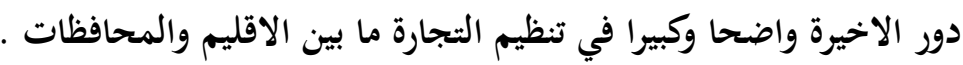

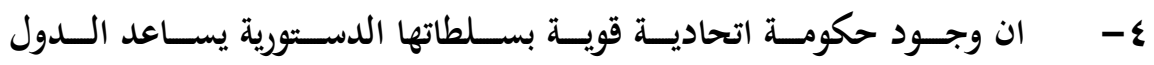
الاخــى على الحسد مـن النشـاطات غيـر الدستورية التـي تمارسـها بعض الممثليـات

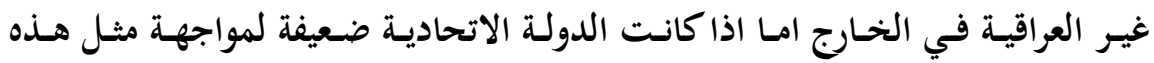

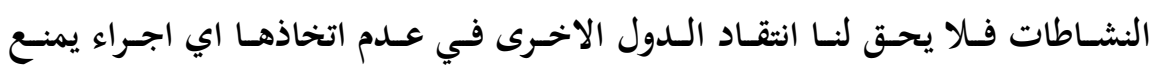

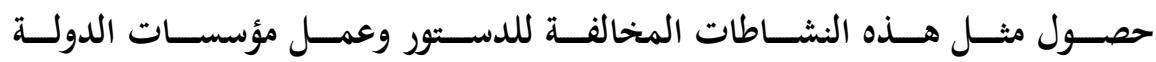

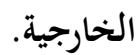

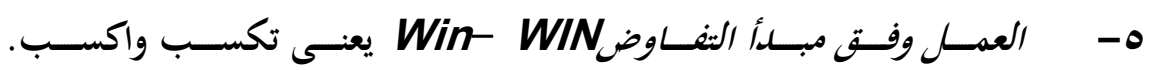

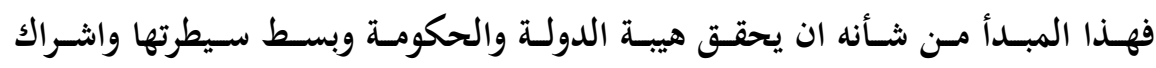

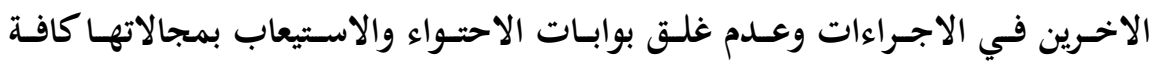

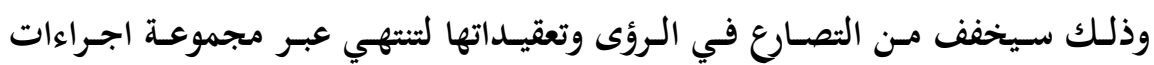

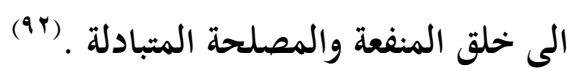

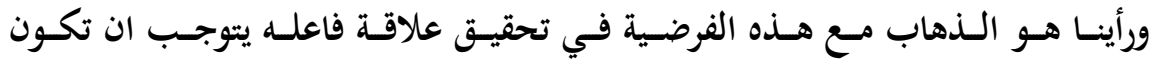

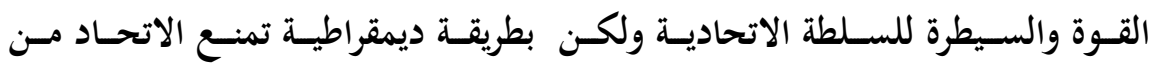

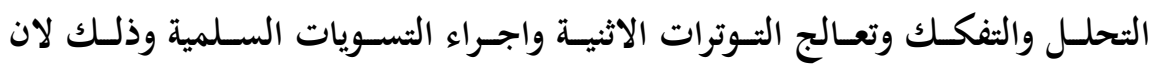

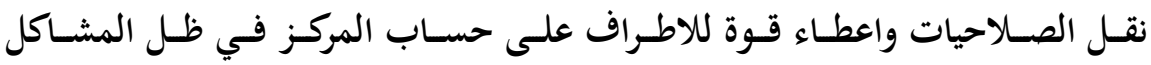

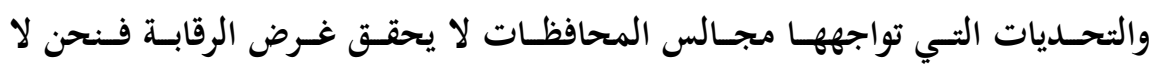

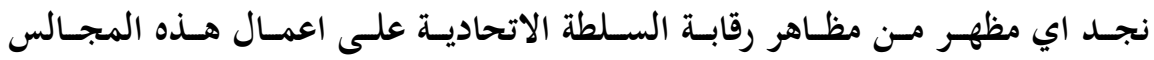

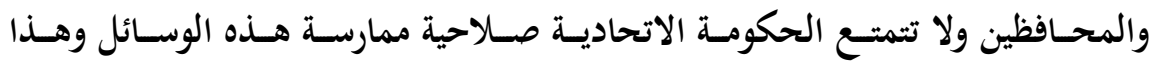

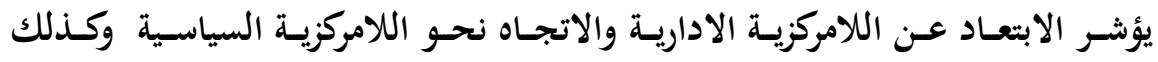
التفـويض والنعـاون المؤسسـاتي قــد يحقـق نتسائج مرضسية الا ان في الوقـت الحاضـر

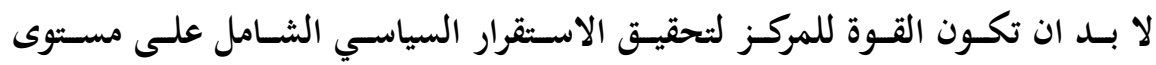

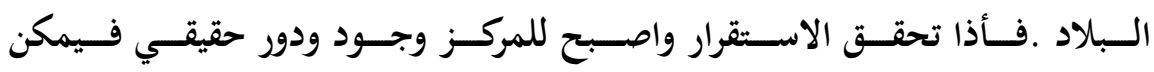


الحسـيث عـن توسـيع ونقـل للصــلاحيات السى المحافظــات غيـر المنتظمسة بـإقليم

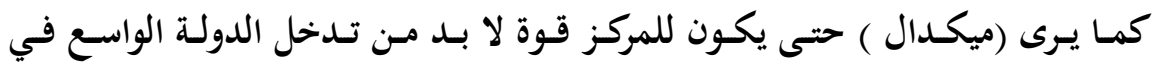

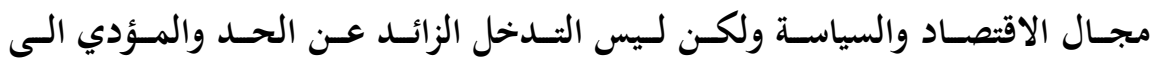

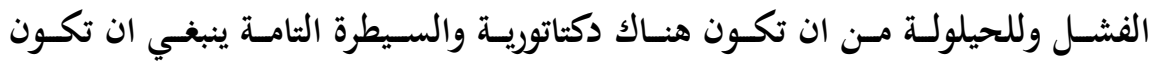

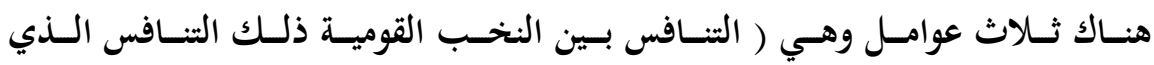

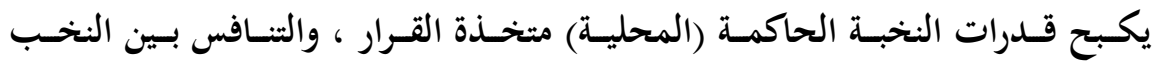

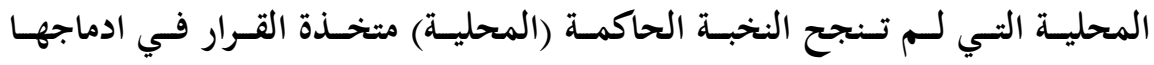

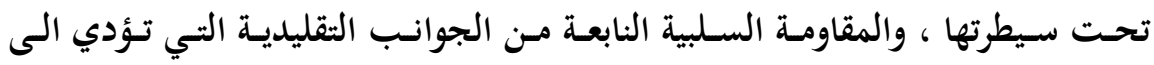

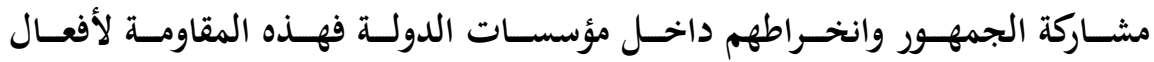
الحكومسة علـى المسـتوى المحلـي تمثـل قــوة دعـم للحكومسة الاتحاديسة ولا سـيما

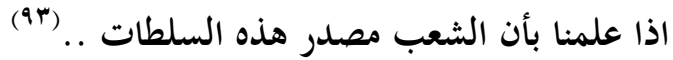

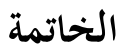

في خاتمة بحثنا وعبر ما تضمنه من مبحثين الاول منها كان في انماط علاقات التفاعل والثاني في مستقبل العلاقة التفاعلية وجدأن السلطة الاتحادية من مبادئ التنظيم السياسي الذي يسمح للحكومات المحلية ان تتحد تحت حكومة مشتركة في حين تحتفظ بباقي سلطاتها ووحداتها وتختص بما هو سيادي وما عداه يترك لهذه للأطراف

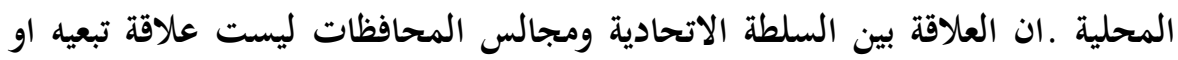
خضوع وانما علاقه تحكمها الرقابة والثعاون والتنسيق وتداخل في النصوص الدستورية والقانونية كما تم بيانها.وان اعطاء السلطة الاتحادية الحق في الرقابة على الحكومات المحلية يأتي لضمان تحقيق المصلحة العامة والحفاظ على الوحدة السياسية والقانونية

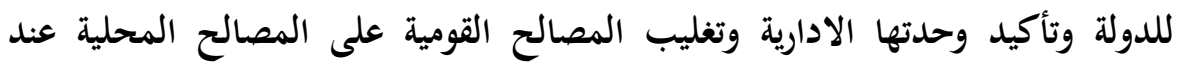
تعارضها والتنسيق بين الهيئات اللامركزية على مستوى الدولة ولحماية حقوق وحريات المواطنين من تعسف السلطات تجاههم . وتوصلنا الى اهم الاستنتاجات والتوصيات وهي كالاتي :- 
1- - انعـدام رقابـة السـلطة الاتحاديـة على مجـالس المحافظـات استينادا الى المـادة

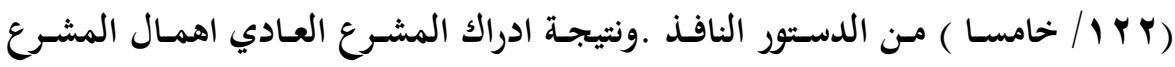

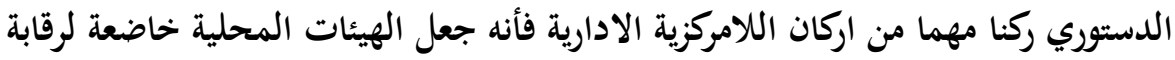
مجلس النواب ويعود ذلك الى التخوف من عودة الاستبداد في حال تقوية دور السلطة

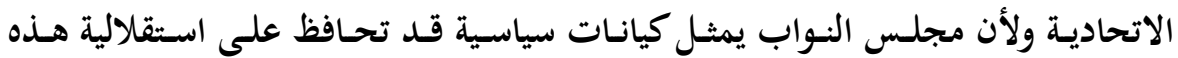
المجالس لما لديها من اعضاء ممثلين لأبناء محافظاتهم . r - - ان الواقع العملي لمجالس المحافظات غير المنتظمة باقليم في ظل التشريعات

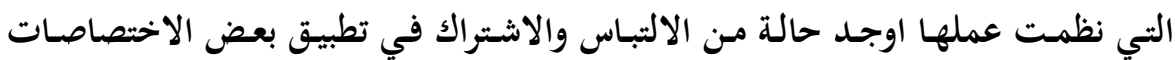
المتعلقة بعمل هذه المجالس وهو مايسمى بتداخل الاختصاصات . r- - ان مستقبل العلاقة الثفاعلية يأخذ جانبين (قوة الاطراف المحلية على حساب

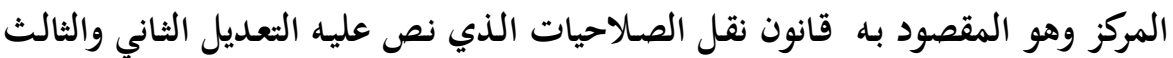

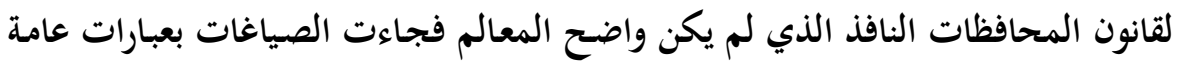
وغيـر محسددة فلـم يعـرف القـانون المقصـود بالسياسـة العامـة للـوزارة ولهم يحـدد طبيعـة العلاقات القانونية وحدودها بين الهيأة التنسيقية العليا للمحافظات والهيأة التنسيقية التي ينبغي تشكيلها في كل محافظة وبين مجالس المحافظات والدوائر التي نقلت صلاحياتها والوزارات الاتحادية وديوان المحافظة ـوجانب قوة مركز السلطة الاتحادية . ثانيا - التوصيات

1- سن قانون مجلس الاتحـاد المعطل تنفيذا للمـادة (07) من الدستور النافذ ، ومنحسه صـلاحيات رقابيـة تجـاه مجـالس المحافظـات، لا سـيما انه سيضـم ممثلـين عـن

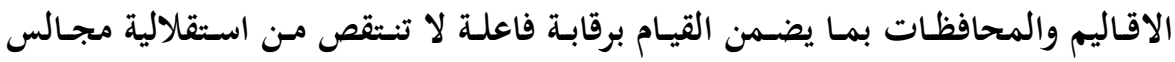




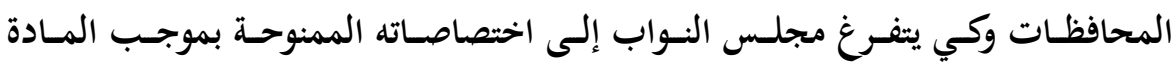

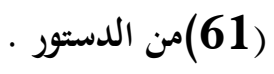

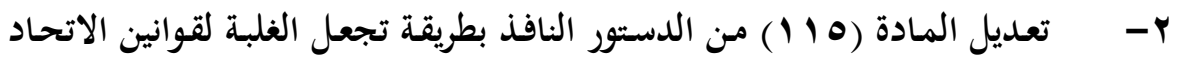

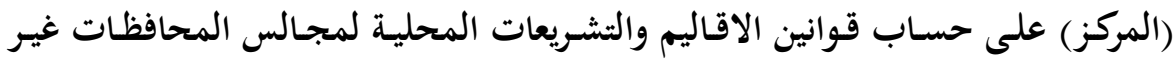

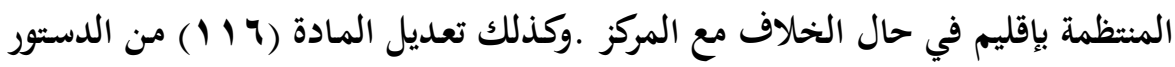

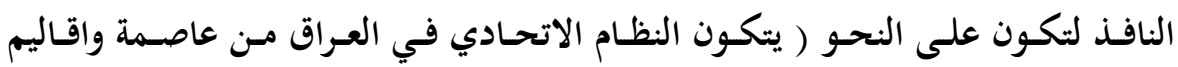
ومحافظات ويتم توزيع السلطات الاتحاديـة بين الحكومـة المركزيـة وحكومـات الاقـاليم

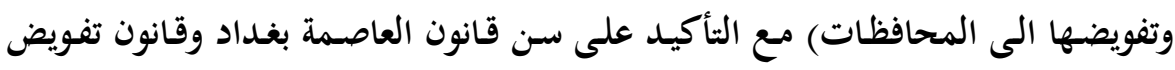
الصلاحيات في ذلك .

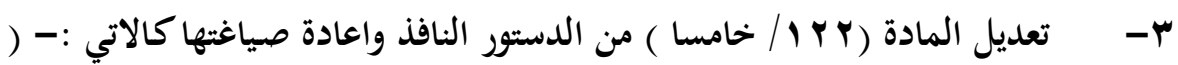

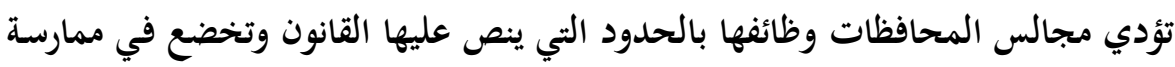

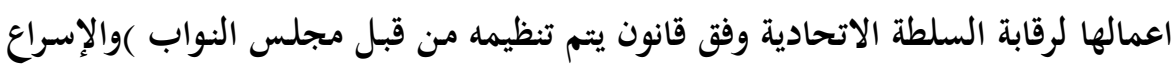

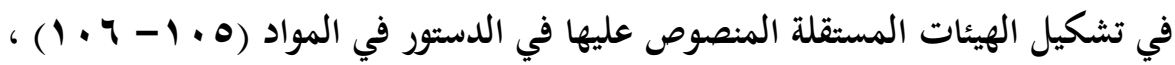

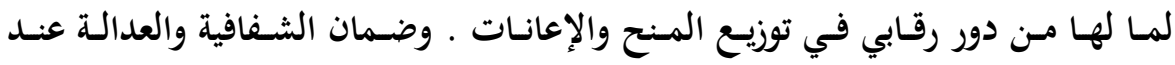
تخصيص الأموال لحكومات الأقاليم والمحافظات غير المنتظمة في إقليم

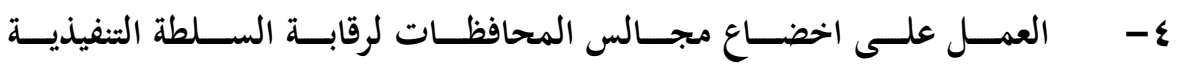
الاتحادية(مجلس الوزراء ) كونه السـلطة الاعلى في الدولة واعطاءه صـلاحيات رقابيـة واسعة تضمن الحفاظ على وحده الدولة وسلامتها القانونية والسياسية .وان تكون القوة لمركز السلطة الاتحادية في الوقت الحاضر بسبب مشاكل عدم الاستقرار والفساد بلدماد وسافة

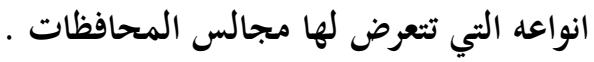

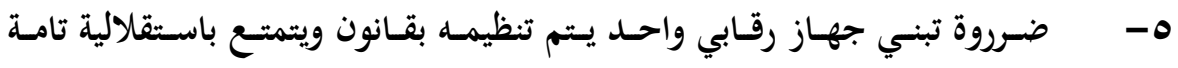

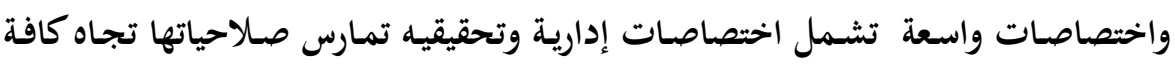

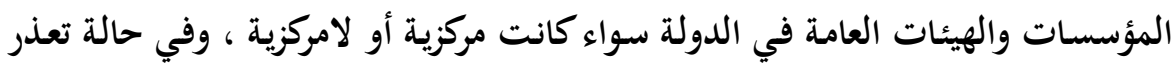




\section{إنشاء جهاز رقابي واحد شامل ، نرى ضرورة التنسيق بين الهيئات الرقابية الموجودة قدر الإمكان بما يضمن سير عمل مجالس المحافظات ...}

\section{Summary}

The local authority represented by the Provincial Council and the administrative units thereof has legislative and supervisory functions which are in the administration and supervision of the local public utilities as provided for by the laws in force. The subject of the interactive relationship between the federal authority and the provincial councils not organized in one of the main problems that accompanied the emergence and application of decentralized system Iraq after 2003, which began since the writing of the Constitution in force for the year 2005 and the law of the provinces No. 21 of 2008 This law has been subjected to political recordings that eventually led to the appearance of this consensus image. The weakness of the legislative formulation was one of the reasons for this in the enactment of inaccurate laws that resulted in defining the form of the relationship in three axes (supervision cooperation - overlap) in the powers and powers conferred by the Constitution and the Provincial Law The control is the means and practice carried out by the federal authority for the purpose of achieving the planned goals and maintain the unity of the political and legal state, cooperation is the best way to achieve the objectives of the general policy of the state, and overlap is a state of confusion and despair RAC in the application of some of the terms of reference for the work of the federal authority and the local authority.

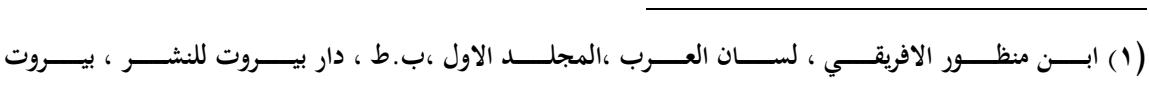

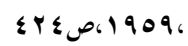

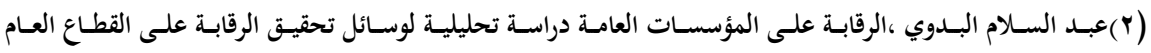

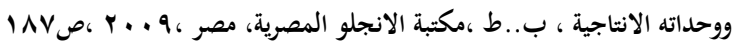




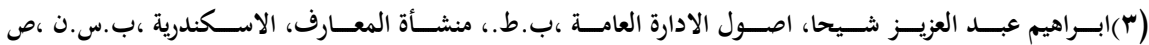

(") السلطة المحلية: تعني المجلس المحلي والتشكيلات الادارية والاجهزة التابعة له.

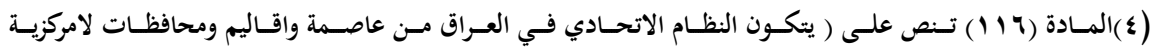

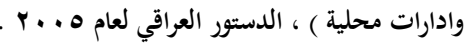

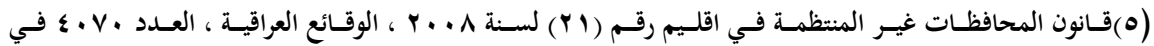

$$
r \cdot \Lambda / r / \mu r
$$

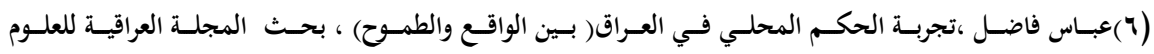

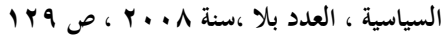

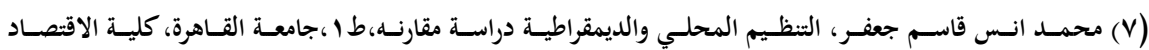

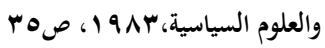

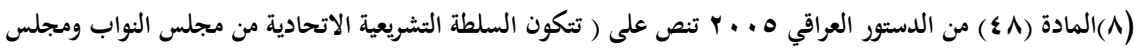
الاتحاد )

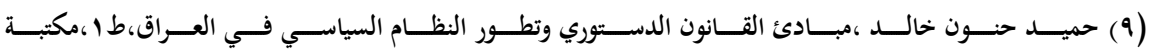

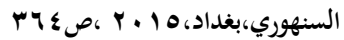

( • (1) المادة (ץ/ثانيا ) من قانون المحافظات غير المنتظمة في اقليم (يخضع مجلس المحافظة والمجالس المحلية لرقابة

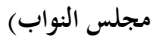

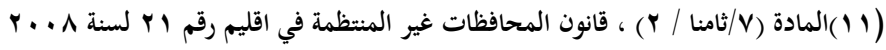

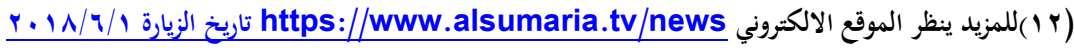

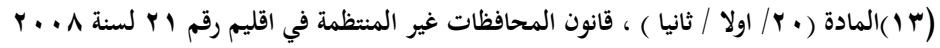

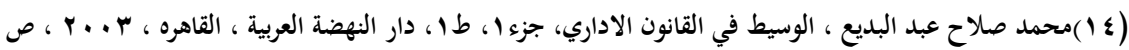

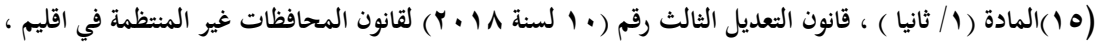

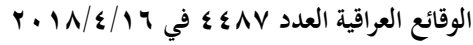

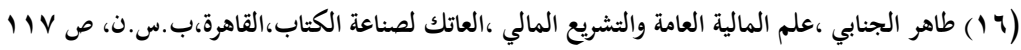

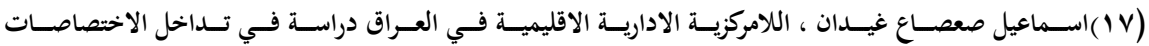

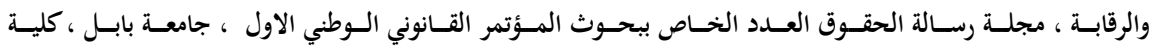

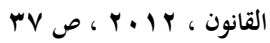

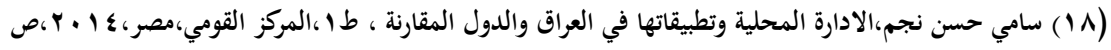




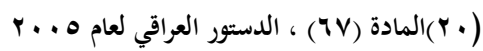

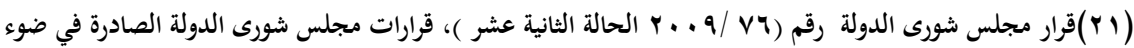

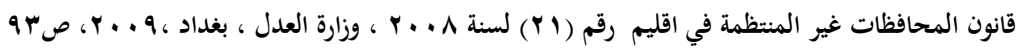

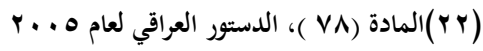

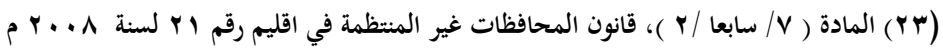

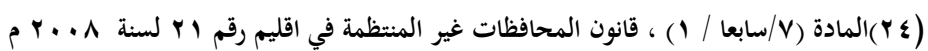

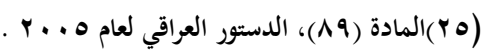

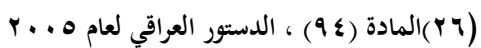
نجيب خلف احمد، محمد علي جواد كاظم، القضاء الاداري ، الجامعة المستنصرية ، كلية القانون ، • 1 • Y ) ص ص

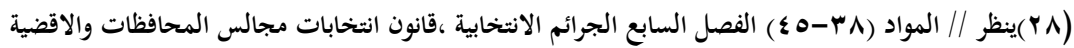

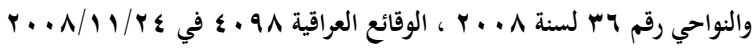

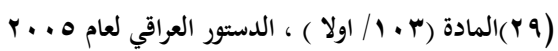

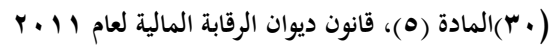

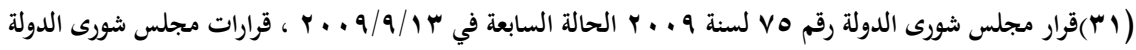

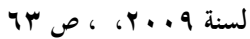

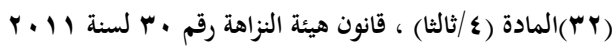
(ب) كلاويش مصطفى ابراهيم ، نظام المفتش العام وتطبيقه في العراق ، اطروحة دكتوراه غير منشورة ، كلية الحقوق ،

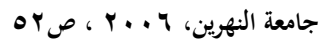

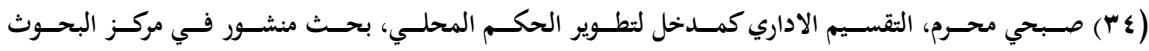

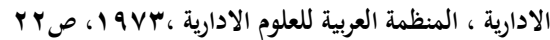

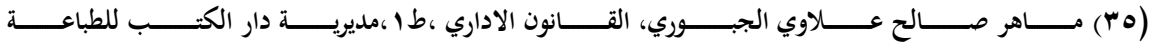

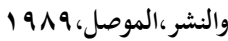

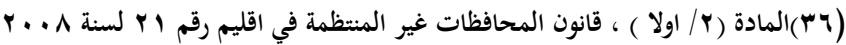
*نتص المادة (با//اولا )من الدستور النافذ على (يعد هذا الدستور القانون الاسمى والاعلى في العراق، ويكون ملزما في انحائه كافة وبدون استثناء )

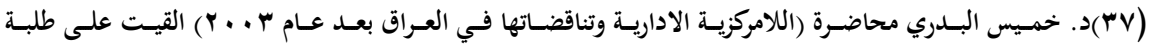
الدراسـات العليــ (الماجسـتير)، كليــة العلـوم السياسـية/ جامعـة بغــداد، فــرع الحكومـات والادارة المحليـة ، يـوم

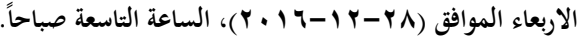




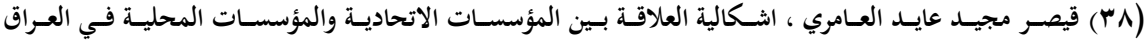

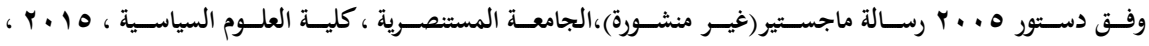

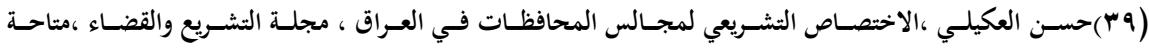

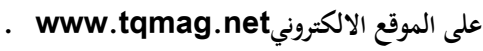

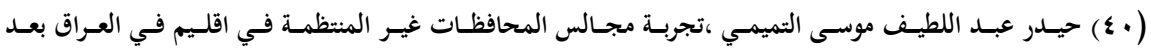

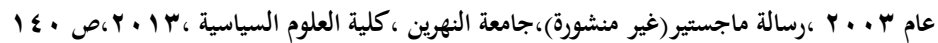

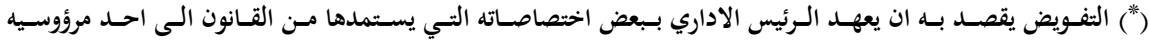

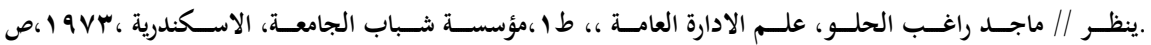

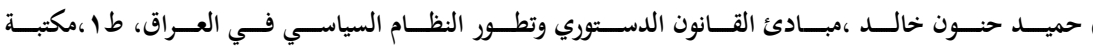

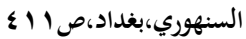

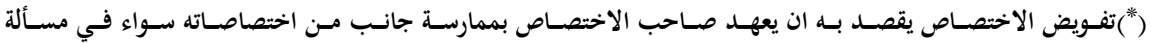

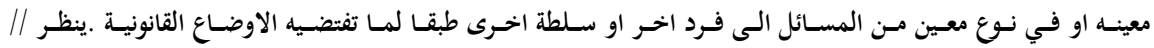

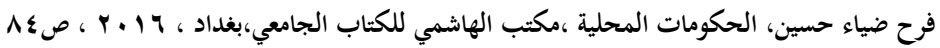

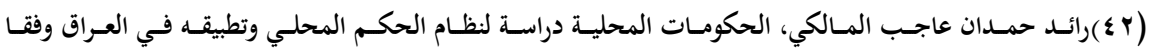

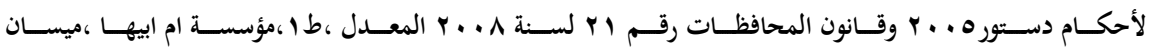
rNO ص, r. 106

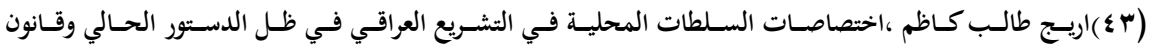

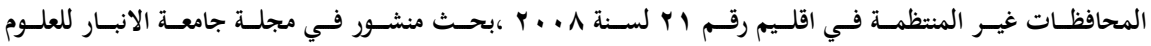

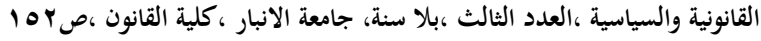

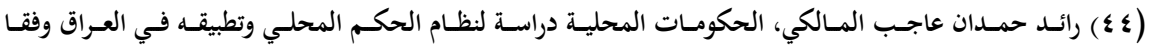

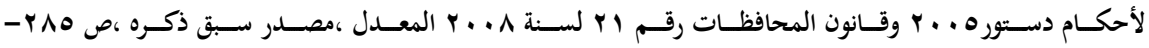

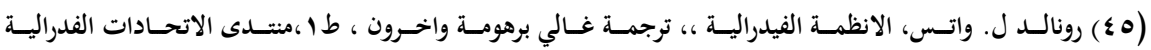
or ص، r...7،

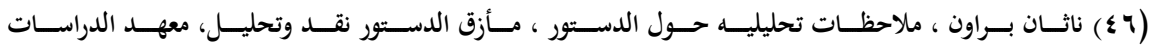

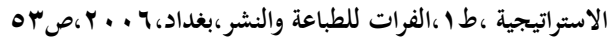

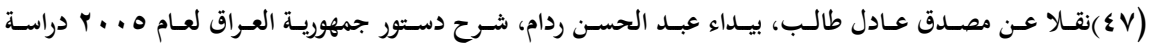

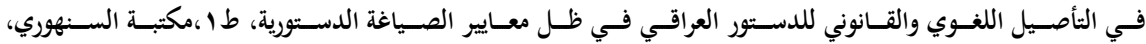




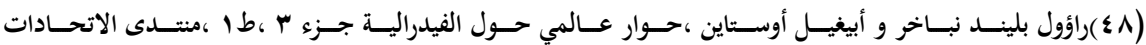

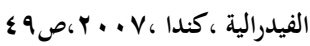

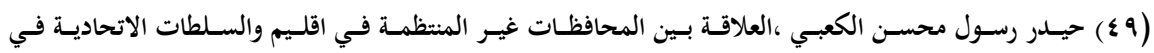

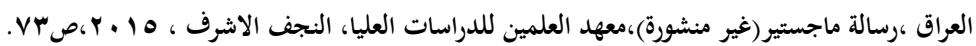

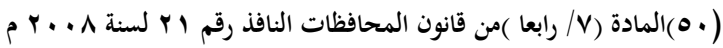

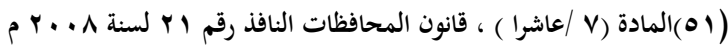

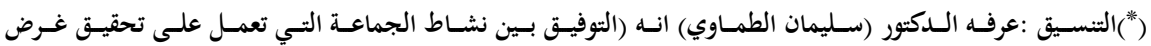

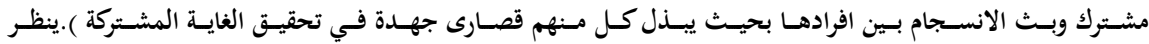

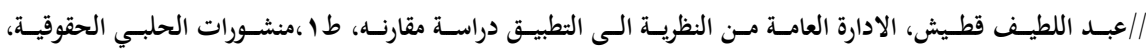

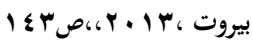

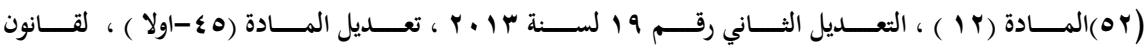

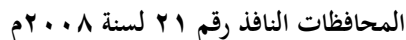

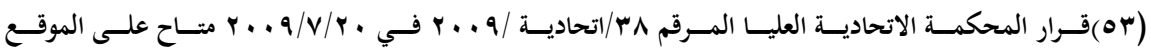
www. iraqja.iq. الالكتروني

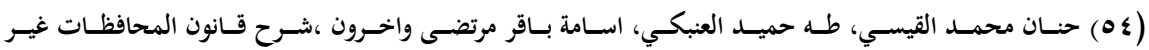

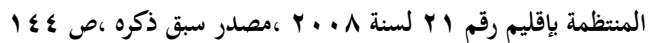

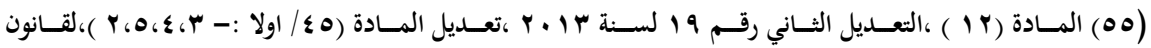

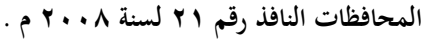
(7) علـي هـادي حميـدي الشـكراوي ،علاقـة السـلطة الاتحاديـة بالسـلطات المحليـة وفـق دسـتور العــاق لعـام

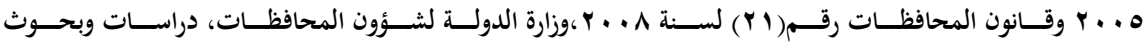

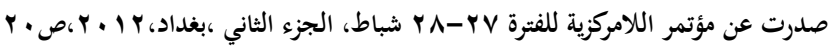

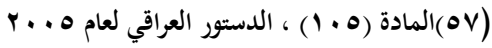

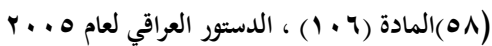

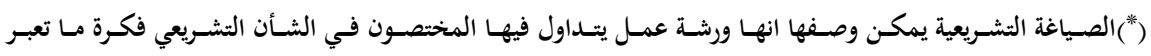

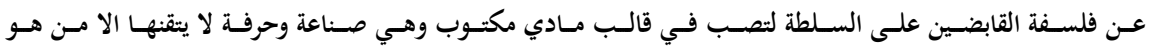

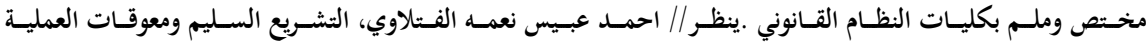

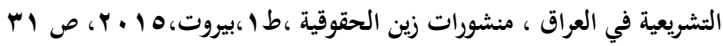

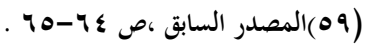

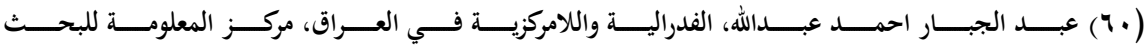

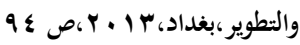




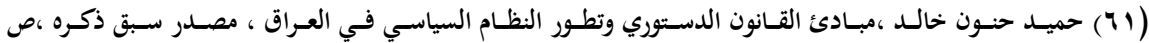

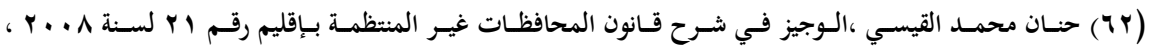

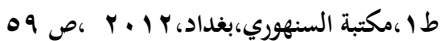

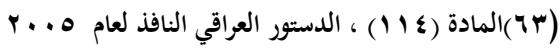

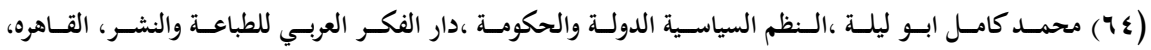

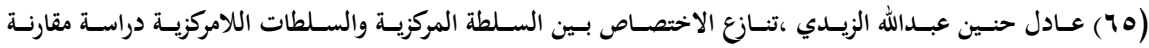

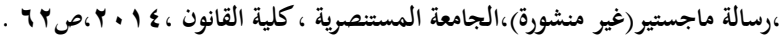

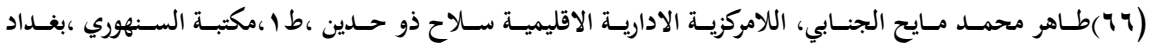
ar ص r. r r v

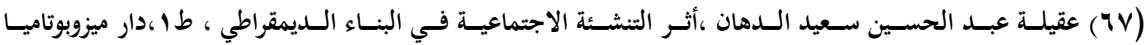

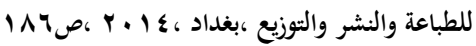

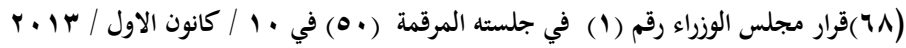

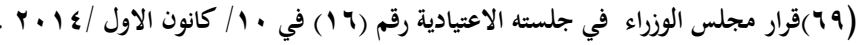

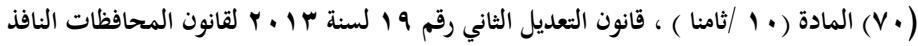
ملتقـى النبـأ الاسـبوعي ، نقـل الصـلاحيات مـن المركسز الـى المحافظـات ، متساح علـى الموقـع الالكترونسي r Https://annabaa.org

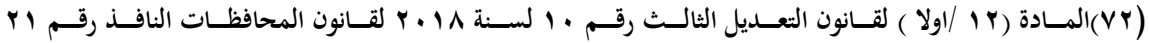

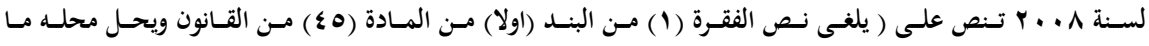

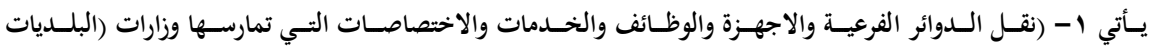

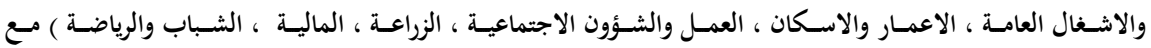

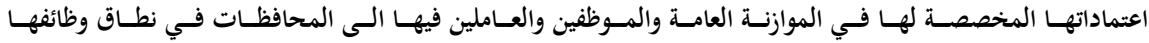

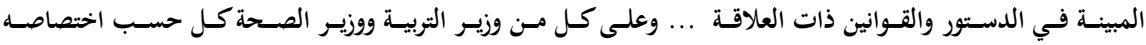
تفويض الصلاحيات اللازمة والتي تصدر بتعليمات من مجلس الوزراء ) . (VT)

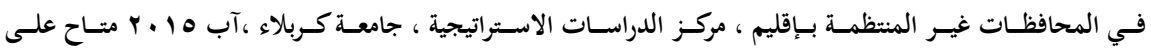

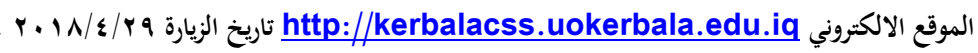

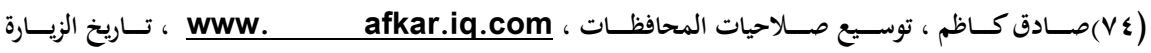




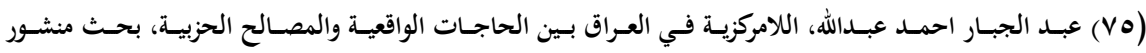

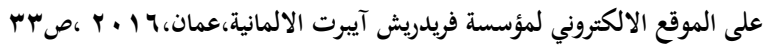

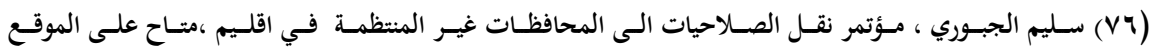

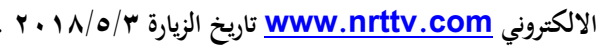

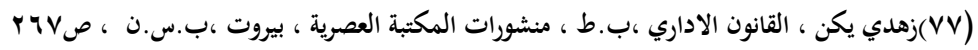

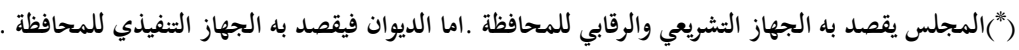

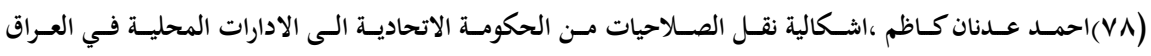

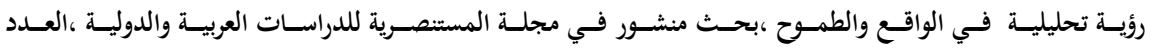

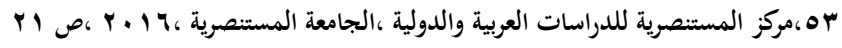

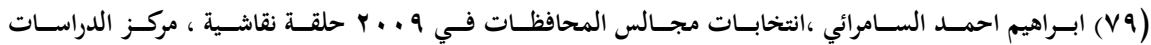

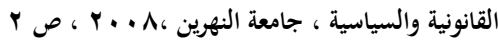

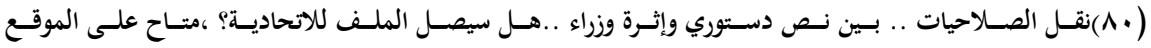
الالكتروني

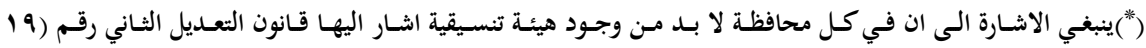

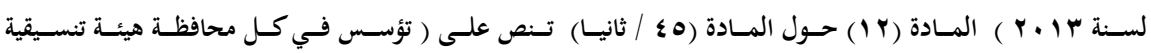

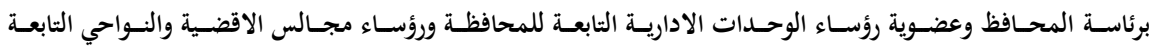

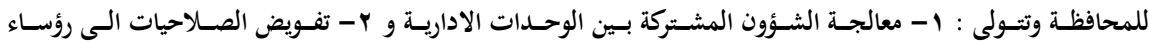

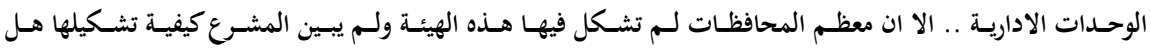

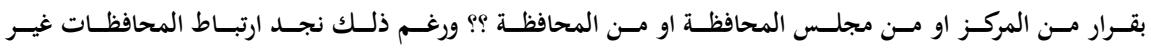
المنتظمة باقليم بالهيئة العليا التنسيقية بين المحافظات.

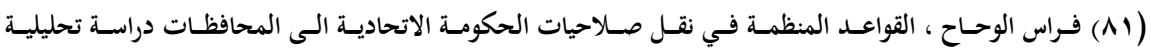

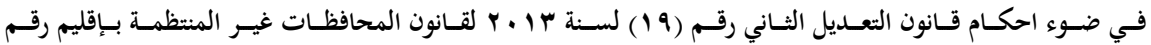

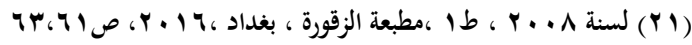
فو (Ar) r.http://newsabah.com علم (NT)

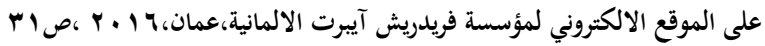

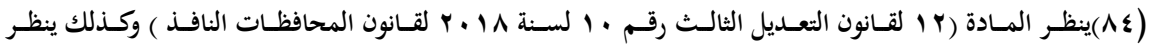

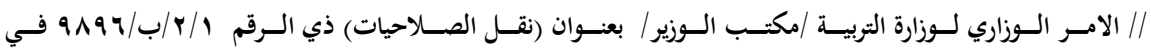

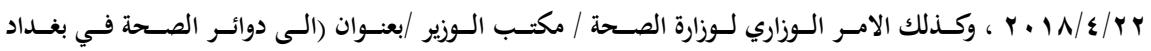

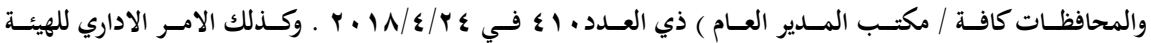

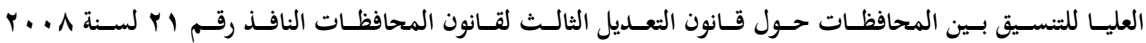




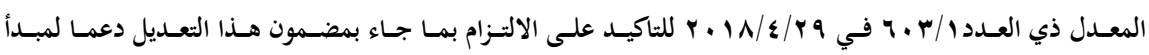

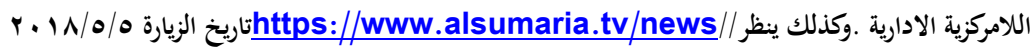

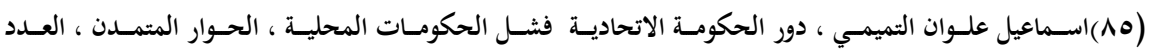

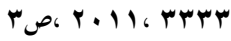

( ) (1) محمد محمود الطعامنة ،نظم الادارة المحلية في الوطن العربي ،الملتقى العربي الاول ، المنظمة العربية للتنمية

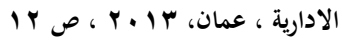

محمــد حســـن (Av)

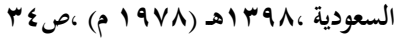

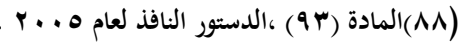

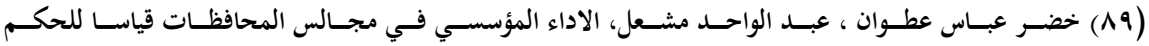

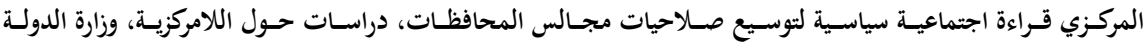

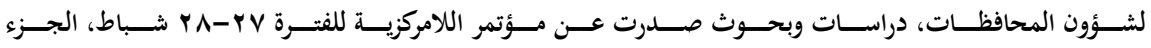

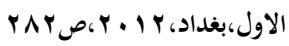

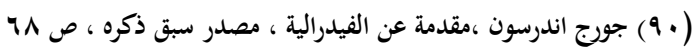

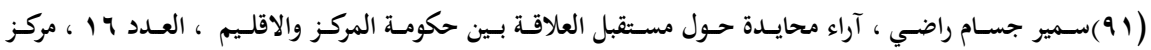

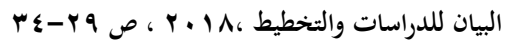

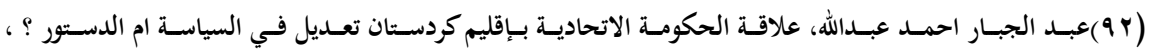

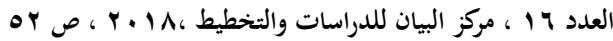

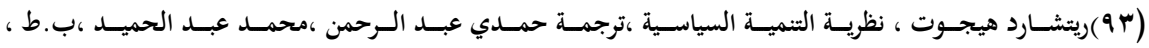

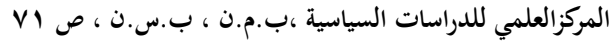

